CíNTIA LUÍZA DA SiLVA LUZ

\title{
ANACARDIACEAE R. BR. NA FLORA FANEROGÂMICA DO Estado de São Paulo
}

\section{ANACARDIACEAE R. BR. IN THE PHANEROGAMIC FLORA OF THE São Paulo State}

Dissertação apresentada ao Instituto de Biociências da Universidade de São Paulo, para a obtenção de Título de Mestre em Botânica.

Orientador: Prof. Dr. José Rubens Pirani

São Paulo 2011 
Luz, Cíntia Luíza da Silva

Anacardiaceae R. Br. na Flora Fanerogâmica do Estado de São Paulo.

Número de páginas: 94

Dissertação (Mestrado) - Instituto de Biociências da Universidade de São Paulo. Departamento de Botânica.

1. Anacardiaceae 2. Flora 3. Estado de São Paulo 4. Sistemática Vegetal I. Universidade de São Paulo. Instituto de Biociências. Departamento de Botânica.

\section{Comissão Julgadora:}

$\operatorname{Prof}(a) . \operatorname{Dr}(a)$.

$$
\text { Prof(a). Dr(a). }
$$

Prof. Dr. José Rubens Pirani

Orientador 
À minha família 
"Mesmo que eu fale em línguas, a dos homens e dos anjos, se me falta o amor, sou um metal que ressoa, um címbalo retumbante.

Mesmo que tenha o dom da professia, o saber de todos os mistérios e de todo o conhecimento, mesmo que tenha a fé mais total, a que transporta montanhas, se me falta o amor, nada sou."

1 Coríntios 13: 1-2. 


\section{AGRADECIMENTOS}

Ao professor Dr. José Rubens Pirani, cuja orientação e dedicação contribuiu para a realização deste trabalho. Seu comprometimento e amor pela botânica é uma inspiração na busca do conhecimento.

À CAPES, pela bolsa de mestrado concedida nos primeiros meses de desenvolvimento deste trabalho.

À Fundação de Amparo à Pesquisa do Estado de São Paulo (FAPESP processo 2009/01612-4), pela concessão da bolsa de mestrado e da reserva técnica que foram significativas para o desenvolvimento e conclusão deste estudo.

Ao Departamento de Botânica e ao Programa de Pós-Graduação em Botânica do IBUSP, pela excelência no curso de pós-graduação.

Aos curadores dos herbários, pela disponibilização de seus acervos, solicitude e assistência na localização e empréstimos de materiais.

Aos curadores dos herbários internacionais, que gentilmente enviaram fotos dos materiais-tipo.

Aos gestores das Unidades de Conservação do Parque Estadual da Serra do Mar, núcleo Picinguaba e Curucutu, Parque Estadual de Campos do Jordão, Parque Estadual do Juqueri, Estação Experimental de Itapeva e Floresta Nacional de Capão Bonito, pela concessão da licença de coleta e auxílio logístico.

Ao Abel, pelo auxílio na separação de materiais de coleta e montagem das exsicatas.

À Viviane Jono, pela solicitude na separação de materiais, auxílio na solicitação de empréstimos e pelo convívio agradável.

Aos colegas pesquisadores do laboratório de Sistemática Vegetal: Benoit, Carolina, Fabiana Firetti, Gustavo, Herbert, Jenifer, Juliana El Ottra, Juliana Lovo, Juliana Rando, Marcelo Devecchi e Paulo Gonella, pelo auxílio nas viagens de coleta, pela companhia nas visitas a herbários, obtenção de espécimes e fotografias.

Ao Cláudio Nicoletti e Mariana Saavedra, pela hospedagem quando em visita ao herbário $\mathrm{RB}$, por toda a atenção dispensada, ocasião na qual me senti em casa.

À Renata Souza de Oliveira, pelo auxílio na confecção dos mapas de distribuição geográfica.

Ao Benoit, por ser solícito na elucidação de algumas dúvidas.

Ao Anselmo, pelas viagens de campo e amizade.

À Juliana El Ottra (Juzinha), por compartilhar todos os momentos da realização deste trabalho. Pelo companheirismo, amizade, apoio, grande e inestimável auxílio nas coletas e sobremaneira a empatia. 
À Juliana Lovo, pela amizade incomensurável e palavras de incentivo nos momentos difíceis.

À Maria Fernanda Calió, pela amizade, apoio constante e orientação em todas as fases da execução deste trabalho.

Aos docentes, técnicos e colegas do laboratório de Sistemática Vegetal que contribuíram direta ou indiretamente para a minha formação e conclusão desta dissertação de mestrado.

A todos os meus amigos, que torceram por mim, deram-me apoio e principalmente me fazerem sentir uma pessoa querida.

Aos meus pais, José e Elisabeth, pelo amor, apoio sem limites, por acreditarem em mim e principalmente se dedicarem a facilitar a minha vida. Ao meu irmão, Tiago, pela amizade e aos meus queridos avós, Antenor e Clotilde, pelo carinho.

Ao meu primeiro, grande e sempre presente, amor, Luciano, pelo auxílio inestimável na execução deste trabalho, principalmente nas viagens de coleta, auxiliando como motorista, mateiro e um quase "parataxonomista". Pelo amor, paciência, apoio e por me fazer uma pessoa mais feliz. 
ÍNDICE

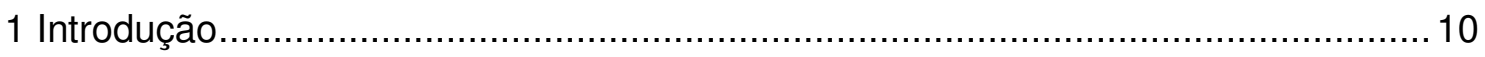

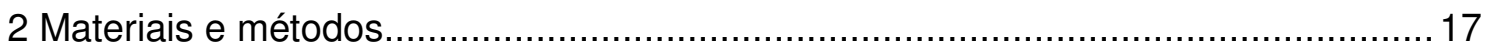

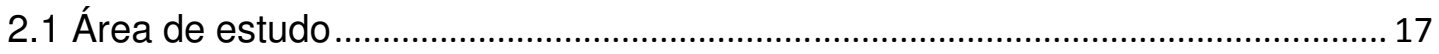

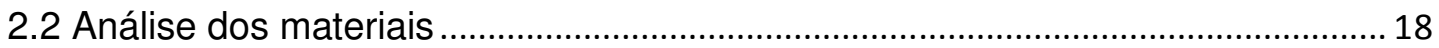

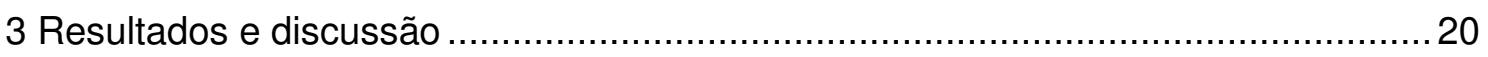

3.1 Flora Fanerogâmica do Estado de São Paulo ........................................................ 20

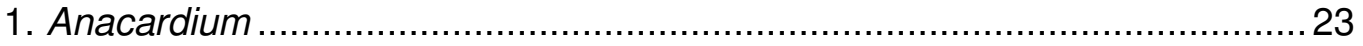

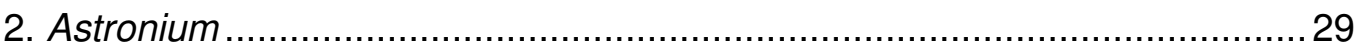

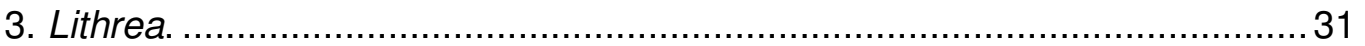

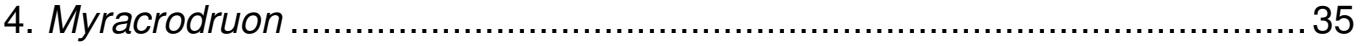

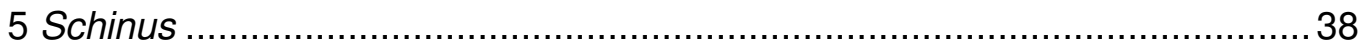

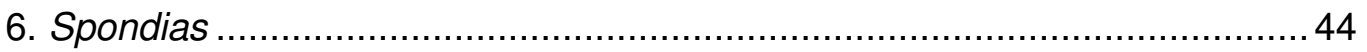

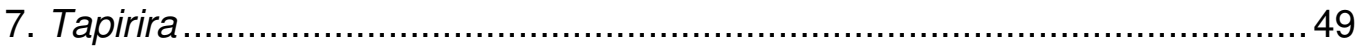

3.2. Estado de conservação e distribuição geográfica das espécies ...........................54

3.3. Diversidade sexual e padrões fenológicos gerais das Anacardiaceae de São Paulo .67

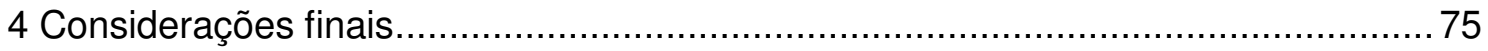

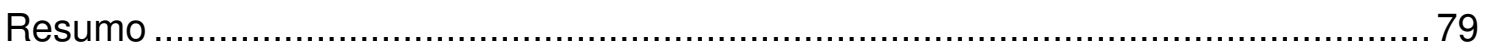

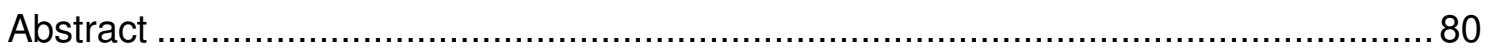

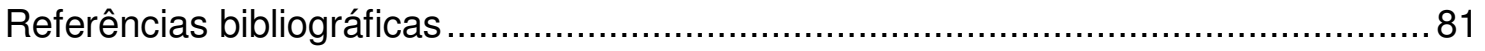




\section{LISTA DE TABELAS}

Tabela 1: Número de espécimes estudados de Anacardiaceae do Estado de São Paulo, atualizados quanto à determinação e fotografados em cada herbário brasileiro visitado. 19

Tabela 2: Espécies candidatas à lista de espécies ameaçadas. .57

Tabela 3: Distribuição das espécies de Anacardiaceae de São Paulo nas formações vegetacionais naturais e em áreas antropizadas do Estado. .65

Tabela 4: Sistemas sexuais em Anacardiaceae. Dados provenientes do estudo das Anacardiaceae do Estado de São Paulo (ø) e dados provenientes da literatura $(\bullet)$....74 Tabela 5: Registros de floração (ロ) e de frutificação (•) das espécies de Anacardiaceae do Estado de São Paulo baseados nas coleções de herbário analisadas. 74

\section{LISTA DE FIGURAS}

Figura 1: Prancha de ilustrações 26

Figura 2: Prancha de fotografias. 39

Figura 3: Prancha de ilustrações. 46

Figura 4: Prancha de fotografias. 48

Figura 5: Mapa de distribuição de Lithrea brasiliensis $(\mathbf{\Delta})$ e de Lithrea molleoides $(\bullet)$ no Estado de São Paulo. As populações de L. brasiliensis do Rio de Janeiro apresentam folhas obovadas com ápice truncado ou emarginado; enquanto os espécimes do sul do Brasil, Argentina e Uruguai possuem folhas geralmente oblongas com ápice mucronado. .56

Figura 6: Mapa de distribuição de Schinus engleri $(\bullet)$, S. terebinthifolius $(\bullet)$ e $S$. weinmannifolius $(\boldsymbol{\Delta})$ no Estado de São Paulo. 58

Figura 7: Mapa de distribuição de Astronium graveolens ( $\mathbf{\Delta}$ ), Myracrodruon urundeva

(匹) e Spondias mombin $(\bullet)$ 60 no Estado de São Paulo. 60

Figura 8: Mapa de distribuição de Anacardium humile (•) e Anacardium occidentale ( $\Delta$ ) no Estado de São Paulo. 64

Figura 9: Mapa de distribuição de Tapirira guianensis (•) e Tapirira obtusa ( $\mathbf{\Delta})$ no Estado de São Paulo.

Figura 10: Gráfico da distribuição das espécies de Anacardiaceae nas diversas formações vegetacionais naturais e em áreas antropizadas de São Paulo.

Figura 11: Número de espécies de Anacardiaceae por região brasileira. As áreas brancas em cada diagrama circular refere-se ao número de espécies regionais (não endêmicas do Brasil); as áreas cinza-claras expressam o número de espécies 
endêmicas da região e as áreas cinza-escuras expressam o número de espécies que também ocorrem em outras regiões brasileiras. Os círculos pretos indicam o número de espécies endêmicas compartilhadas pelas duas regiões conectadas por pontilhados brancos. As setas pretas ilustram os gêneros que possuem riqueza de espécies na região. Dados baseados em Silva-Luz \& Pirani 2010. Não foram considerados níveis infraespecíficos. 66 


\section{Introdução}

A família Anacardiaceae possui aproximadamente 81 gêneros e 800 espécies, presentes em ambientes secos a úmidos, principalmente em terras baixas nas regiões tropicais e subtropicais em todo o mundo, estendendo-se até regiões temperadas (Pell 2011). Nas Américas existem aproximadamente 32 gêneros nativos, sendo que $77 \%$ das espécies são endêmicas do continente americano e apenas os gêneros Antrocaryon, Campnosperma, Cotinus, Pistacia, Rhus, Spondias e Toxicodendron possuem representantes em outros continentes também (Terrazas 1999). No Brasil, estão catalogados 14 gêneros com 57 espécies de Anacardiaceae, sendo que 14 delas são restritas ao país (Silva-Luz \& Pirani 2010).

Trata-se de um grupo de plantas lenhosas resiníferas, cujas partes jovens exalam aroma e sabor característicos, semelhantes ao do fruto verde da manga (Mangifera indica L.), uma das espécies mais notórias da família. As folhas são simples ou compostas, e as flores são dialipétalas, isostêmones ou obdiplostêmones, com ovário súpero geralmente uni ou tricarpelar, mas unilocular e uniovulado, produzindo frutos carnosos ou secos unisseminados.

Diversas Anacardiaceae têm importância econômica por fornecerem frutos comestíveis, madeiras úteis ou espécies ornamentais. Do fruto do cajueiro (Anacardium occidentale L.) obtém-se a castanha de caju, enquanto o pedicelo floral espessado (hipocarpo ou fruto acessório) é comercializado in natura. Outros frutos de importância comercial ou regional incluem a manga (Mangifera indica L.), os cajás (Spondias spp.), o umbu (Spondias tuberosa Arruda) e a seriguela (Spondias purpurea L.). Schinus terebinthifolius Raddi, Schinus molle L. e Rhus succedanea L. são exemplos de plantas utilizadas na ornamentação de ruas e praças. Entre as espécies que apresentam madeira de boa qualidade estão o gonçalo-alves (Astronium fraxinifolium Schott ex Spreng.), o guaritá (Astronium graveolens Jacq.), a aroeira (Myracrodruon urundeuva Allemão), a aroeira-branca (Lithrea molleoides (Vell.) Engl.) e a braúna (Schinopsis brasiliensis Engl.) (Souza \& Lorenzi 2005).

Algumas espécies de Anacardiaceae têm uso na medicina popular brasileira pela potencial atividade antifúngica (Fenner et al. 2006). Aproximadamente 32 gêneros da família contêm espécies conhecidas que causam dermatites (Mitchell 1990). As dermatites podem ser causadas pela resina, sendo atribuídas principalmente aos compostos fenólicos e catecólicos ou à mistura destas substâncias, denominados lipídios fenólicos. As espécies mais estudadas, do ponto de vista químico, são Mangifera indica, Anacardium occidentale e algumas espécies de Rhus. A diversidade 
dos metabólitos e atividades biológicas tem justificado o enorme interesse no estudo desta família na busca de princípios bioativos (Correia et al. 2006).

Do ponto de vista ecológico, algumas espécies de Anacardiaceae são indicadas para reflorestamento, como o pau-pombo (Tapirira guianensis Aubl.), que é utilizado em programas de reflorestamentos ambientais, recuperação de áreas degradadas, em projetos de reposição de mata ciliar e estabilização de dunas (Ferreti et al. 1995, Kageyama \& Gandara 2000). O caráter de pioneirismo e agressividade competitiva dessa espécie, somados à sua tolerância higromórfica e boa interação biótica, garante o sucesso regenerativo em ambientes fortemente edáficos e também com influência antrópica (Kageyama \& Gandara 2000). Isso a caracteriza como espécie típica dos estádios pioneiro e secundário inicial (Ferreti et al. 1995) e, possivelmente, como uma bioindicadora do caráter edáfico dos ambientes naturais ou antropizados. É importante salientar que os frutos de muitas espécies da família são atrativos da fauna, principalmente da avifauna (Krügel et al. 1998, Guimarães 2003), demonstrando a importância da sua utilização em programas de recomposição de vegetação.

No que se refere às espécies exóticas invasoras de Anacardiaceae, Mangifera indica foi recentemente categorizada como invasora das florestas Ombrófila, Estacional e Estacional Semidecidual, das Savanas e Savanas Estépicas do Brasil (Zenni \& Ziller 2011). Schinus terebinthifolius, espécie nativa do Brasil, Argentina, Paraguai e Uruguai, foi introduzida em áreas subtropicais em todo mundo (Ewel et al. 1982). Na Flórida e Havaí, esta espécie foi introduzida como planta ornamental e tornou-se uma das espécies invasoras mais amplamente distribuídas e nocivas desses Estados. Registros históricos indicam que $S$. terebinthifolius foi introduzida, separadamente, na costa leste e oeste da Flórida (Schmitz et al. 1997). Análises genéticas recentes demonstram que as duas introduções supracitadas são provenientes de diferentes populações e que houve hibridizações extensivas (Williams et al. 2005). Estes híbridos são superiores aos seus progenitores em relação à germinação da semente, sobrevivência da plântula e crescimento (Geiger et al. 2011), além disso, a quantidade atual de variação genética encontrada nas populações de $S$. terebinthifolius da Flórida é equivalente às encontradas nas populações nativas da América do Sul (Williams et al. 2005, Geiger et al. 2011). Schinus molle, espécie nativa da América do Sul, foi introduzida como planta ornamental e tornou-se bem estabilizada na América Central, México e nas regiões temperadas quentes e subtropicais do mundo (Barkley 1957b). Na África do Sul, é classificada como a principal planta daninha ( $\mathrm{Nel} 2004)$, sendo que, recentemente, começou a invadir as savanas semiáridas naturais da província do Cabo (Iponga et al. 2009). 
Historicamente, os membros de Anacardiaceae foram, por um período relativamente longo, incluídos em uma família mais abrangente, a das Terebinthaceae, que englobava também os atuais membros de Burseraceae e outros gêneros pouco conhecidos na época. A. P. De Candolle (1825), no Prodomus, por exemplo, incluía na "ordo" Terebinthaceae as Connaraceae, Burseraceae, Picramnia (Simaroubaceae) e alguns gêneros atualmente classificados como Rutaceae. Baillon (1878) restringiu um pouco a delimitação de Terebinthaceae, mas ainda incluía nesta família, táxons da atual família Icacinaceae. Marchand (1869), no trabalho Histoire de l'ancien Groupe des Térébinthacées, faz um histórico das Terebinthaceae, apresentando todas as classificações dos diversos autores até aquela data. O reconhecimento de Anacardiaceae, como uma família com circunscrição semelhante à atual, está presente nos trabalhos de Bentham \& Hooker (1862), Marchand (1869) e Engler (1876, 1883 e 1896), porém, ainda nessa época, Jadin (1894) considerava Anacardiaceae e Burseraceae como uma única família, as Terebinthaceae.

No que concerne à autoria da família, Jussieu (1789) descreveu as Terebinthaceae, porém, Brown (1818) propôs a separação desta grande família em três menores: Cassuviae ou Anacardeae, Amyrideae e Connaraceae; e posteriormente, Anacardiaceae foi reconhecida como família por Lindley (1830). A literatura é controversa sobre a autoria da família. Algumas obras reconhecem Anacardiaceae Lindley como nome aceito porque Brown teria usado o nome Anacardeae somente como um sinônimo, enquanto outras obras, inclusive Pell et al. (2011), aceitam Anacardiaceae R. Br. nom. cons. De acordo com Hoogland \& Reveal (2005), R. Brown validou Anacardiaceae por meio de uma diagnose em inglês e referência à obra de Jussieu (1789), o qual já havia realizado uma diagnose da família em latim; dessa forma Anacardiaceae Lindley é um isônimo, pois refere-se ao mesmo táxon e material-tipo, embora seja um nome publicado posteriormente.

$\mathrm{Na}$ classificação intrafamiliar, Bentham \& Hooker (1862) distinguiram duas tribos: Anacardieae e Spondieae. Engler publicou posteriormente duas grandes monografias, sendo que na primeira (1883) ele dividiu a família em 4 tribos. A segunda monografia (1896) foi mais abrangente, incluindo dados sobre a morfologia, anatomia, biologia floral, distribuição geográfica e afinidades com outras famílias. Neste trabalho, além de considerar as tribos anteriores, Mangiferae (=Anacardieae), Spondieae (=Spondiadeae), Rhoideae (=Rhoeae) e Semecarpeae, Engler (1896) acrescenta mais uma tribo, Dobineeae (=Dobinaeae). Scholz (1964) manteve na última edição do Syllabus der Pflanzenfamilien essa mesma divisão em tribos, com a diferença que para a tribo Mangiferae utilizou o nome Anacardieae. Embora as obras de Engler $(1883,1896)$ retivessem a revisão mais minuciosa e ampla de Anacardiaceae, o 
conjunto de caracteres utilizado para cada tribo era diferente, gerando, consequentemente, sobreposição entre os limites tribais (Pell 2004).

Takhtajan (1987) reconheceu as subfamílias Anacardioideae, Spondioideae (incluindo Rhoeae e Semecarpeae), Julianoideae (anteriormente Julianaceae), Pistacioideae (anteriormente incluída em Rhoeae) e Dobineoideae, sendo esta última subfamília elevada à família Podoaceae. Wannan \& Quinn $(1990,1991)$ distinguiram dois principais grupos na família, $A$ e $B$, baseados principalmente na anatomia do fruto (endocarpos tipo-Anacardium e tipo-Spondias), na morfologia floral e nos flavonóides, sendo que o grupo A era constituído essencialmente pelas tribos Anacardieae, Dobinaeae, Rhoeae e Semecarpeae, propostas por Engler (1896), com exceção de Androtium, Buchanania, Campnosperma e Pentaspadon que juntamente com Spondiadeae formavam o grupo B.

Para entendimento das relações filogenéticas da família Anacardiaceae, Terrazas (1994 apud Mitchell et al. 2006) utilizou uma análise combinada de dados moleculares das sequências do gene rbcL juntamente com dados morfológicos, corroborando a monofilia da família e propondo informalmente o reconhecimento de duas subfamílias, Spondioideae e Anacardioideae, mas sem definir as respectivas circunscrições.

Mais recentemente, para reconstruir a filogenia de Anacardiaceae, Pell (2004) utilizou sequências de três genes de cloroplasto, obtendo dois clados principais que foram resolvidos em sua maioria por meio de sequências de $t r n L-F$ e organizados como as subfamílias citadas por Terrazas (1994 apud Mitchell et al. 2006). Essas duas subfamílias são mais relacionadas com as propostas por Bentham \& Hooker (1862) do que com as de Takhtajan (1997). Na proposta de Pell (2004), a subfamília Anacardioideae compreende quatro das tribos de Engler (1896): Anacardieae, Dobinaeae, Rhoeae, Semecarpeae e muitos gêneros não conhecidos por ele. A subfamília Spondioideae inclui Spondiadeae sensu Engler expandida. A subfamília Anacardioideae é caracterizada por apresentar principalmente folhas simples ou compostas, estames em número variável, 1 carpelo ou 3 conatos, 1 lóculo, 1-3 estiletes conatos ou livres e endocarpo Anacardium-tipo; enquanto Spondioideae apresenta geralmente folhas compostas, estames obdiplostêmones, 4-5 carpelos, lóculos e estiletes, e endocarpo tipo-Spondias. No conceito de Wannan (2006), Anacardioideae parece ser definida pela sinapomorfia carpelo fértil antessépalo e a outra subfamília não possui sinapomorfia definida, porém, pode ser reconhecida pelo pericarpo não estratificado, característica compartilhada com Burseraceae (simplesiomorfia). Apesar dos estudos morfológicos e moleculares das últimas décadas contribuírem consideravelmente para a classificação intrafamiliar de 
Anacardiaceae, mais esforços são necessários, pois as relações filogenéticas entre os táxons da subfamília Spondioideae não estão totalmente resolvidas e o seu monofiletismo ainda não foi corroborado (Pell 2011).

A circunscrição e monofilia de Anacardiaceae, e sua relação como grupoirmão de Burseraceae estão bem estabelecidas (Gadek et al. 1996, Savolainen et al. 2000b, Pell 2004). A presença de canais resiníferos no xilema primário, os canais secretores intercelulares verticais no floema primário e secundário e a eficiência na síntese de biflavonóides são as sinapomorfias que sustentam Burseraceae como grupo-irmão de Anacardiaceae (Gadek 1996, Pell 2011). Embora existam efetivamente muitas semelhanças entre as duas famílias, elas se distinguem principalmente pelos dois óvulos epítropos por lóculo em Burseraceae e um óvulo apótropo em Anacardiaceae (Wannan 2006). Adicionalmente, é possível elencar algumas características que não são exclusivas de cada família, mas que frequentemente auxiliam na separação de ambas, tais como a ausência de compostos químicos em Burseraceae que podem ser encontrados em Anacardiaceae; a presença de estípulas e pseudoestípulas, além de pulvínulo terminal em Burseraceae e ausentes em Anacardiaceae (Pell 2004).

A maioria das classificações tem posicionado a família Anacardiaceae na ordem Sapindales ou Rutales (Bentham \& Hooker 1862, Cronquist 1981, Dahlgren 1980, Takhtajan 1987), e atualmente está bem corroborada sua inclusão como membro da ordem Sapindales (Chase et al. 1993, Gadek et al. 1996, Bremer et al. 1999, Savolainen et al. 2000a, 2000b; APG 2003, 2009).

Estudos sistemáticos em Pistacia, Protorhus, Rhus e Toxicodendron têm sido produzidos utilizando como base as filogenias moleculares (Miller 2001, Yi 2007, 2008, Pell et al. 2008, Nie et al. 2009). Esses estudos elucidam o posicionamento e o relacionamento entre os táxons em vários níveis hierárquicos como, por exemplo, complexos, níveis intragenéricos e interespecíficos; auxiliam na resolução dos problemas de delimitação; e testam a monofilia do táxon. Além disso, trazem implicações biogeográficas essenciais para o entendimento do padrão de distribuição atual e história evolutiva dos táxons. Dados moleculares do DNA (microssatélites e RAPDs) e do cloroplasto (espaçadores intergênicos) também já foram empregados nos estudos de genética de população, filogeografia e conservação do germoplasma em Myracrodruon urundeuva (Reis \& Grattapaglia 2004, Caetano et al. 2005, 2008).

Entre os estudos taxonômicos na família, é importante citar os de Barkley, que incluem uma chave para as tribos e gêneros de toda a família (1957a) e revisões de alguns gêneros americanos, como Rhus (1937), Schinus (1957b), Lithrea (1962a), Loxopterygium (1962b) e Astronium (1968). Outras revisões mais recentes foram 
providas sobre os gêneros Anacardium (Mitchell \& Mori 1987), Myracrodruon (Santin \& Leitão-Filho 1991), Thyrsodium (Mitchell \& Daly 1993). Novos táxons de Spondias, Tapirira, Cyrtocarpa e Anacardium têm sido descritos na América do Sul, inclusive no Brasil (Mitchell \& Mori 1987; Mitchell \& Daly 1991, 1998; Wendt \& Mitchell 1995) e problemas taxonômicos foram resolvidos em algumas espécies de Tapirira (Mitchell 1993) e Cyrtocarpa (Mitchell \& Daly 1991).

Estudos morfológicos e evolutivos recentes, realizados na família Anacardiaceae, incluem a anatomia caulinar para auxiliar na sistemática do grupo (Terrazas \& Wendt 1995; Terrazas 1995, 1999), o pericarpo (Wannan \& Quinn 1990), a biologia floral e evolução das Anacardiaceae (Wannan \& Quinn 1991) e mais recentemente, Bachelier \& Endress (2009) realizaram um estudo comparativo da anatomia e morfologia floral de Anacardiaceae e Burseraceae com foco na estrutura do gineceu e evolução.

Dentre os estudos florísticos tratando de Anacardiaceae neotropicais, podem ser citados o levantamento dessa família para as Floras da Argentina (Cabrera 1938, Muñoz 2000), do Panamá (Blackwell \& Dodson 1968), do Paraguai (Muñoz 1990), das Guianas (Mitchell 1997) e do Valle de Lerma na Argentina (Varela \& Novara 2007), além do Guia llustrado das Árvores do Peru (Pennington et al. 2004a). Para o Brasil, o levantamento das Anacardiaceae já foi realizado na Flora do Rio Grande do Sul (Fleig 1981), Reserva do Parque Estadual Fontes do Ipiranga em São Paulo (Pirani 1981), Serra do Cipó (Pirani 1987), Santa Catarina (Fleig 1989), Reserva Ducke em Manaus (Mitchell 1999), Ilha do Cardoso em São Paulo (Pirani 2002), Grão-Mogol em Minas Gerais (Pirani 2003), Flora do Semiárido da Bahia (Alves 2004), Acre (Mitchell 2008), Flora de Mirandiba no Pernambuco (Argemiro et al. 2009), checklist da Flora de Alagoas (Lemos et al. 2010) e mais recentemente foi elaborada a lista das espécies de Anacardiaceae no Catálogo de Plantas e Fungos do Brasil (Silva-Luz \& Pirani 2010).

Atualmente, com o declínio da biodiversidade devido à interferência humana, as floras ganham maior importância, pois auxiliam muito no conhecimento da vegetação. Portanto, é imprescindível que se conheça bem a flora do Brasil, uma vez que o país possui uma grande diversidade de formas vivas, e como país em desenvolvimento, ainda tem muito que realizar para caracterizar as suas espécies nativas (Giulietti et al. 2005, Mittermeier et al. 2005, Pirani 2006).

O conhecimento e entendimento da biodiversidade de uma área dependem de identificações acuradas, caso contrário, as conclusões podem ser errôneas. Nesse sentido, os trabalhos de floras são importantes para garantir rápida e eficiente identificação de espécies, além de auxiliar estudos ambientais de uma determinada área e subsidiar respostas para questões sobre evolução (Funk 2006). 
Do século XVII até o final do século XIX, botânicos como Saint-Hilaire, Gardner, Pohl, Sellow e Martius visitaram o país para estudar as paisagens e a flora do Brasil (Giuletti et al. 2005, Forzza et al. 2010). Porém, o Estado de São Paulo foi pouco visitado por esses naturalistas, quando comparado com o Rio de Janeiro e Minas Gerais (Joly 1950a). Em todo o Estado, apenas dois tratamentos taxonômicos locais de Anacardiaceae foram realizados (Pirani 1981, 2002). No entanto, esses trabalhos são restritos a pequenas áreas, não havendo tratamento geral da família no Estado.

Com os avanços na área da taxonomia vegetal no Brasil, a Sociedade Botânica do Brasil, em 1991, recomendou à comunidade científica um esforço no sentido de melhorar o conhecimento da biodiversidade, e dessa maneira foi criado 0 projeto "Flora Fanerogâmica do Estado de São Paulo" (Wanderley et al. 2001). O projeto tem sido subsidiado pela FAPESP desde 1994 e conta com equipes de taxonomistas das três universidades estaduais e dos institutos de pesquisa estaduais. Até agora, foram publicados tratamentos detalhados de 130 famílias, abrangendo 118 gêneros e 2767 espécies.

Nesse contexto, essa dissertação de mestrado tem os seguintes objetivos:

- elaborar o tratamento da flora da família Anacardiaceae no Estado de São Paulo, provendo descrições morfológicas, chaves de identificação, ilustrações e dados sobre distribuição geográfica, habitat, variabilidade intraespecífica e fenologia das espécies, segundo o modelo da série "Flora Fanerogâmica do Estado de São Paulo"

- avaliar o grau de conservação das espécies e do risco de extinção, pois algumas espécies de Anacardiaceae encontram-se dentro de alguma categoria de extinção de acordo com a resolução SMA 08 de 31-01-2008;

- contribuir para o conhecimento da família Anacardiaceae no Brasil, uma vez que várias das espécies estudadas apresentam ampla distribuição no país e ainda existem lacunas de dados detalhados sobre aspectos da sua morfologia, variabilidade e circunscrição taxonômica. 


\section{Materiais e métodos}

\section{1 Área de estudo}

O Estado de São Paulo está localizado entre as latitudes $19^{\circ} 47^{\prime}$ e $2^{\circ}{ }^{\circ} 19^{\prime} S$ e longitudes $53^{\circ} 06^{\prime}$ e $44^{\circ} 10^{\prime} \mathrm{W}$ e tem uma área de $248256 \mathrm{~km}^{2}$. Apresenta clima tropical superúmido na baixada litorânea e escarpas da Serra do Mar; tropical de altitude na região do Planalto Atlântico; tropical quente e úmido na região noroeste do Estado; subtropical úmido na região sul; e subtropical com inverno seco e verão quente/úmido no Planalto Ocidental. O relevo compreende um gradiente altimétrico que vai de $0 \mathrm{~m}$ no litoral a 2797m na Serra da Mantiqueira (Pedra Mina). O Estado pode ser compartimentado em cinco províncias geomorfológicas: Costeira, Planalto Atlântico, Depressão Periférica, Cuestas Basálticas e Planalto Ocidental (Nalon et al. 2008).

A vegetação do Estado de São Paulo é muito diversificada por situar-se no limite entre as regiões tropical e subtropical, exibindo por isso uma flora transicional com elementos tropicais e elementos característicos de regiões subtropicais. Apresenta também os limites de contato entre tipos de vegetação muito distintos, como a Floresta Ombrófila Densa (Mata Atlântica sensu stricto) da Serra do Mar, a Savana (cerrados) do oeste do Estado e a Floresta Estacional Semidecidual do interior. Destacam-se ainda, áreas menores abertas com outros tipos de vegetação, especialmente na região costeira, incluindo restinga, vegetação de dunas arenosas e manguezais, além das florestas nebulares acima dos 1200m (Floresta Ombrófila Densa Alto-Montana), a floresta mista com Araucaria e Podocarpus (Floresta Ombrófila Mista) e dos campos de altitude que ocorrem até um máximo de $2500 \mathrm{~m}$ (Wanderley et al. 2001, Nalon et al. 2008).

Até o século XIX, o Estado ainda apresentava sua vegetação primitiva (Wanderley et al. 2001). A partir do século passado, $80 \%$ da vegetação foi substituída, restando apenas fragmentos isolados de alguns ecossistemas como o domínio do Cerrado e da Mata Atlântica (Brito et al. 1999).

No Estado de São Paulo localizam-se os principais remanescentes de Mata Atlântica (Scudeller et al. 2001). Existem 236 áreas naturais protegidas no Estado, divididas em 21 categorias de manejo de âmbito federal, estadual e particular (unidades de proteção integral, unidades de uso sustentável e outras áreas especialmente protegidas). Apesar desse número de unidades de conservação, ainda existem ambientes sem status de proteção. Instituições internacionais indicam que os países deveriam proteger um mínimo de 10\% do território de cada província biogeográfica, e o Brasil, inclusive o Estado de São Paulo, está longe da proteção ideal (Xavier et al. 2008). Tanto o domínio do Cerrado quanto o da Mata Atlântica 
encontram-se entre os 25 "hotspots" de biodiversidade, ou seja, áreas com grande concentração de espécies endêmicas e ameaçadas de extinção (Myers et al. 2000), porém a maior parte das unidades de conservação corresponde às áreas do domínio de Mata Atlântica (Brito et al. 1999).

\subsection{Análise dos materiais}

O estudo foi desenvolvido no Laboratório de Sistemática Vegetal do Departamento de Botânica, Instituto de Biociências da USP. Foram analisados 959 espécimes herborizados provenientes do Estado de São Paulo (tabela 1). Materiais adicionais de outros Estados e/ou informações bibliográficas foram utilizadas para complementar as descrições morfológicas dos táxons tratados, sobretudo nos casos de ausência de dados oriundos da área de estudo. O levantamento das espécies de Anacardiaceae do Estado de São Paulo foi elaborado por meio da consulta aos herbários listados na tabela 1 e da literatura, principalmente estudos florísticos e inventários, além de teses e dissertações disponíveis nos bancos de teses nos sítios da Universidade de São Paulo, Universidade Estadual de Campinas e Universidade Estadual Paulista (Botucatu e Rio Claro).

Os dados morfológicos foram obtidos a partir da análise de material vivo e preservado em álcool, obtidos durante expedições de coleta (tabela 2), de exsicatas dos herbários citados na tabela 1 e fotos dos herbários BM (Museu de História Natural, London - England), LIL (Fundação Miguel Lillo, Tucumã - Argentina), P (Museu Nacional de História Natural, Paris - França) e S (Museu de História Natural, Estocolmo - Suécia). Em relação às expedições de coleta, foram visitados os municípios de Alambari, Areias, Campos do Jordão (Parque Estadual de Campos do Jordão), Capão Bonito (Floresta Nacional de Capão bonito), Franco da Rocha (Parque Estadual do Juqueri), Itaberá, Itapetininga, Itapeva (Estação Ecológica de Itapeva), Itatinga, Ribeirão Grande, São Paulo (Núcleo Curucutu do Parque Estadual da Serra do Mar), Tatuí e Ubatuba (Núcleo Picinguaba do Parque Estadual da Serra do Mar). Materiais coletados durante viagens a campo foram herborizados conforme técnicas convencionais, depositados no herbário SPF e duplicatas foram distribuídas a outros herbários. Foram utilizados nas análises morfológicas apenas estruturas completamente desenvolvidas, com exceção de Myracrodruon urundeuva, a qual apresentava semente em desenvolvimento. A observação detalhada do material foi feita sob estereomicroscópio SZ Olympus, com uso do retículo milimétrico do microscópio para estruturas diminutas, e para estruturas acima de $1 \mathrm{~cm}$ foi utilizado paquímetro. Fotografias das estruturas reprodutivas foram realizadas em estereomicroscópio Leica M125 equipado com câmera digital Leica DFC 425. As flores 
foram re-hidratadas com gotas de glicerina por cerca de 60 segundos em forno de microondas. A terminologia morfológica segue Radford (1986), Ellis et al. (2009), Weberling (1989) e a literatura de Anacardiaceae para emprego de certas especificidades da família e dos gêneros estudados.

Tabela 1: Número de espécimes estudados de Anacardiaceae do Estado de São Paulo, atualizados quanto à determinação e fotografados em cada herbário brasileiro visitado.

\begin{tabular}{lc}
\multicolumn{1}{c}{ Herbário } & Número de espécimes \\
\hline BHCB - Universidade Federal de Minas Gerais - MG & 2 \\
BOTU - Universidade Estadual Paulista - Botucatu, SP & 61 \\
ESA - Universidade de São Paulo - Piracicaba, SP & 100 \\
IAC - Instituto Agronômico de Campinas - Campinas, SP & 40 \\
HRCB - Universidade Estadual Paulista - Rio Claro, SP & 45 \\
MBM - Museu Botânico Municipal - Curitiba, PR & 9 \\
PMSP - Prefeitura do Município de São Paulo - São Paulo, SP & 6 \\
R - Museu Nacional - Rio de Janeiro, RJ & 9 \\
RB - Jardim Botânico do Rio de Janeiro, Rio de Janeiro, RJ & 13 \\
SP - Instituto de Botânica - São Paulo, SP & 215 \\
SPF - Universidade de São Paulo - São Paulo, SP & 213 \\
SPSF - Instituto Florestal - São Paulo, SP & 128 \\
UEC - Universidade Estadual de São Paulo, Campinas, SP & 118 \\
\hline
\end{tabular}

A análise taxonômica foi feita com base na caracterização, diferenciação e comparação das espécies com a literatura sobre Anacardiaceae. Todos os dados foram constantemente confrontados com a literatura específica, notadamente as revisões taxonômicas realizadas por Barkley (1957a,b, 1962, 1968), Mitchell \& Mori (1987), Mitchell \& Daly (1991), Mitchell (1993). Além da consulta às obras específicas da família, foram acessados sítios especializados, tais como W3Tropicos, o Angiosperm Phylogeny Website e o International Plant Name Index.

As abreviações para títulos de livros seguiram Stafleu \& Cowan (1976), para periódicos Bridson \& Smith (1991) e para nomes de autores Brummitt \& Powell (1992) e IPNI.

Os dados sobre o estado de conservação das espécies são fornecidos com base nas categorias propostas pela IUCN (2001), porém modificadas e adequadas para aplicação no Estado de São Paulo (Souza et al. 2007). A classificação da vegetação do Estado de São Paulo seguiu o sistema proposto por Veloso et al. (1991), para as demais localidades utilizou-se uma nomenclatura genérica. Os dados de distribuição das espécies utilizados na confecção dos mapas são oriundos dos herbários visitados (tabela 1). Para a produção dos mapas de Lithrea brasiliensis e Schinus engleri foram utilizados, além dos dados de herbários mencionados acima, as 
localidades citadas na revisão de Lithrea (Barkley 1962) e na revisão de Schinus (Barkley 1957b). Para a elaboração do mapa de distribuição de Schinus engleri não foram utilizados dados da sua distribuição total, pois esse táxon apresenta problemas de delimitação, sendo assim, optou-se por inserir as localidades provenientes de materiais que foram analisados (Minas Gerais, São Paulo e Paraná). As coordenadas para elaboração dos mapas de distribuição geográfica foram obtidas tomando como base o município em que foi coletado o material. Os mapas foram produzidos com o programa Diva-Gis 5.2 (Hijmans 2005) e a camada de altimetria é proveniente do sítio DIVA-GIS.

\section{Resultados e discussão}

\subsection{Flora Fanerogâmica do Estado de São Paulo}

\section{ANACARDIACEAE}

Árvores, arbustos, raro subarbustos ou lianas, inermes ou raramente armados, aromáticas, canais resiníferos bem desenvolvidos principalmente na casca. Folhas alternas, raro opostas ou verticiladas, geralmente imparipinadas, às vezes trifoliadas ou simples, sem estípulas; folíolos alternos, opostos ou subopostos, margem inteira, serrada, dentada, crenada ou crenado-serrada, venação pinada. Inflorescências axilares ou terminais, panículas, racemos, pseudorracemos, tirsóides ou espigas; pedicelos articulados ou não, brácteas e bractéolas decíduas ou persistentes. Flores unissexuais e/ou bissexuais (plantas dióicas, monóicas, andromonóicas, polígamas ou hermafroditas), diclamídeas, actinomorfas, hipóginas, geralmente 5-meras, estaminódios ou pistilódios bem desenvolvidos; sépalas livres ou conatas na base, decíduas ou persistentes, às vezes acrescentes no fruto; pétalas livres, prefloração valvar ou imbricada; estames 5-10, em 1 ou 2 verticilos e neste caso obdiplostêmones, livres ou conatos na base; disco nectarífero anular, geralmente intraestaminal, às vezes ausente; ovário súpero, geralmente sincárpico, (1-)3-5carpelar, 1(-2-5)-locular; óvulo 1 por lóculo, anátropo, apical, basal ou lateral; estiletes $1-5$, terminais ou laterais. Fruto geralmente drupa, carnoso ou seco, alado ou não, às vezes com cálice cartáceo acrescente ou com hipocarpo carnoso; sementes 1-4(-12), endosperma escasso ou ausente.

A família possui aproximadamente 81 gêneros e 800 espécies, presentes em ambientes secos a úmidos, principalmente em terras baixas nas regiões tropicais e subtropicais em todo o mundo, estendendo-se até as regiões temperadas (Pell 2011). Nas Américas existem aproximadamente 32 gêneros nativos, sendo que $77 \%$ das espécies são endêmicas do continente americano e poucos desses gêneros possuem 
representantes em outros continentes (Terrazas 1999). No Brasil, estão catalogados 14 gêneros e 57 espécies, sendo 14 delas restritas ao país (Silva-Luz \& Pirani 2010). No Estado de São Paulo, há 12 espécies nativas distribuídas em sete gêneros: Anacardium L., Astronium Jacq, Lithrea Miers ex Hook. \& Arn., Myracrodruon Allemão, Schinus L., Spondias L. e Tapirira Aubl.

São cultivadas no Estado de São Paulo as espécies Harpephyllum caffrum Bernh. ex C. Krauss, Mangifera indica L.(mangueira), Schinus molle L. (aroeirasalsa), Spondias dulcis Parkinson (cajá-manga), S. purpurea L. (seriguela), S. venulosa (Engl.) Engl. (cajá-grande), S. tuberosa Arruda (umbuzeiro), Toxicodendron radicans L., T. striatum (Ruiz \& Pav.) Kuntze e T. succedaneum (L.) Kuntze (as três últimas conhecidas como charão e sumac).

Barkley, F.A. 1957a. Generic key to the Sumac family (Anacardiaceae). Lilloa 20(4): 255-265.

Cabrera, A.L. 1938. Revision de las Anacardiáceas Austroamericanas. Revista Mus. La Plata, Secc. Bot. 6: 1-64.

Engler, H.G.A. 1876. Anacardiaceae. In Martius, C.F.P. \& Eichler, A.G. (eds.) FI. bras. Fleischer, Leipzig, vol.12, pars 2, p. 367-418.

Engler, H.G.A. 1886. Anacardiaceae. In A.DC. \& C.DC. (eds.) Monographie Phanerogamarum Masson, Paris, vol. 4, p. 171-500.

Fleig, M. 1981. A família Anacardiaceae no Rio Grande do Sul, Brasil. Iheringia, Bot. 28: 141-155.

Fleig, M. 1989. Anacardiáceas. In R. Reitz (ed.) Flora llustrada catarinense. Herbário Barbosa Rodrigues, Itajaí, 64 p.

Muñoz, J.D. 1990. Anacardiaceae. In Flora del Paraguay. Conservatoire et Jardin botaniques de la Ville de Géneve; Missouri Botanical Garden, Saint Louis, p. 7-84.

Muñoz, J.D. 2000. 153. Anacardiaceae. In A.T. Hunkizer (ed.) Flora Fanerogamica Argentina. Proflora (Conicet), Cordoba, fasc. 65, p.1-28.

Pell, S.K., Mitchell, J.D., Miller, A.J. \& Lobova, T.A. 2011. Anacardiaceae. In K. Kubitzki (Ed.) The families and genera of vascular plants. X. Flowering plants. Eudicots. Sapindales, Curcubitales, Myrtales. Springer, Berlin, p. 750.

Pirani, J.R. 1987. Flora da Serra do Cipó, Minas Gerais: Anacardiaceae. Bol. Bot. Univ. São Paulo 9: 199-209.

Pirani, J.R. 2002. Anacardiaceae. In Barros et al. (eds) Flora Fanerogâmica da Ilha do Cardoso. Instituto de Botânica, São Paulo, vol. 9, p. 45-50. 
Pirani, J.R. 2003. Flora de Grão-Mogol, Minas Gerais: Anacardiaceae. Bol. Bot. Univ. São Paulo 21(1): 61-65.

Silva-Luz, C.L. \& Pirani, J.R. 2010. Anacardiaceae. In R.C. Forzza et al. (org.) Catálogo de plantas e fungos do Brasil. Rio de Janeiro: Jardim Botânico do Rio de Janeiro, v. 1, p. 599-602.

\section{Chave para os gêneros}

1. Folhas simples; ramos inermes; nervura marginal ausente; disco intraestaminal ausente; pedicelo do fruto dilatado e carnoso (hipocarpo)

1. Anacardium

1'. Folhas geralmente compostas, se simples, então ramos com ápice espinescente ou folhas com nervura marginal conspícua; disco intraestaminal presente; hipocarpo ausente.

2. Folhas com nervura marginal conspícua ou com nervura intramarginal.

3. Folhas compostas com raque foliar não alada; nervura marginal inconspícua; nervura intramarginal presente; flores bissexuais

6. Spondias

3'. Folhas compostas com raque alada ou simples; nervura marginal conspícua; nervura intramarginal ausente; flores unissexuais

3. Lithrea

2'. Folhas com nervura marginal inconspícua e sem nervura intramarginal.

4. Árvores caducifólias; estames 5; cálice ampliado (acrescente) no fruto.

5. Flores masculinas sem pistilódio; fruto baga; folíolos com ápice longoacuminado, faces adaxial e abaxial glabras ou na nervura primária com tricomas geralmente curtos, curvados no ápice, esparsos

2. Astronium

5'. Flores masculinas com pistilódio; fruto drupa; folíolos com ápice agudo, acuminado, obtuso ou mucronado, faces adaxial e abaxial na nervura primária e margem com tricomas longos, levemente sinuosos ou sinuosos, densos

4. Myracrodruon

4'. Árvores ou arbustos perenifólios; estames 8-10; cálice não ampliado no fruto.

6. Folhas compostas com raque e pecíolo não alados; venação broquidródoma; flores com pedicelo não articulado

7. Tapirira

6'. Folhas compostas com raque e pecíolo alados ou folhas simples; venação semicraspedródoma, craspedródoma ou cladódroma; flores com pedicelo articulado

5. Schinus 


\section{Anacardium $L$.}

Árvores, arbustos ou subarbustos, perenifólios; ramos inermes, eretos ou semipendentes; sistema caulinar subterrâneo bem desenvolvido nas espécies geoxílicas campestres. Folhas simples, adensadas em direção ao ápice, cartáceas ou coriáceas, pecioladas, margem inteira, ondulada, base assimétrica, venação broquidródoma ou cladódroma, face adaxial com nervuras planas ou impressas, às vezes proeminentes, face abaxial com nervuras geralmente proeminentes, domácias nas axilas das nervuras secundárias da face abaxial. Inflorescência axilar ou terminal, tirsóide corimbiforme, laxa ou congesta, pedunculada; brácteas e bractéolas persistentes ou decíduas. Flores pediceladas, pedicelo não articulado, 5-meras, bissexuais ou masculinas (plantas andromonóicas); sépalas conatas apenas na base; pétalas alvas ou verde-claras com linhas vermelhas ou rosa na antese e vermelhoescuro após a fertilização, imbricadas, reflexas na antese, tubo campanulado ou cilíndrico; estames 6-12, desiguais, 1-4 maiores que os demais, filetes unidos na base, anteras presentes ou ausentes, tubo estaminal com altura desigual; ovário 1-carpelar, 1-locular; óvulo basal; estilete 1, longo, central ou lateral; estigma 1, geralmente puntiforme; pistilódio nas flores masculinas; disco intraestaminal ausente. Fruto drupa reniforme, lateralmente compressa ou obovóide no ápice de um hipocarpo carnoso (o pedicelo espessado); pericarpo coriáceo, resinífero; semente 1, reniforme, testa livre do endocarpo, embrião curvo.

Gênero composto por 11 espécies, naturalmente distribuídas de Honduras até o Brasil no Paraná e leste do Paraguai; na Venezuela, Colômbia e Equador ocorrem apenas a oeste dos Andes. O gênero possui dois centros de diversidade localizados na Amazônia Central e no Planalto Central do Brasil. Algumas espécies são árvores de grande porte, encontradas nas florestas tropicais úmidas, matas de galeria e florestas inundáveis; as demais espécies, geralmente arvoretas ou arbustos, são encontradas em áreas abertas de cerrado, caatinga e restingas (Mitchell \& Mori 1987). As espécies campestres têm marcante hábito geoxílico: desenvolvem um grande sistema caulinar subterrâneo, ficando expostos na superfície do solo apenas os ápices dos ramos e folhas (López-Naranjo 1975, 1977).

Mitchell, J.D. \& Mori, S.A. 1987. The cashew and its relatives (Anacardium: Anacardiaceae). Mem. New York Bot. Gard. 42:1-76.

López-Naranjo, H.J. 1975. Estrutura morfológica de Anacardium humile St.

Hil. Anacardiaceae. Dissertação de mestrado, Universidade de São Paulo, São Paulo. 80 p. 
López-Naranjo, H. 1977. Hábito de crescimento y estructura de lãs yemas de

Anacardium humile A. St.-Hil. Anacardiaceae. Revista Forestal Venezolana 27: 159-173.

Chave para as espécies de Anacardium

1. Plantas campestres ou de cerrado, com hábito geoxílico (tronco subterrâneo ca. $1 \mathrm{~m})$; folhas rígido-cartáceas ou coriáceas; pétalas 4,5-8mm compr. 1. A. humile

1'. Plantas de restinga, arbóreas até $6 \mathrm{~m}$; folhas cartáceas; pétalas 9,4-12,5mm compr.

2. A. occidentale

1.1. Anacardium humile A. St.-Hil., Ann. Sc. nat. (Paris) 23: 272. 1831.

Prancha 1, fig. C-F.

Anacardium pumilum A. St.-Hil. ex Engl. in Mart. \& Eichler., FI. bras. 12(2): 411, t. 88. 1876.

Nome popular: caju-do-campo, cajuí, caju-rasteiro, cajuzinho, cajuzinho-docampo, caju-do-cerrado.

Plantas geoxílicas, tronco subterrâneo ca. $1 \mathrm{~m}$, ramos ascendentes aéreos ca. $40 \mathrm{~cm}$, geralmente glabros. Folhas rígido-cartáceas ou coriáceas; pecíolo não alado, 0,5$1,5 \mathrm{~cm}$, glabro ou com tricomas curtos, adpressos, retos, esparsos; lâmina 12,5$24,5 \times 4,9-7,8 \mathrm{~cm}$, geralmente oblanceolada, às vezes obovada, ápice arredondado ou obtuso, às vezes retuso, base geralmente côncava, cuneada, convexa ou decurrente, às vezes auriculada, face adaxial glabra, face abaxial glabra ou com tricomas longos, adpressos, retos, esparsos, principalmente na nervura primária. Tirsóides terminais, amarelo-esverdeados, $12-28,5 \mathrm{~cm}$; pedúnculo 2,5-9,5cm, tricomas curtos, adpressos, retos, esparsos, aumentando em direção ao ápice; brácteas proximais 6,7-17,5×2,7$3 \mathrm{~cm}$, oblanceoladas, glabras, semelhante às folhas; brácteas distais 2,4-4,5x0,4$1,2 \mathrm{~cm}$, lanceoladas, oblanceoladas, obovadas ou oblongas, glabras ou na nervura primária com tricomas curtos, adpressos, retos, esparsos; brácteas da base das cimeiras $0,7-1,2 \times 0,2-0,5 \mathrm{~cm}$, oblongas ou ovais, faces adaxial e abaxial com tricomas curtos ou longos, às vezes espessados na base, densos, às vezes indumento levemente seríceo na face abaxial; bractéolas 1,5-2,5x0,6-1,3mm, ovais ou lanceoladas, face adaxial glabra, face abaxial com tricomas curtos, adpressos, retos, densos, indumento seríceo. Flores: pedicelo 2,3-3,6mm, seríceo como nas bractéolas; sépalas verde-claras, 2,8-4x0,8-1,8mm, ovais ou lanceoladas, ápice acuminado ou agudo, face adaxial glabra, face abaxial com indumento seríceo; pétalas 4,5-8x1-2mm, lineares ou lanceoladas, ápice acuminado ou obtuso, face adaxial glabra ou com 
tricomas curtos, eretos, retos, esparsos, face abaxial com indumento seríceo; estames nas flores masculinas $6-8$, o maior $2,4-7,8 \mathrm{~mm}$, os menores $1,3-4 \mathrm{~mm}$, anteras normais; estames nas flores bissexuais $5-9$, o maior $6-8,9 \mathrm{~mm}$, os menores $1,2-1,7 \mathrm{~mm}$; ovário ovóide ou irregularmente globoso, glabro; estilete ca. 7,2 $\mathrm{mm}$, lateral ou levemente central. Drupas verdes, cinéreas ou marrons, $12-23 \times 9-17 \mathrm{~mm}$, glabras; hipocarpo amarelo ou vermelho, piriforme ou obcônico, 1-3x1-2cm.

Anacardium humile ocorre nos campos e cerrados, na Bolívia (região de Santa Cruz), sul e leste do Paraguai, e no Brasil do sudeste de Rondônia e norte de Goiás até o Paraná. B2, B6, C5, C6, D3, D4, D5, D6, D7, E5, E6, E7, E8, F4: nas diversas fitofisionomias de campo e cerrado, e em áreas antropizadas, geralmente associadas a solo arenoso. Coletada com flores de julho a outubro e em dezembro, com frutos de agosto a novembro. O fruto e o hipocarpo são apreciados e consumidos regionalmente.

Material selecionado: Águas de Santa Bárbara, IX.2008, N. Guerin et al. 160 (SPSF). Agudos, VIII.2001, M.E.S. Paschoal 2471 (BOTU). Araraquara, X.1993, Y.T. Rocha s.n. (ESA 33296). Itapetininga, VII.1962, M.S. Labouriau 111 (RB, SP). Itararé, IX.1989, C.A.M. Scaramuzza 531 (ESA). Itirapina, IX.1984, O. Cesar 214 (HRCB, SPF). Itu, II.1961, A.S. Grotta 259 (SPF). Mogi-Guaçu, VIII.1980, W. Mantovani 843 (SP, SPF). Pedregulho, X.2003, D. Sasaki \& A.F. Sartori 776 (SPF). Rancharia, IX.1974, G. Hatschbach 34812 (SPF). Santa Rita do Passa Quatro, IX.1995, M.A. Batalha 677 (SPF). São José dos Campos, VIII.1949, W. Hoehne s.n. (CTES, F, G, IPA, K, MBM, SP, SPF 12453). São Paulo, VIII.1949, W. Hoehne s.n. (CEN, CEPEC, CESJ, FUEL, HRCB, HUEFS, MBM, MO, NY, R, RB, SPF 12536, UB, US, W). Suzanópolis, VIII.1995, M.R. Pereira-Noronha 1633 (ESA, HRCB, SP, SPF).

Espécie muito característica pelo hábito geoxílico e por apresentar folhas simples agregadas em direção ao ápice, que quando maceradas exalam odor de resina semelhante ao de manga verde. A interpretação do hábito geoxílico de Anacardium humile é controvertida, sendo que a espécie já foi caracterizada como árvore, arbusto, subarbusto e até mesmo como planta rasteira. A forma biológica de $\mathbf{A}$. humile confunde-se com arbustiva ou subarbustiva devido à ramificação dos eixos ao nível do solo, porém, quando desenterrados, mostram-se porções ascendentes de um grande corpo caulinar subterrâneo e não plantas individuais isoladas, conforme demonstrou o estudo anatômico de López-Naranjo (1975, 1977). 


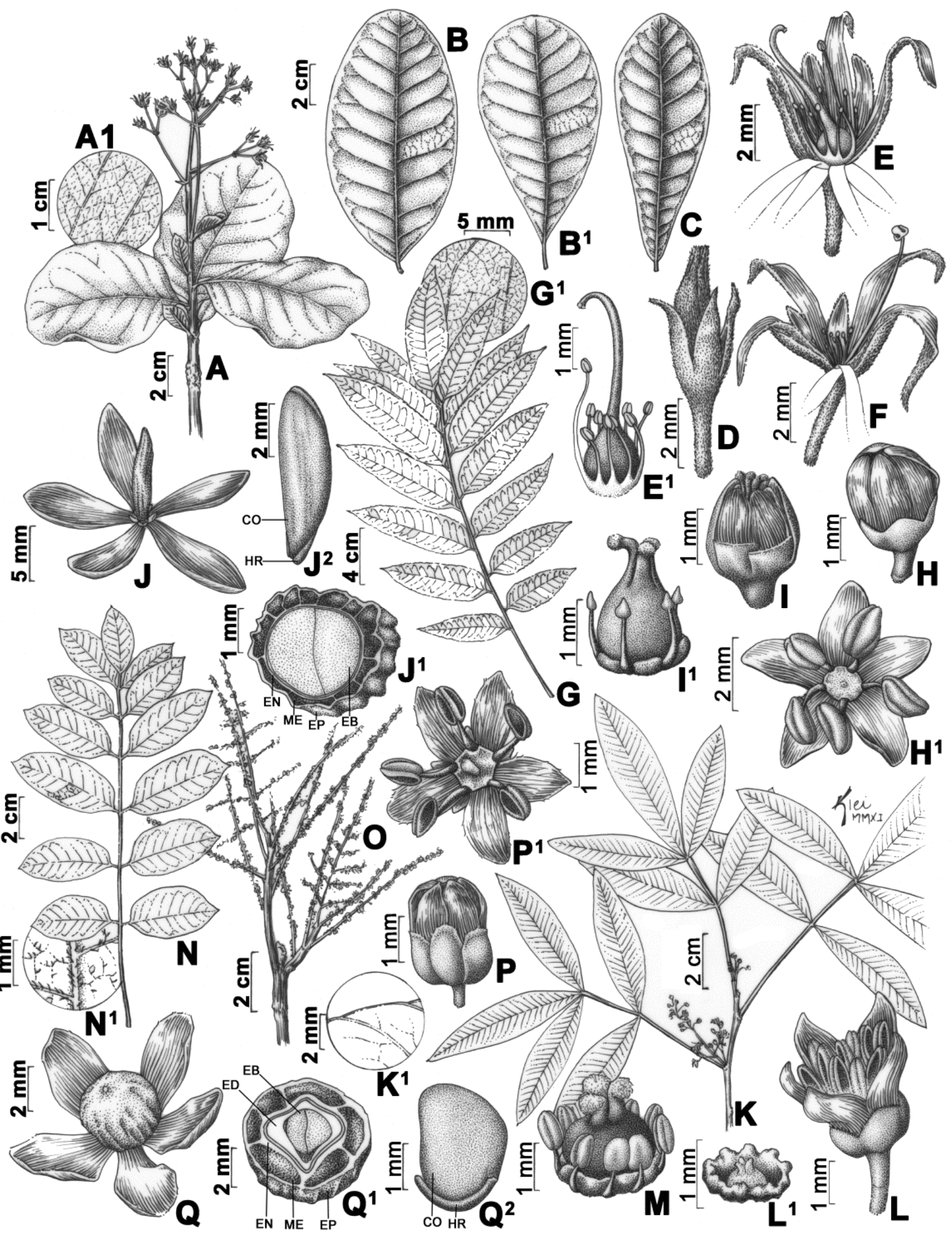


1.2. Anacardium occidentale L., Sp. pl. 1: 383. 1753.

Prancha 1, fig. A-B ${ }^{1}$ e Prancha 2, fig. A-B

Anacardium curatellaefolium A. St.-Hil., Ann. Sc. nat. (Paris) 23: 272. 1831

Anacardium microcarpum Ducke, Arch. Jar. Bot. Rio de Janeiro 3: 202. 1922.

Anacardium rondonianum Machado, Arch. Jar. Bot. Rio de Janeiro 9: 87. 1949.

Anacardium amilcarianum Machado, Arch. Jar. Bot. Rio de Janeiro 9: 88. 1949.

Anacardium kuhlmannianum Machado, Arch. Jar. Bot. Rio de Janeiro 9: 89. 1949.

Anacardium othonianum Rizzini, Anais Acad. Brasil. Ci. 41(2): 243. 1969.

Nome popular: caju, cajueiro, caju-da-praia.

Árvores, 2-6m, ramos lenticelados, glabros ou com tricomas esparsos, no ápice com tricomas curtos, espessados na base, adpressos ou oblíquos, retos, densos. Folhas cartáceas; pecíolo não alado, 0,4-1,4cm, tricomas como no ápice dos ramos; lâmina 5,3-22x3,7-11,5cm, obovada, oblonga ou largamente oblonga, ápice arredondado, obtuso, retuso ou emarginado, base auriculada, levemente auriculada, cuneada ou decurrente, face adaxial glabra ou na nervura primária com tricomas curtos, adpressos, retos, face abaxial na base com tricomas densos e na nervura primária com tricomas esparsos. Tirsóides terminais, amarelo-esverdeados, 9-17,5cm; pedúnculo 2,5-8cm, tricomas curtos ou longos, adpressos ou oblíquos, retos ou levemente sinuosos, esparsos, aumentando em direção ao ápice; brácteas proximais 2,5-11x1,8-6,1 cm, oblongas ou ovais, tricomas como nas folhas; brácteas distais 1,4$2,1 \times 0,4-1,1 \mathrm{~cm}$, oblanceoladas ou obovadas, tricomas longos, adpressos, sinuosos, esparsos na face adaxial, densos na face abaxial; brácteas da base das cimeiras 4,5$8 \times 1,8-4,8 \mathrm{~mm}$, ovais ou deltadas, às vezes lineares, indumento seríceo; bractéolas 57,7x2,7-3,3mm, deltadas, indumento seríceo. Flores: pedicelo 3,2-6,5mm, seríceo como ..nas ..bractéolas;. sépalas ..verde-claras, ..3,3-5x1,7-3,4mm,. ovais, .às .vezes

Prancha 1. A-B ${ }^{1}$. Anacardium occidentale, A. ramo florífero; $A^{1}$. detalhe das nervuras da face abaxial; $\mathrm{B}-\mathrm{B}^{1}$. variação foliar. C-F. Anacardium humile, C. folha; D. botão floral; E. flor bissexual, com duas sépalas e duas pétalas rebatidas evidenciando o gineceu e o androceu; $E^{1}$. gineceu e androceu, sem perianto; F. flor masculina, com uma sépala e uma pétala rebatidas evidenciando o androceu. G- $J^{2}$. Astronium graveolens, $\mathrm{G}$. folha; $\mathrm{H}$. botão floral masculino; $\mathrm{H}^{1}$. flor masculina na antese em vista frontal; I. botão floral feminino, com duas sépalas seccionadas; ${ }^{1}$. gineceu, estaminódios e disco intraestaminal, sem perianto; J. fruto com cálice ampliado em vista frontal; $\mathrm{J}^{1}$. corte transversal do fruto mostrando 0 epicarpo (EP), mesocarpo (ME) com 12 lacunas, endocarpo (EN) fino e membranáceo e o embrião (EB); $\mathrm{J}^{2}$. embrião em vista lateral (CO. cotilédone, HR. eixo hipocótilo-radicular). K-M. Lithrea molleoides, K. ramo florífero; $K^{1}$. detalhe da nervura marginal do folíolo; $L$. flor masculina na antese; $L^{1}$. pistilódio e disco intraestaminal; M. flor feminina na antese, sem perianto. $N-Q^{2}$. Myracrodruon urundeuva, N. folha; $N^{1}$. detalhe do indumento da face abaxial do folíolo. O. ramo florífero; $P$. botão floral masculino; $P^{1}$. flor masculina na antese em vista frontal; $Q$. fruto com cálice ampliado em vista frontal; $Q^{1}$. corte transversal do fruto mostrando o epicarpo (EP), mesocarpo (ME) com 6 lacunas, endocarpo (EN) coriáceo e anguloso, e a semente em desenvolvimento com endosperma (ED) envolvendo o embrião (EB); $Q^{2}$. embrião em vista lateral (CO. cotilédone, HR. eixo hipocótilo-radicular). (A. Loebmann SPF 201238; B. Jorge SPF 165799; B ${ }^{1}$. Pirani 4516; C-E'. Hoehne 12536; F. Naranjo 102; G. Gandolfi 365; $\mathrm{H}^{1} \mathrm{H}^{1}$. Ivanauskas SPF 201247; I-I'. Chaddad 250; J-J². Gandolfi 365; K-L. Sasaki 680; M. Tamashiro 708; N-N'. Cipolla SP 14542; O-P. Jaccond 69; Q-Q2. Assis 259). Ilustrações: Klei Rodrigo Sousa. 
largamente ovais, ápice acuminado ou agudo, face adaxial com tricomas esparsos, face abaxial com tricomas densos, indumento seríceo; pétalas 9,4-12,5×1,6-2,4mm, lineares ou lanceoladas, ápice acuminado, face adaxial com tricomas curtos ou longos, adpressos ou eretos, sinuosos, esparsos, face abaxial com indumento como nas sépalas; estames nas flores masculinas 6-11, o maior 5,4-8mm, os menores $1,8-3 \mathrm{~mm}$, anteras normais; estames nas flores bissexuais 6-10, o maior $5-9,8 \mathrm{~mm}$, os menores 22,5mm; ovário globoso, glabro; estilete ca. $7 \mathrm{~mm}$, central. Drupas cinéreas ou marrons, 12-35x9-2mm, glabras; hipocarpo amarelo, laranja ou vermelho, piriforme, 5-20x2$8 \mathrm{~cm}$.

A. occidentale possui distribuição natural incerta devido ao longo histórico de associação com a espécie humana. Mitchell \& Mori (1987) acreditam que a distribuição natural estende-se do norte da América do Sul (savanas da Colômbia, Venezuela e Guinas) até São Paulo, no Brasil, ocorrendo nos cerrados do planalto central, nas savanas da Amazônia, na caatinga e nas restingas. E7, E8, G6: nas restingas do litoral paulista. Foram considerados espécimes nativos de São Paulo somente as populações das restingas, pois os exemplares provenientes de outras regiões do Estado são claramente colhidos de plantas cultivadas. Coletada com flores em fevereiro e de setembro a dezembro. Anacardium occidetale é cultivada nas regiões tropicais do Novo e Velho Mundo. Espécie com destaque econômico, apresenta o fruto (castanha-de-caju) e o fruto acessório (hipocarpo) comestíveis e muito apreciados mundialmente. Do cajueiro ainda é possível extrair, da parede do fruto, o líquido "CNS", utilizado pela indústria na produção de plásticos, tintas, resinas e vernizes.

Material selecionado: Bertioga, XI.2003, S.O. Jorge et al. S.n. (SPF 165799). Cananéia, XI. 1974, J.R. Mattos et al. 16265 (SP). Cubatão, VII.1946, B. Pickel s.n. (SPSF 2580).

Material adicional examinado: ALAGOAS, Maceió, I.1993, J.R. Pirani et al. 2670 (HUEFS, NY, SPF). GOIÁS, Cavalcanti, VIII.2005, M.L. Fonseca et al. 5882 (IBGE, SPF). GOIÁS, Padre Bernardo, XI.1987, G.P. Silva 520 (SPF). RIO DE JANEIRO, Arraial do Cabo, V.1993, J.R. Pirani et al. 2892 (G, NY, SP, SPF).

Anacardium occidentale exibe ampla variabilidade na forma e textura das folhas. Porém no Estado de São Paulo é prontamente distinta por apresentar porte arborescente, enquanto A. humile, espécie similar em relação às folhas e a inflorescência, possui hábito geoxílico. 


\section{Astronium Jacq.}

Árvores, caducifólias; ramos inermes. Folhas compostas, imparipinadas, membranáceas ou cartáceas, pecioladas; raque não alada; folíolos subopostos, opostos ou alternos, margem crenada, serrada ou crenado-serrada, base assimétrica ou simétrica, venação cladódroma, nervura primária proeminente ou plana na face adaxial e proeminente na face abaxial, nervuras secundárias planas na face adaxial e proeminentes na face abaxial. Inflorescência axilar ou terminal, tirsóide, pedunculada; brácteas e bractéolas caducas ou decíduas. Flores pediceladas, pedicelo articulado, 5-meras, às vezes 6-meras, unissexuais em plantas dióicas; sépalas livres, maiores que as pétalas nas flores femininas; pétalas imbricadas; estames 5(-6), iguais, entre os lobos do disco, anteras complanadas ou ovóides; estaminódios nas flores femininas 5; ovário 3-carpelar, 1-locular; óvulo subapical; estiletes 3, curtos; estigmas 3, capitados ou globosos; pistilódio ausente nas flores masculinas; disco intraestaminal 5-lobado. Fruto baga elipsóide circundada pelo cálice persistente e ampliado (pseudosâmara); epicarpo fino; mesocarpo lacunoso, fino, resinífero; endocarpo membranáceo; semente 1, embrião reto ou levemente curvo; corola e estaminódios persistentes ou não.

Gênero neotropical, com cerca de oito espécies, ocorrendo desde o México até o Paraguai. No Brasil, o gênero compreende sete espécies que são bem representadas em todas as regiões, com exceção da região sul.

Barkley, F.A. 1968. Anacardiaceae: Rhoideae: Astronium. Phytologia 16(2): 107-152.

Bernardi, A.L. 1959. El gênero Astronium Jacq. Bol. Soc. Venez. Ci. Nat. 20(44): 348-359.

Mattick, Fr. 1934. Die gattung Astronium. Notizbl. Bot. Gart. Berlin-Dahlen 11(110): 991-1012.

Santin, D.A. 1989. Revisão taxonômica do gênero Astronium Jacq. e revalidação do gênero Myracrodruon Fr. Allemão. Dissertação de mestrado, Universidade Estadual de Campinas, Campinas. 178 p.

2.1. Astronium graveolens Jacq., Enum. syst. pl. 33. 1760.

Prancha 1, fig. G-J² e Prancha 2, fig. C-E.

Nome popular: guaritá, aroeira.

Árvores, 8-18m, ramos jovens lenticelados, glabros ou com tricomas curtos, eretos, retos ou curvados no ápice, esparsos. Folhas $20,5-43 \mathrm{~cm}$, geralmente cartáceas; pecíolo não alado, 2-8,2cm, tricomas como nos ramos jovens; folíolos 11-17, alternos, 
opostos ou subopostos, peciolulados; peciólulos laterais 1-6mm, o do folíolo terminal 4-21mm; lâmina dos folíolos laterais e terminal 5,6-11,x1,6-3,3cm, geralmente oblonga, oval ou oval-lanceolada, às vezes elíptica ou obovada, ápice longoacuminado, margem crenada, levemente serrada ou crenado-serrada, ondulada, base assimétrica, cuneada, côncava ou convexa, faces adaxial e abaxial glabras ou na nervura primária com tricomas geralmente curtos, eretos, curvados no ápice, esparsos. Tirsóides axilares ou terminais, creme-vináceos, masculinos 11,5-15,5cm, femininos ca. 11,6cm; pedúnculo 2-2,6cm, tricomas como nos ramos jovens; brácteas 0,9-1,5x0,5-1 mm, ovais, deltadas ou oblongas, côncavas, escariosas, tricomas curtos, oblíquos, retos, densos na face externa; bractéolas vináceas, 0,5-1×0,3-0,6mm, ovais, lanceoladas ou deltadas, escariosas, glabras. Flores: pedicelo verde-vináceo, 0,7$1 \mathrm{~mm}$, articulado a $0,1-0,3 \mathrm{~mm}$ do cálice, tricomas longos, eretos, sinuosos, esparsos; sépalas verdes, nas flores masculinas $1,2 \times 0,9 \mathrm{~mm}$, nas femininas ca. 1,7-1,9×1,4$1,5 \mathrm{~mm}$, ovais, largamente ovais ou orbiculares, côncavas, ápice arredondado ou obtuso, ambas faces glabras; pétalas creme ou creme-vináceas, nas flores masculinas

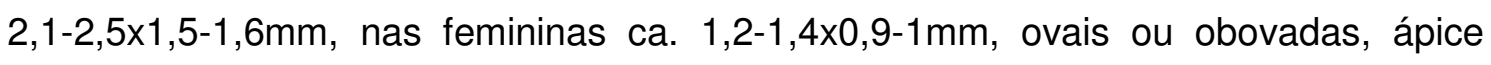
arredondado, ambas faces glabras; nas flores masculinas estames 2,8mm; nas flores femininas estaminódios 0,5-0,9mm e ovário ovóide, glabro. Bagas castanhas, 9,6x2,6mm diâm., glabras; sépalas espatuladas, ampliadas até 9,7-10×3,6mm, glabras.

Astronium graveolens é amplamente distribuída na América, ocorrendo no México, América Central até o Brasil, Bolívia e Paraguai, nas florestas Ombrófilas Densas e Estacionais, cerrados e matas ciliares. É a única espécie do gênero que ocorre na região sul do Brasil. C6, C7, D1, D5, D6, D7, F4: nas florestas Estacionais Semideciduais, matas ciliares, cerrados e áreas antropizadas. Coletada com flores de agosto a setembro e em dezembro, com frutos em setembro. Possui madeira de boa qualidade utilizada em acabamentos internos e construções externas, além de ser recomendada para uso em paisagismo.

Material selecionado: Águas da Prata, VII.1990, D.V. Toledo-Filho 26032 (UEC). Brotas, IX.1991, S. Zickel 30270 (UEC). Cajuru, VIII.1986, L.C. Bernacci 270 (UEC). Itararé, VIII.1946, M. Kuhlmann s.n. (SPF 83487, SP). Mogi-Guaçu, VIII.1966, H.F. Leitão-Filho 478 (IAC). Piracicaba, VIII.2003, J. Chaddad-Junior 250 (ESA). Teodoro Sampaio, VIII.1986, J.B. Baitello 203 (SPSF).

Astronium graveolens apresenta características vegetativas e reprodutivas muito semelhantes a A. fraxinifolium Schott ex Spreng. A separação desses táxons baseia-se principalmente no predomínio de folíolos pilosos em A. fraxinifolium, e glabros em A. graveolens, porém são observados indivíduos com graus intermediários de pilosidade. Esses táxons já foram considerados conspecíficos face 
à sobreposição dos caracteres forma e pilosidade dos folíolos (Blackwell \& Dodson 1968), mas podem ser tratados como distintos considerando-se os habitats e aspecto da casca (Santin 1989). A. graveolens é uma espécie de florestas Ombrófila Densa e Estacional Semidecidual, apresenta casca fina que ao desprender-se não deixa depressões acentuadas no tronco, enquanto A. fraxinifolium ocorre geralmente no cerrado e possui casca suberosa que ao desprender-se deixa depressões no tronco. No entanto, um estudo mais detalhado das populações de diferentes formações vegetacionais é necessário para avaliar se as características do tronco são consistentes e relevantes na separação das duas espécies ou tratam-se apenas de variação fenotípica em resposta a diferentes ambientes. Com base nos caracteres diagnósticos tradicionalmente utilizados para identificar essas espécies, os exemplares do Estado de São Paulo são mais adequadamente tratados como A. graveolens por apresentarem folíolos geralmente oblongos e glabros ou na nervura primária com tricomas esparsos pouco conspícuos em ambas as faces.

Bibliografia adicional

Blackwell Jr., W.H. \& Dodson, C.H. 1968. Flora of Panama. Anacardiaceae. Ann. Missouri Bot. Gard. 54(3): 351-379.

\section{Lithrea Miers ex Hook. \& Arn.}

Árvores ou arbustos, perenifólios; ramos inermes, delgados, resiníferos. Folhas simples ou compostas, imparipinadas, coriáceas ou cartáceas, sésseis ou pecioladas; raque alada às vezes apenas estreitamente; folíolos opostos, margem inteira ou crenada, base simétrica ou assimétrica, venação craspedródoma ou semicraspedródoma, nervura primária proeminente e secundárias proeminentes ou planas nas faces adaxial e abaxial, nervura marginal cartilaginosa, conspícua. Inflorescência axilar ou agrupada nas axilas dos ramos superiores, panícula, pedunculada; brácteas e bractéolas geralmente decíduas. Flores pediceladas, pedicelo articulado, 5-meras, unissexuais em plantas dióicas; sépalas conatas apenas na base; pétalas valvares; estames 10 , obdiplostêmones, iguais ou subiguais, entre os lobos do disco, anteras complanadas; estaminódios nas flores femininas 10, dotados de anteras, mas desprovidos de pólen; ovário 3-carpelar, 1-locular; óvulo basal; estilete 1; estigmas 3, capitados; pistilódio nas flores masculinas com óvulo reduzido; disco intraestaminal 10-lobado. Fruto drupa, globosa; epicarpo fino, lustroso, separando-se quando maduro do mesocarpo negro e resinífero; endocarpo coriáceo; semente 1, complanada; cálice e estaminódios persistentes; resquícios de estigmas. 
Gênero sul-americano, com três espécies, ocorrendo na região central do Chile, sul e sudeste do Brasil, no Paraguai, Uruguai e Argentina. O principal caráter diagnóstico na identificação das espécies é a presença de folhas simples ou compostas, porém, às vezes, os dois tipos de folhas podem ocorrer em um mesmo espécime. O gênero foi citado primeiramente por Miers (1826), mas sem diagnose ou descrição em latim; posteriormente, Hooker \& Arnott (1833) fizeram uma descrição mais adequada, validando o gênero Lithrea. A etimologia de Lithrea deriva de "litre", nome chileno designado para a espécie-tipo. No entanto, o gênero apresenta outra variante ortográfica, Lithraea, grafia utilizada em grandes obras de referência, tais como Engler (1876, 1886, 1892).

As resinas de Lithrea podem causar dermatite de contato em pessoas susctíveis.

Barkley, F.A. 1962a. Anacardiaceae: Rhoideae: Lithraea. Phytologia 8(7): 329-365.

\section{Chave para as espécies de Lithrea}

1. Folhas simples, sésseis ou curto-pecioladas (pecíolo 0,1-0,5cm compr.) 1. L. brasiliensis

1'. Folhas compostas, pecíolo 1,4-4,3cm compr.

2. L. molleoides

3.1. Lithrea brasiliensis Marchand, Rév. Anacardiac. 183. 1869.

Prancha 2, fig. L.

Nome popular: aroeira-brava.

Árvores ou arbustos, 2-10m, ramos jovens lenticelados, glabros ou com tricomas curtos, eretos, retos, esparsos. Folhas simples, cartáceas ou coriáceas, sésseis ou curto-pecioladas; pecíolo inconspícuo, não alado, $0,1-0,5 \mathrm{~cm}$, tricomas como nos ramos jovens; lâmina 3-9,2×1-2,4cm, elíptica, obovada, oblanceolada, oblonga ou oval, ápice mucronado, emarginado, obtuso ou truncado, margem inteira ou levemente crenada, ondulada, levemente revoluta, base simétrica ou levemente assimétrica, decurrente, face adaxial glabra, brilhante, face abaxial glabra ou na margem e nervura primária com tricomas longos, eretos, sinuosos, esparsos. Panículas alvoesverdeadas, masculinas 2,2-5,2cm, femininas 2-4,1cm; pedúnculo 0,5-0,8cm, tricomas como nos ramos jovens brácteas $1-1,3 \times 0,7-0,9 \mathrm{~mm}$, deltadas ou lanceoladas, tricomas longos, adpressos ou oblíquos, sinuosos, esparsos; bractéolas 0,7-1,3×0,3$0,4 \mathrm{~mm}$, deltadas, na margem com tricomas curtos ou longos, eretos ou oblíquos, retos, esparsos. Flores: pedicelo 1-2,1 $\mathrm{mm}$, articulado a 0,3-0,9mm do cálice, tricomas como no pedúnculo, glabro acima da articulação; sépalas verdes, 1,1-1,4×0,9-1,2mm, 
côncavas, deltadas, triangulares ou suborbiculares, ápice arredondado ou obtuso, ambas faces glabras, margem com tricomas curtos, eretos ou oblíquos, retos, esparsos; pétalas alvas, 1,6-2,9×0,9-1,6mm, ovais, ápice agudo ou obtuso, ambas faces glabras; estames nas flores masculinas 1,5-2,1 $\mathrm{mm}$; estaminódios nas flores femininas $0,5-0,7 \mathrm{~mm}$; ovário globoso, glabro. Drupas verde-claras ou verdeacinzentadas, 5-7mm diâm., glabras.

Lihtrea brasiliensis distribui-se no Uruguai, Argentina, e no sul e sudeste do Brasil. Ocorre em florestas Ombrófila Densa, Mista e Estacional, capões de mata e restingas. O único exemplar de Lithrea brasiliensis proveniente do Estado de São Paulo é de uma coleta de Gaudichaud de 1833, porém, tal exemplar não traz referência precisa do local de coleta, impossibilitando a inferência da quadrícula. Buscas de novos registros da espécie no Estado mostraram-se infrutíferas tanto a campo como nos herbários.

Material selecionado: São Paulo, 1833, C. Gaudichaud 925 (BM isolectótipo, P Lectótipo).

Material adicional examinado: MINAS GERAIS, A. St.-Hil. 1762 (BM); MINAS GERAIS, A. St.-Hil. 1772 (BM). PARANÁ, Colombo, sem data, P.R. Andrade s.n. (MBM 29912). PARANÁ, Curitiba, X.1979, G. Hatschbach 80, (MBM, SPF). PARANÁ, Curitiba, X.1964, Y. Saite \& M.L. Pereira 439 (MBM). PARANÁ, Curitiba, XI.1974, L.T. Dombrowski 5492 (MBM). RIO DE JANEIRO, Cabo Frio, III.2007, C. Farney 4657 (RB, SPF). SANTA CATARINA, Mafra, XI.2007, S. Dreveck 22 (FURB, SPF). SANTA CATARINA, Urubici, XI.2001, G. Hatschbach et al. 72492 (MBM, SPF). RIO GRANDE DO SUL, Bom Jesus, XI.2006, G.O. Romão 1828 (ESA, SPF). RIO GRANDE DO SUL, Vacaria, IV.1983, J.R. Pirani \& O. Yano 649 (SP, SPF).

Na revisão do gênero, Barkley (1962a) cita coletas de L. brasiliensis em São Paulo e Minas Gerais, sendo que as coletas do Estado de São Paulo correspondem a Gaudichaud 925, espécime designado como lectótipo, e Betzler s.n., coletado em 1947 e identificado posteriormente por aquele especialista como Lithrea molleoides. Os materiais provenientes de Minas Gerais são coletas de Saint-Hilaire (1762 e 1772) e tratam-se de espécimes de L. brasiliensis. No entanto, o estudo das coleções de diversos herbários mostra que não há registros posteriores de Lithrea brasiliensis nos Estados supracitados. É possível que as populações da espécie em Minas Gerais e São Paulo fossem pequenas e escassas e acabaram sendo extintas localmente com a destruição de habitats. Porém há registros recentes da espécie nas restingas de Cabo Frio, no Rio de Janeiro e, portanto a distribuição atual da espécie parece ser disjunta, com populações restritas no Rio de Janeiro e as demais no sul do Brasil, Uruguai e Argentina. As populações do Rio de Janeiro apresentam folhas obovadas 
com ápice truncado ou emarginado; enquanto os espécimes do sul do Brasil, Argentina e Uruguai possuem folhas geralmente oblongas com ápice mucronado (figura 5). A espécie deve ser categorizada como presumivelmente extinta (EX) no Estado de São Paulo, de acordo com os critérios utilizados por Souza et al. (2007).

Ilustrações em Fleig $(1981,4)$

Bibliografia adicional

Souza, V.C., Mamede, M.C.H., Cordeiro, I., Prado, J., Barros, F., Wanderley, M.G.L., Kageyama, P.Y., Ceccantini, G. \& Rando, J.G. 2007. Critérios uilizados na elaboração da Lista oficial de espécies da flora ameaçadas de extinção no Estado de São Paulo. In M.C.H. Mamede, V.C. Souza, J. Prado, F. Barros, M.G.L. Wanderley \& J.G. Rando (Org.). Livro vermelho das espécies vegetais ameaçadas do Estado de São Paulo. 1 ed. São Paulo: Instituto de Botânica, p. 15-20.

3.2. Lithrea molleoides (Vell.) Engl. in Mart. \& Eichler, Fl. bras. 12(2): 394, tab. 83. 1876.

Prancha 1, fig. K-M e Prancha 2, fig. F.

Schinus molleoides Vell., Fl. flumin. 10: pl. 134. 1825.

Nome popular: aroeira-branca, aroeira-brava, aroeirinha.

Árvores, 3-8m, ramos jovens lenticelados, glabros ou com tricomas curtos, eretos, às vezes oblíquos, geralmente retos, esparsos. Folhas 7,1-14cm, compostas, imparipinadas, raramente simples, cartáceas, pecioladas; pecíolo estreitamente alado, $(0,4-) 1,4-4,3 \mathrm{~cm}$, tricomas como nos ramos jovens; folíolos 3-5, opostos, sésseis; lâmina 3,1-6,9 $\times 0,9-2,2 \mathrm{~cm}$, no folíolo terminal 4,1-8x1,3-2,9cm, obovada, oval, oblonga ou elíptica, ápice mucronado, margem inteira, ondulada, base assimétrica, cuneada ou decurrente, às vezes côncava ou convexa, faces adaxial e abaxial glabras. Panículas alvo-esverdeadas, masculinas $2,6-10 \mathrm{~cm}$, femininas $4,5-7,5 \mathrm{~cm}$; pedúnculo $0,5-1,6 \mathrm{~cm}$, tricomas geralmente curtos, eretos, retos, esparsos; brácteas 1-1,6×0,9-1,2mm, deltadas, tricomas longos, adpressos, eretos ou oblíquos, retos ou sinuosos, esparsos; bractéolas 0,6-1,7×0,4-0,8mm, deltadas, tricomas curtos, oblíquos, retos, geralmente na margem. Flores: pedicelo 1,1-2mm, articulado a $0,4-0,7 \mathrm{~mm}$ do cálice, tricomas como no pedúnculo, glabro acima da articulação; sépalas verdes, 0,9-1,7×0,6-1,5mm, largamente triangulares ou ovais, ápice agudo ou obtuso, ambas faces glabras, margem com tricomas curtos, oblíquos, retos, esparsos; pétalas alvas, 1,5-2,3×0,9$1,3 \mathrm{~mm}$, ovais, às vezes largamente elípticas, ápice geralmente agudo, glabras; estames nas flores masculinas 1,1-1,7mm; estaminódios nas flores femininas 0,6- 
0,9mm; ovário globoso, às vezes ovóide ou obovóide, glabro. Drupas verdes ou verde-acinzentadas, (4-)5-6mm diâm., glabras.

Lithrea molleoides apresenta distribuição no centro-oeste e sudeste do Brasil até o Uruguai, centro-norte da Argentina, no Paraguai e centro-sul da Bolívia. É comum em capoeiras, borda de matas, mata de encosta e em formações secundárias, em terrenos secos ou brejosos. B3, B4, B6, C4, C6, D3, D4, D5, D6, D7, D8, E4, E5, E6, E7, E8, E9, F4, F5: na floresta Estacional, matas ciliares, cerrados e áreas antropizadas; coletada com flores de março a maio e de julho a novembro, com frutos o ano todo.

Material selecionado: Anhembi, I.1995, K.D. Barreto 3462 (ESA). Assis, IX.1992, G. Durigan s.n. (UEC 77913). Bauru, IX.1996, M.H.O. Pinheiro 118 (ESA, UEC). Campos do Jordão, XI.1994, M.J. Robim \& J.P.M. Carvalho 8775 (SPSF). Cunha, VIII.1948, J. Kiehl 5199 (ESA, IAC). Embu, XII. 2005, N.M. Ivanauskas et al. 6111 (ESA, SPSF). Iperó, VIII.1994, J.B. Baitello 695 (HRCB, SP, SPF, SPSF, UEC). Itapeva, XI.1994, V.C. Souza et al. 7101 (ESA, HRCB, SP, SPF, UEC). Itapira, I.1994, K.D. Barreto 1765 (ESA). Itararé, X.1993, C.M. Sakuragui 488 (ESA). Paulo de Faria, X.1994, A.L. Maestro \& A.M. Silveira 77 (ESA, HRCB, SP, SPF, UEC). Pedregulho, VIII.2003, D. Sasaki \& A.B. Junqueira 680 (SPF, SPSF, RB). Santo Antônio da Alegria, XI.1994, A.M.G.A. Tozzi \& A. Sciamarelli 58 (HRCB, SP, SPF, UEC). São Carlos, VII.1993, P.H.P. Ruffino 133 (HRCB). Sud Mennucci, VIII.1995, M.R. PereiraNoronha et al. 1328 (SP, SPF, UEC). Taquarituba, IX.1994, J.Y. Tamashiro et al. 708 (ESA, HRCB, SP, SPF, SPSF, UEC). Taubaté, I.1942, A. Lofgren et al. 1827 (SP).

Lithrea molleoides é prontamente distinta das demais espécies do gênero por apresentar folhas compostas, raramente simples. Barkley (1962a) baseado na morfologia dos folíolos reconheceu duas variedades, a típica e L. molleoides var. Iorentziana Hieron. ex Lillo, enquanto Cabrera (1938) não considerou categorias infraespecíficas e colocou também em sinonímia Lithrea ternifolia (Gillies) F.A. Barkley.

\section{Myracrodruon Allemão}

Árvores ou arvoretas, caducifólias; ramos inermes. Folhas compostas, imparipinadas, membranáceas ou cartáceas, pecioladas; raque não alada; folíolos subopostos ou opostos, margem inteira ou serrada, base assimétrica ou simétrica, venação cladódroma ou semicraspedródoma, nervura primária proeminente em ambas as faces atenuando-se no ápice, nervuras secundárias planas na face adaxial e levemente proeminentes na face abaxial. Inflorescência axilar ou terminal, tirsóide, pedunculada; brácteas e bractéolas caducas. Flores curtamente pediceladas, pedicelo 
articulado, 5-meras, unissexuais em plantas dióicas; sépalas inconspicuamente conatas apenas na base, côncavas, maiores que as pétalas nas flores femininas; pétalas imbricadas; estames 5 , iguais, entre os lobos do disco, anteras complanadas, longitudinalmente auriculadas na base; estaminódios nas flores femininas 5 , dotados de anteras, mas desprovidos de pólen; ovário 3-carpelar, 1-locular; óvulo sub-basal; estiletes 3, curtos; estigmas 3, capitados ou globosos; pistilódio nas flores masculinas, com óvulo abortivo; disco intraestaminal 5-lobado. Fruto drupa, ovóide ou globosa, circundado pelo cálice persistente e ampliado (pseudosâmara); epicarpo membranáceo; mesocarpo membranáceo, lacunoso, resinífero; endocarpo coriáceo, anguloso; semente 1, eixo hipocótilo-radicular curvo, acumbente, endosperma ausente na semente madura; corola e estaminódios persistentes ou não; resquícios do disco intraestaminal e estigma.

Gênero sul-americano, com apenas duas espécies, ocorrentes no Brasil, Bolívia, Paraguai e norte da Argentina. O histórico taxonômico de Myracrodruon é marcado por instabilidade, sendo que seu status já foi de gênero, na ocasião de sua descrição (Allemão 1862), passou a seção de Astronium (Engler 1876), a subgênero de Astronium (Barkley 1968) e mais recentemente foi restabelecido como gênero (Santin 1991) baseado no tipo de placentação e fruto, caracteres tradicionalmente utilizados na delimitação genérica em Anacardiaceae. Nas filogenias moleculares recentes, Myracrodruon e Astronium emergem como clados-irmãos, podendo, portanto ser reconhecidos tanto em nível genérico como infragenérico (Pell com. pess.).

Santin, D.A. \& Leitão-Filho, H.D. 1991. Restabelecimento e revisão taxonômica do gênero Myracrodruon Freire Allemão (Anacardiaceae). Revista Brasil. Bot. 14: 133-145.

Carmello-Guerreiro, S.M. 1999. Aspectos morfológicos e anatômicos da semente de aroeira (Myracrodruon urundeuva Fr. Allem. Anacardiaceae), com notas sobre a paquicalaza. Revista brasileira de sementes 21(1): 222-228.

4.1. Myracrodruon urundeuva Allemão, Trab. Comm. Sci. Expl. Bot. 1: 3. 1862.

Prancha 1, fig. O-Q ${ }^{2}$ e Prancha 2, fig. G-I.

Astronium urundeuva (Allemão) Engl., Bot. Jahrb. Syst. 1:45. 1881.

Nome popular: aroeira, urundeúva, urindeúva, aroeira-preta.

Árvores ou arvoretas, 2,5-20m, ramos jovens lenticelados, tricomas curtos ou longos, eretos ou oblíquos, retos ou levemente sinuosos, densos em direção ao ápice. Folhas 15,5-22cm, cartáceas; pecíolo não alado, 2,1-5cm, tricomas como nos ramos jovens; 
folíolos 9-13, geralmente opostos ou subopostos, sésseis ou peciolulados; peciólulos 1-5mm, no folíolo terminal 5-20mm; lâmina 3,4-6,6x1,7-4cm, no folíolo terminal 3,35,5×1,4-3,3cm, oval, largamente oval ou elíptica, ápice agudo, acuminado, obtuso ou mucronado, margem inteira ou irregularmente serrada na metade distal, base assimétrica, arredondada, cuneada, convexa ou truncada, faces adaxial e abaxial na nervura primária e margem com tricomas longos, eretos, levemente sinuosos ou sinuosos, densos, indumento alvo. Tirsóides axilares ou terminais, 4,5-17,3cm, creme-avermelhados; pedúnculo $0,5-2 \mathrm{~cm}$, tricomas geralmente longos, eretos, retos ou sinuosos, esparsos; brácteas 1,6-2,6×1,7-3mm, ovais, deltadas ou largamente deltadas, côncavas, escariosas, tricomas curtos, adpressos ou eretos, retos, densos na face abaxial; bractéolas vináceas, 0,4-1,7x0,2-0,8mm, ovais, deltadas ou lanceoladas, na margem com tricomas curtos ou longos, eretos ou oblíquos, retos ou sinuosos, esparsos. Flores: pedicelo inconspícuo; sépalas creme ou purpúreas, nas flores masculinas $0,8-1,4 \times 0,7-1,1 \mathrm{~mm}$, nas femininas ca. $1,5 \times 1,5 \mathrm{~mm}$, largamente ovais ou oblongas, côncavas, ápice arredondado ou obtuso, na margem com tricomas curtos ou longos, eretos, retos, esparsos; pétalas creme ou purpúreas, nas flores masculinas 1,6-2,5x1-1,3mm, nas femininas ca. 1,5×1 mm, ovais ou elípticas, ápice arredondado ou obtuso, tricomas como nas sépalas; estames nas flores masculinas 1,2-2,6mm, filetes espessos na base; estaminódios nas flores femininas 0,5-0,6mm; ovário ovóide, glabro. Drupas acastanhadas, 3-4,2mm diâm., glabras ou com tricomas curtos, eretos, retos, esparsos; sépalas obovadas, oblongas ou espatuladas, ampliadas até 4,56,5×2,6-4,2mm, glabras ou na margem com tricomas esparsos.

Myracrodruon urundeuva é a espécie mais amplamente distribuída do gênero, ocorrendo nos cerrados e caatingas das regiões nordeste, centro-oeste e sudeste do Brasil, e também nas formações chaquenhas da Bolívia, Argentina e Paraguai. B2, B3, B4, B5, B6, C2, C4, C5, C6, D4, D5, D6, D7: na floresta Estacional Semidecidual, matas ciliares, cerrados e áreas antropizadas; coletada com flores em abril, de junho a agosto e em outubro, e com frutos em janeiro, junho e de agosto a outubro. Fornece madeira de excelente qualidade, utilizada no passado como poste de rede elétrica. Devido ao histórico de exploração predatória intensiva deve ser categorizada como quase ameaçada (NT) no Estado de São Paulo, de acordo com os critérios utilizados por Souza et al. (2007).

Material selecionado: Agudos, I.1997, P.F. Assis 362 (BOTU). Bauru, VI.1991, M.K. Itoman 55 (SPSF). Bebedouro, VII.1930, A. Jordão s.n. (SPSF 6430). Cajuru, VII.1985, L.C. Bernacci 42 (SPF, UEC). Guaraçaí, VIII.1995, M.R. PereiraNoronha et al. 1610 (SP). Ilha Solteira, VIII.1995, M.R. Pereira-Noronha et al. 1382 (SP, SPF, UEC). Jaboticabal, VIII.1990, E.H.A. Rodrigues 51 (SP, UEC). Macedônia, 
VII.1978, H.F. Leitão-Filho et al. 8140 (UEC). Mogi-Guaçu, X.1993, R.R. Rodrigues et al. 102 (ESA, UNIP). Pedregulho, VII.1993, E.E. Macedo 148 (ESA, SPSF, UEC). Piracicaba, X.1989, E. Kampf 95 (ESA). Sabino, VII.1994, R.R. Rodrigues et al. 1 (ESA, HRCB, SPF, SPSF, UEC). Tanabi, VI.1994, J.Y. Tamashiro et al. 343 (HRCB, SP, SPF, SPSF, UEC).

Bibliografia adicional

Souza, V.C., Mamede, M.C.H., Cordeiro, I., Prado, J., Barros, F., Wanderley, M.G.L., Kageyama, P.Y., Ceccantini, G. \& Rando, J.G. 2007. Critérios uilizados na elaboração da Lista oficial de espécies da flora ameaçadas de extinção no Estado de São Paulo. In M.C.H. Mamede, V.C. Souza, J. Prado, F. Barros, M.G.L. Wanderley \& J.G. Rando (Org.). Livro vermelho das espécies vegetais ameaçadas do Estado de São Paulo. 1 ed. São Paulo: Instituto de Botânica, p. 15-20.

\section{Schinus L.}

Árvores ou arbustos, perenifólios; ramos inermes ou com ápice espinescente. Folhas simples ou compostas, imparipinadas ou paripinadas, geralmente cartáceas, pecioladas; raque alada ou estreitamente alada; folíolos opostos, subopostos ou alternos, margem inteira, crenada, sinuoso-dentada, sinuosocrenada, serrada ou crenado-serrada, base simétrica ou assimétrica, venação semicraspedródoma, craspedródoma ou cladódroma, nervura primária proeminente e secundárias geralmente planas nas faces adaxial e abaxial. Inflorescência axilar ou terminal, panícula ou pseudorracemo, pedunculada ou séssil; brácteas e bractéolas persistentes ou decíduas. Flores pediceladas, pedicelo articulado, 5-meras, unissexuais em plantas dióicas; sépalas conatas apenas na base; pétalas imbricadas; estames 10, obdiplostêmones, os antepétalos menores, inseridos entre os lobos do disco, anteras ovóides ou complanadas; estaminódios nas flores femininas 10, dotados de anteras, mas desprovidos de pólen; ovário 3-carpelar, 1-locular; óvulo lateral ou apical; estilete(s) 1-3; estigmas 3, capitados; pistilódio nas flores masculinas com óvulo abortivo; disco intraestaminal 10-lobado. Fruto drupa globosa; epicarpo fino, lustroso, separando-se quando maduro do mesocarpo negro e resinífero; endocarpo coriáceo; semente 1, complanada; cálice e estaminódios persistentes, resquícios de estigmas.

Gênero sul-americano, com aproximadamente 33 espécies, concentradas no norte da Argentina e estendendo-se ao Uruguai, ao longo dos Andes e Equador. Schinus é constituído por dois subgêneros caracterizados por uma combinação de 

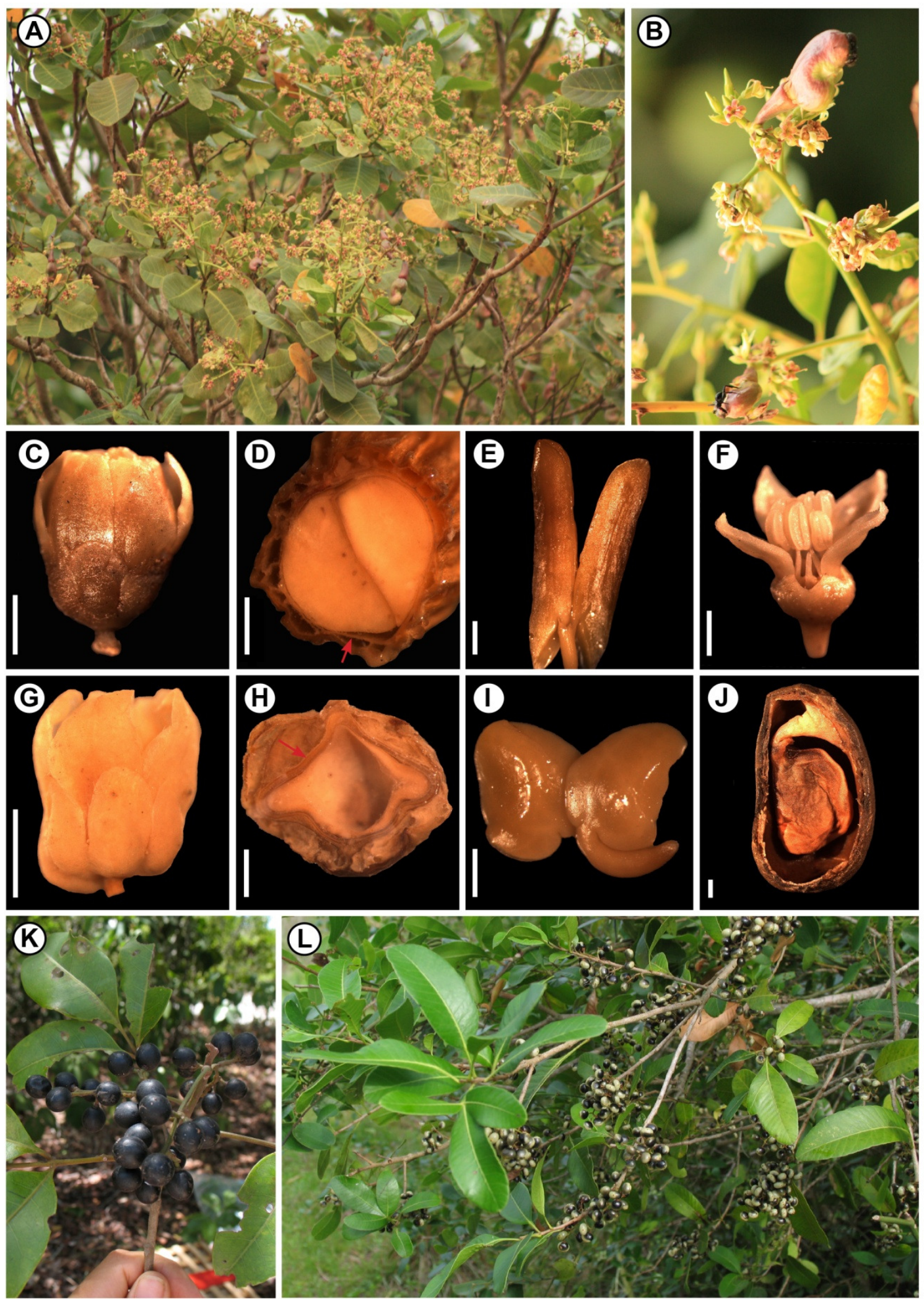

Prancha 2: A-B. Anacardium occidentale, A. hábito, B. ramo com flores e frutos imaturos. C-E. Astronium graveolens, C. flor masculina na antese, D. corte transversal do fruto mostrando o endocarpo fino e membranáceo ca. $0,025 \mathrm{~mm}$ (seta) e os cotilédones, E. embrião com cotilédones afastados em vista lateral. F. Lithrea molleoides, flor masculina na antese sem uma pétala. G-I. Myracrodruon urundeuva, G. flor masculina na antese, H. corte transversal do fruto mostrando o endocarpo espesso e coriáceo ca. 0,161 mm (seta), sem os cotilédones, l. embrião com cotilédones afastados em vista lateral. J-K. Tapirira guianensis, J. corte longitudinal do fruto, K. ramo frutífero. L. Lithrea brasiliensis, hábito. Fotos: A-B, C.M. Siniscalchi; C-J, C. L. Silva-Luz; K. J. H. El Ottra; L. G. Heiden. Escala: C-J=1 mm. 
caracteres, nem sempre consistentes, sendo que Euschinus apresenta folhas compostas pinadas e panículas compostas, e Duvaua geralmente folhas simples e pseudorracemos. Os táxons deste último subgênero, seção Euduvaua, apresentam delimitação de espécies ainda muito controvertida, sendo que Cabrera (1938) considerou muitos dos binômios já publicados sob S. polygamus (Cav.) Cabr. sensu lato, enquanto Barkley (1957) descreveu e reconheceu várias espécies distintas, sobretudo com base na morfologia da margem foliar. Porém observações recentes mostram que existem variações na margem da folha desse grupo relacionadas ao estádio de desenvolvimento, sendo que os indivíduos adultos geralmente apresentam margem inteira e os jovens ou plântulas, margem conspicuamente serrada ou dentada (Steibel \& Troiani 2008).

Barkley, F.A. 1944. Schinus L. Brittonia 5: 160-198.

Barkley, F.A. 1957b. A study of Schinus L. Lilloa 28: 5-110.

Steibel, P.E. \& Troiani, H.O. 2008. La identidade de Schinus fasciculatus var. arenicola y rehabilitación de S. sinuatus (Anacardiaceae). Bol. Soc. Argent. Bot. 43(1-2): 157-166.

\section{Chave para as espécies de Schinus}

1. Folhas simples; ramos terminando em um espinho; pecíolo não alado; inflorescência um pseudorracemo 1. S. engleri

1'. Folhas compostas imparipinadas; ramos inermes; raque e pecíolo alados ou estreitamente alados; inflorescência panícula.

2. Árvores ou arbustos $3-4 \mathrm{~m}$ alt.; margem dos folíolos irregularmente crenadoserrada, serrada na metade distal ou inteira; frutos 4-5mm diâm.

2. S. terebinthifolius

2'. Arbustos 0,2-1m alt.; margem dos folíolos sinuoso-dentada, sinuoso-crenada na metade distal ou inteira; frutos 5,1-8 mm diâm.

3. S. weinmannifolius

5.1. Schinus engleri F.A. Barkley, Brittonia 5: 178. 1944.

Prancha 3, fig. A-D e Prancha 4, fig. A-E.

Árvores ou arbustos, 2-8m alt., ramos pendentes com ápice espinescente, tricomas longos, eretos, às vezes adpressos, retos ou levemente sinuosos, densos, indumento alvo. Folhas simples, geralmente cartáceas; pecíolo não alado, 1-4 mm, tricomas longos ou curtos, eretos, retos ou sinuosos; lâmina 2,1-4,3×0,9-1,8cm, geralmente obovada, oval, elíptica, às vezes oblonga, ápice geralmente obtuso ou mucronado, margem geralmente inteira, às vezes irregularmente crenado-serrada ou serrada, levemente revoluta, base assimétrica ou simétrica, cuneada, face adaxial lustrosa, 
tricomas na nervura primária curtos, eretos ou adpressos, geralmente retos, esparsos, face abaxial com tricomas na nervura primária longos, eretos ou adpressos, retos ou sinuosos, esparsos. Pseudorracemos axilares, creme-esverdeados, sésseis, masculinos até 0,6-1cm, femininos ca. 0,5-0,7mm; brácteas 0,9-2,4x1-1,7mm, ovais, largamente ovais ou deltadas, nas margens com tricomas curtos, oblíquos, retos, densos; bractéolas geralmente 2, 0,9-1,5x0,3-0,8mm, lanceoladas, tricomas como nas brácteas. Flores: pedicelo verde ou verde-vináceo, 2,1-4,4mm, articulado a 1,5-3mm do cálice, tricomas longos, eretos, retos ou levemente sinuosos, esparsos, enlarguecido no ápice; sépalas verdes, 0,7-1,9x0,7-1mm, ovais, largamente ovais ou triangulares, ápice agudo ou obtuso, tricomas nas margens como nas brácteas; pétalas creme ou amarelo-esverdeadas, 2,2-3,2×1,1-2mm, ovais, obovadas ou oblongas, ápice arredondado ou obtuso, faces interna e externa glabras; estames nas flores masculinas antepétalos (0,9-)1,4-2,1 mm e antessépalos (1,3-)1,6-3,2mm; estaminódios nas flores femininas antepétalos $0,7 \mathrm{~mm}$, antessépalos $1 \mathrm{~mm}$; ovário ovóide, esverdeado, glabro. Drupas rosadas ou vermelhas, 4-5,3mm diâm., glabras.

Schinus engleri ocorre desde o sudeste do Brasil até o Uruguai. D8, D9: restrita a poucas localidades, na floresta Ombrófila Mista Alto-Montana, geralmente na borda da mata, próxima aos cursos dos rios. Comumente observa-se o desenvolvimento de larvas de insetos formando galhas arredondadas nos ramos. Coletada com flores de julho a setembro, com frutos de outubro a dezembro.

Material selecionado: Campos do Jordão, VIII.2011, C.L. Silva-Luz et al. 161 (SP, NY, CTES, SPF). São José do Barreiro, IX.2010, H. Serafim 448 (SPF).

Schinus engleri possui inflorescência aparentando ser um racemo, porém suas flores pediceladas portam bractéolas e uma bráctea conspícua na base, o que evidencia uma estrutura ramificada muito contraída (címula), constituindo, portanto, um pseudorracemo. Por esse caráter, a espécie contrasta muito com as demais Schinus de São Paulo, que apresentam inflorescência muito ramificada, do tipo panícula. A distinção entre S. engleri e S. ramboi F.A. Barkley, táxons similares, é complicada devido à sobreposição entre os caracteres vegetativos e reprodutivos. $O$ estudo morfológico de ampla amostragem, incluindo os materiais-tipo, somado à distribuição geográfica coincidente, aponta que talvez esses táxons sejam conspecíficos. Embora ainda não seja possível propor a sinonimização, no presente trabalho já foi adotado o uso do binômio mais antigo. 
5.2. Schinus terebinthifolius Raddi, Mem. Mat. Fis. Soc. Ital. Sci. Modena, Pt. Mem.

Fis. 18(2): 399-400. 1820.

Prancha 3, fig. F-G.

Nome popular: aroeira-vermelha, aroeira-mansa.

Árvores, 3-4m, ramos inermes, lenticelados, glabros ou com tricomas curtos ou longos, eretos, retos ou sinuosos no ápice, esparsos. Folhas (5,8-)7,3-18,8(-30,5)cm, compostas, imparipinadas, cartáceas; pecíolo estreitamente alado, (1-)1,9-4,5(-5,3)cm, tricomas curtos ou longos, adpressos, eretos ou oblíquos, geralmente retos, esparsos; raque estreitamente alada; folíolos 5-13(-15), opostos ou subopostos, geralmente sésseis; lâmina (1,9-)2,6-5,6x(0,8-)1-2,5cm, no folíolo terminal (2,9-)3,4-6,6(-11,1)x1,12,4cm, obovada, oval, oblonga, elíptica ou largamente elíptica, ápice obtuso ou agudo, às vezes mucronado, margem inteira, irregularmente crenado-serrada ou serrada na metade distal, levemente revoluta, base assimétrica, cuneada, decurrente, côncava ou convexa, ambas faces glabras ou com tricomas curtos, adpressos, eretos ou oblíquos, geralmente retos, esparsos, principalmente na nervura primária. Panículas axilares ou terminais, creme-esverdeadas, masculinas $7,3-13 \mathrm{~cm}$, congestas, femininas $2,5-5,7 \mathrm{~cm}$, laxas; pedúnculo 0,5-3,3cm, tricomas como nos ramos; brácteas 1-1,7×0,7-1,3mm, deltadas, tricomas curtos, oblíquos, retos, esparsos, conspícuos na margem; bractéolas $0,7 \times 0,3 \mathrm{~mm}$, deltadas ou lanceoladas, tricomas como nas brácteas. Flores: pedicelo verde, 1-2,2mm, articulado a $0,6 \mathrm{~mm}$ do cálice, enlarguecido no ápice, tricomas como no pedúnculo; sépalas verdes, 0,6-1,1×0,6-1,2mm, largamente ovais, ápice arredondado ou obtuso, ambas faces glabras,margem glabra ou com tricomas esparsos, conspícuos; pétalas creme, 1,6-2,5×0,8-1,5mm, oblongas, obovadas ou ovais, ápice arredondado ou obtuso, ambas faces glabras; estames nas flores masculinas antepétalos $0,9-1,8 \mathrm{~mm}$ e antessépalos 2,2-2,9mm; estaminódios nas flores femininas 0,6-0,9mm; ovário globoso ou irregularmente globoso, glabro. Drupas rosadas ou vermelhas, 4-5mm diâm., glabras ou com tricomas curtos, esparsos.

Schinus terebinthifolius é amplamente distribuída pela América tropical e subtropical, ocorrendo desde restingas e margem de manguezais até florestas Ombrófila Densa, Alto-Montana e Semidecídua de altitude, e áreas antropizadas. D3, D5, D6, D7, D8, D9, E5, E6, E8, E9, F4, F5, F6, F7, G6: nas florestas Estacional Semidecidual e Ombrófilas Densa de Terras Baixas a Densa Alto-Montana, restingas, matas de encostas e matas ciliares. Coletada com flores de janeiro a abril e de junho a dezembro, e com frutos de janeiro a julho e de setembro a novembro. É usada em arborização urbana e nas etapas inicias de reflorestamento de áreas perturbadas. Tem sido amplamente utilizada na culinária nacional e internacional, pois suas sementes, conhecidas como pimenta-rosa, apresentam um sabor suave e levemente apimentado. 
Material selecionado: Bananal, III.1977, P.E. Gibbs et al. 4598 (UEC). Botucatu, IV.1996, R. Montanholi 145 (UEC). Cachoeira Paulista, I.1987, J. Augusto s.n. (R 185555). Campinas, I.2004, E. Ikemoto 49 (UEC). Cananéia, V.1990, P. Martuscelli 1038 (SP, SPF). Cunha, III.1994, J.B. Baitello 566 (SP, SPF, SPSF, UEC). Ilha Comprida, V.1999, N. Hanazaki \& Z. Barbosa 119 (UEC). Itanhaém, IV.2009, C. Moura et al. 273 (SPSF). Itapeva, I.1996, V.C. Souza et al. 10582 (ESA, HRCB, SP, SPF, UEC). Itararé, II.2000, F. Barros 3009 (RB, SP, SPF). Itatiba, III.2003, E.R. Passarin \& L. Mickeliunas 1056 (UEC). Jacupiranga, II.1995, A. Sartori 33426 (HRCB, SPF, UEC). Monte Alegre do Sul, III.1995, L.C. Bernnaci et al. 1216 (IAC). São Miguel Arcanjo, IV.2002, S. Bortoleto et al. 73 (ESA, UEC). Tarumã, IV.1994, G. Durigan 31682-A (UEC). Ubatuba, V.2007, I. Sazima 302 (UEC).

Schinus terebinthifolius apresenta variação morfológica considerável em relação aos folíolos, principalmente na forma, tamanho, número, margem e ápice. Baseado nas estruturas vegetativas, Engler (1876) propôs seis variedades, enquanto que Barkley (1957), na revisão do gênero, reconheceu apenas quatro delas. As análises morfológicas dos espécimes não apontam caracteres consistentes que definam bem todas essas variedades, e estudos morfoanatômicos e fisiológicos demonstram que Schinus terebinthifolius apresenta grande plasticidade morfológica em resposta aos habitats com diferentes condições lumínicas (Sabbi et al. 2010), dessa maneira o tratamento a nível infraespecífico parece inviável. As populações das restingas podem ser diferenciadas das populações de outras formações vegetacionais por apresentarem geralmente 5(-7-9) folíolos de (3,2-)4,9-10x(1,7-)2,2-3,3.

Bibliografia adicional

Sabbi, L.B.C., Ângelo, A.C. \& Boeger, M.R. 2010. Influência da luminosidade nos aspectos morfoanatômicos e fisiológicos de folhas de Schinus terebinthifolius Raddi (Anacardiaceae) implantadas em duas áreas com diferentes graus de sucessão, nas margens do Reservatório Iraí, Paraná, Brasil. Iheringia, Bot. 65(2): 171-181.

5.3. Schinus weinmannifolius Mart. ex Engl. in Mart. \& Eichler, FI. bras. 12(2): 385. 1876.

Prancha 3, fig. E-E ${ }^{2}$ e Prancha 4, fig. F-I.

Nome popular: aroeira-rasteira, aroeira-do-campo.

Arbustos, $0,2-1 \mathrm{~m}$, ramos inermes, pouco ramificados, glabros ou raramente com tricomas longos ou curtos, eretos, levemente sinuosos ou retos, esparsos. Folhas 4,6$15 \mathrm{~cm}$, compostas, imparipinadas, cartáceas; pecíolo alado, 0,5-1,8cm, glabro; raque alada; folíolos 7-21, opostos, subopostos ou alternos, sésseis; lâmina 1,1-3,3×0,4-1cm, 
no folíolo terminal 1,5-2,2×0,6-0,9cm, elíptica, lanceolada, oblanceolada, oval ou obovada, ápice acuminado ou agudo, margem sinuoso-dentada ou sinuoso-crenada na metade distal ou inteira, levemente revoluta, base assimétrica, cuneada ou convexa, no folíolo terminal decurrente, face adaxial glabra ou raramente na nervura primária com tricomas longos, eretos, às vezes curtos, adpressos, levemente sinuosos, esparsos, face abaxial glabra. Panículas axilares, creme-esverdeadas, masculinas até $2,7-5 \mathrm{~cm}$, femininas $2 \mathrm{~cm}$; pedúnculo $0,7-1,9 \mathrm{~cm}$, glabro; brácteas 1,3$2,1 \times 0,4-0,8 \mathrm{~mm}$, lanceoladas, glabras ou com tricomas curtos, oblíquos, retos, esparsos; bractéolas, geralmente 2, 0,7-1,1 $\times 0,3-0,6 \mathrm{~mm}$, lanceoladas, glabras ou com tricomas como nas brácteas. Flores: pedicelo verde, 1,2mm, articulado ca. $1 \mathrm{~mm}$ do cálice, enlarguecido no ápice, tricomas curtos, eretos, retos, esparsos; sépalas verdes, 1,1-1,3×0,7-0,9mm, ovais, ápice agudo, glabras; pétalas creme, 1,7-2,6×0,7-1mm, obovadas ou oblongas, ápice arredondado, glabras; estames nas flores masculinas antepétalos ca. $1,8 \mathrm{~mm}$ e antessépalos $2,4 \mathrm{~mm}$; estaminódios nas flores femininas 0,8 1,1mm; ovário ovóide, glabro. Drupas vermelhas, 5,1-8mm diâm., glabras.

Schinus weinmannifolius ocorre nos campos e cerrados do sul, sudeste e centro-oeste do Brasil, no Uruguai, Paraguai e nordeste da Argentina. E4, E5, E6, F4, F5: nos cerrados e campos. Coletada com flores de novembro a dezembro, com frutos de novembro a janeiro.

Material selecionado: Capão Bonito, XII.1966, J. Mattos 14876 (SP). Itaberá, XII.1966, J. Mattos 14298 (SP). Itapetininga, I.1950, J. Lima s.n. (RB 69444). Itararé, IX.1989, C.A.M. Scaramuzza \& V.C. Souza 598 (ESA). Tatui, I.1918, Hoehne s.n. (SP 1443).

A margem dos folíolos de Schinus weinmannifolius apresenta variações consideráveis, sendo que em um mesmo espécime é possível observar a margem totalmente inteira, sinuoso-dentada ou sinuoso-crenada na metade distal.

\section{Spondias L.}

Árvores, perenifólias; ramos inermes. Folhas compostas, imparipinadas, adensadas em direção ao ápice, membranáceas, cartáceas ou coriáceas, pecioladas; raque não alada; folíolos opostos, subopostos ou alternos, margem inteira, crenada ou serrada, base assimétrica ou simétrica, venação semicraspedródoma ou craspedródoma, nervura primária levemente proeminente e secundárias planas na face adaxial, nervura primária proeminente e secundárias levemente proeminentes ou planas na face abaxial, nervura intramarginal presente. Inflorescência axilar ou terminal, panícula, congesta, pedunculada; brácteas e bractéolas persistentes ou decíduas. Flores pediceladas, pedicelo articulado, geralmente 5-meras, bissexuais ou 
unissexuais em plantas dióicas ou poligamodióicas, fortemente protândricas; sépalas conatas apenas na base; pétalas valvares; estames (8-)10, obdiplostêmones, desiguais, entre os lobos do disco, anteras ovóide-complanadas; ovário 3-5-carpelar, 3-5-locular; óvulo apical; estiletes 3-5; estigmas 3-5, capitados ou oblíquo-capitados; disco intraestaminal 10-crenado ou ondulado. Fruto drupa complanada, globosa, obovóide ou elipsóide; epicarpo amarelo-alaranjado, vermelho-arroxeado ou esverdeado; mesocarpo carnoso; endocarpo coriáceo, fibroso ou espinescente; semente(s) 1-5, complanada, embrião curvo.

Gênero com aproximadamente 16 espécies, exibindo distribuição disjunta na região Neotropical e na Ásia tropical. Nas Américas, ocorrem cerca de oito espécies do México ao sul do Brasil. Spondias mombin L., S. purpurea L. e S. dulcis Parkinson são espécies cultivadas pantropicalmente. Os frutos destas e outras espécies de Spondias, conhecidos no Brasil como cajá, cajá-manga, umbu e taperebá entre outros, são comestíveis e consumidos regionalmente.

Mitchell, J.D. \& Daly, D.C. 1998. The "tortoise's cajá" - A new species of Spondias (ANACARDIACEAE) from southwestern Amazonia. Brittonia 50(4): 447-451.

Prancha 3. A-D. Schinus engleri, A. ramo frutífero; $A^{1}$. detalhe do indumento no ramo; $B$. inflorescência; B1. detalhe do pedicelo mostrando a bráctea, as bractéolas e o pedicelo articulado; C. androceu, sem pistilódio; D. gineceu, estaminódios e disco intraestaminal, sem perianto. $E-E^{2}$. Schinus weinmannifolius, $E-E^{2}$. variação das folhas e raque; $E$. ramo florífero; $E^{1}$. ramo frutífero; $E^{2}$. folha. $F-G$. Schinus terebinthifolius, $F-F^{1}$. variação foliar; F. ramo florífero; $F^{1}$. folha; G. ramo frutífero. H-J ${ }^{1}$. Spondias mombin, H. ramo florífero; I. detalhe da nervura intramarginal dos folíolos; J. flor bissexual; $J^{1}$. gineceu e disco intraestaminal; K-N ${ }^{1}$. Tapirira obtusa, K. ramo florífero; L. detalhe do indumento nas nervuras da face abaxial do folíolo; $M$. flor feminina na antese; N. fruto; $\mathrm{N}^{1}$. detalhe do indumento do fruto. $\mathrm{O}-\mathrm{R}$. Tapirira guianensis, $\mathrm{O}$. flor masculina na antese; $\mathrm{O}^{1}$. pistilódio e disco intraestaminal; $\mathrm{P}$. flor feminina, sem duas sépalas e duas pétalas; Q. gineceu; R. corte longitudinal do fruto. (A-A ${ }^{1}$. Lima 1144; B-C. Silva-Luz 161; D. Silva-Luz 165; E. Barreto 3211; E1. Mattos 14298; E². Lima RB 69444; F. Jung 427; $F^{1}$-G. Bernacci 1428; H-I. Moraes 2; K-L. Hoehne SPF 13548; M-N¹. Nicolau 1797; O. Tomasulo 42; P-Q. Hoehne 13939; R. Bernacci 722). Ilustrações: Klei Rodrigo Sousa. 


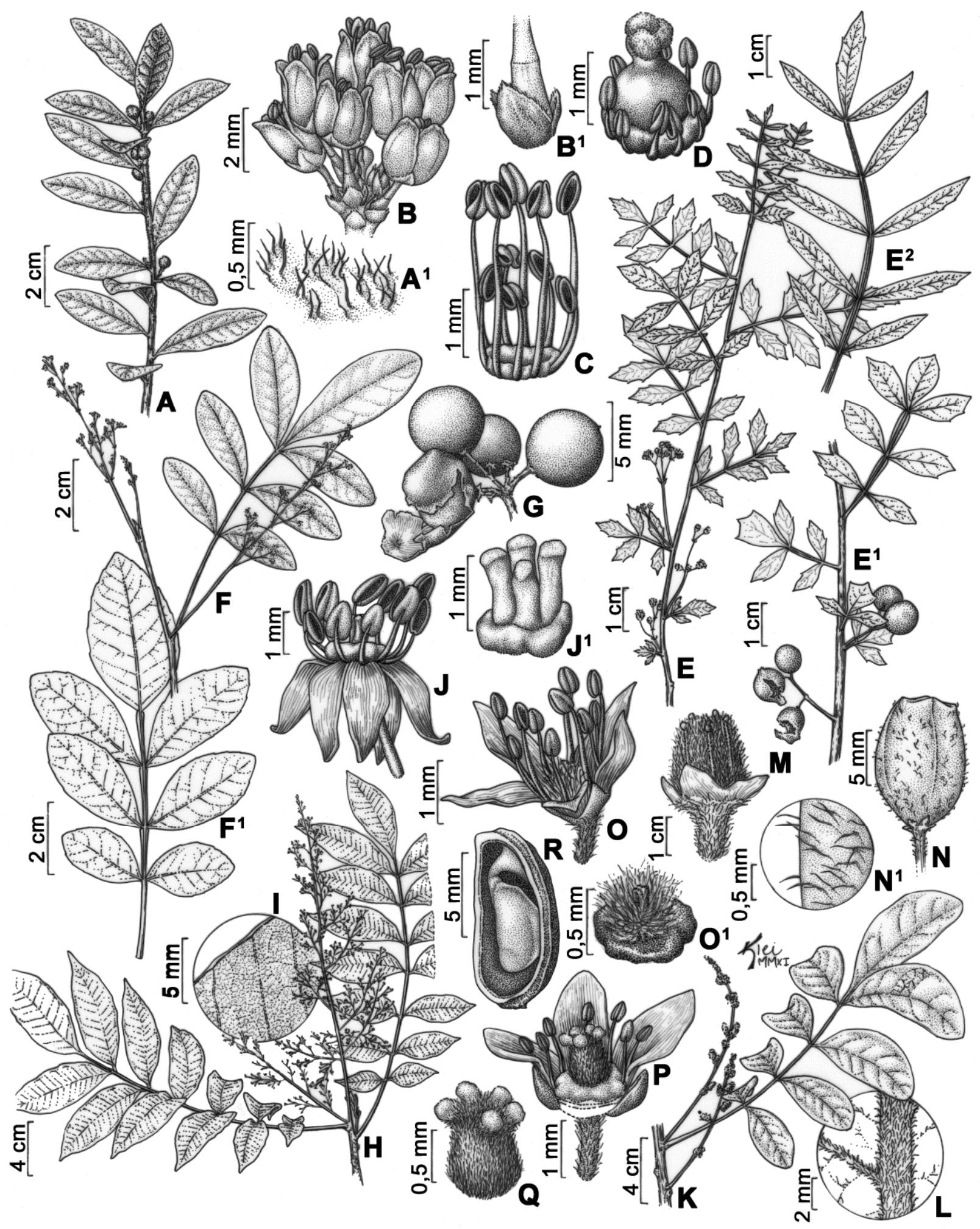


1. Spondias mombim L., Sp. pl. 1: 200. 1753.

Prancha 3, fig. $\mathrm{H}-\mathrm{J}^{1}$.

Spondias lutea L., Sp. pl. 2: 613. 1762.

Nome popular: cajá-mirim.

Árvores, 6-20m, ramos jovens lenticelados, glabros ou com tricomas curtos, eretos, retos, esparsos, às vezes, longos, sinuosos, densos. Folhas 17,1-32cm, compostas, imparipinadas, cartáceas ou membranáceas; pecíolo não alado, $3,5-10 \mathrm{~cm}$, tricomas como nos ramos jovens, intumescidos nos nós com tricomas longos, eretos, sinuosos, densos; folíolos 7-17, alternos ou subopostos, peciolulados; peciólulos 2-4mm, o do folíolo terminal $8-25 \mathrm{~mm}$, tricomas longos ou curtos, eretos, retos ou levemente sinuosos, esparsos, às vezes densos; lâmina $5-13,3 \times 1,7-3,5 \mathrm{~cm}$, no folíolo terminal 6,610x2,1-4,4cm, oval, oblonga ou elíptica, ápice longo-acuminado, margem inteira, ondulada, base assimétrica, cuneada, decurrente, côncava ou convexa, faces adaxial e abaxial na nervura primária e margem com tricomas curtos, eretos, retos, esparsos. Panículas axilares ou terminais, amarelo-esverdeadas ou creme, 25,5-32,5cm; pedúnculo 1,2-5,5cm, tricomas como nos ramos jovens; brácteas 1,5-3,5×0,4-0,5mm, lanceoladas ou lineares, às vezes deltadas, tricomas como nos ramos jovens, decíduas; bractéolas 0,5-0,6×0,4mm, geralmente deltadas, tricomas curtos, oblíquos, retos, decíduas. Flores bissexuais com pedicelo 3,2-3,3mm, articulado a 2,2-2,4mm do cálice, tricomas como nas brácteas; sépalas inconspícuas, 0,1-0,5×0,5-0,6mm, deltadas, ápice agudo ou acuminado, ambas faces com tricomas curtos, oblíquos, retos, esparsos; pétalas amarelo-esverdeadas ou creme, 2,2-3,6×1,1-1,4mm, ovais ou obovadas, reflexas, ápice agudo, glabras; estames antepétalos 2-3,1 $\mathrm{mm}$ e antessépalos 2-4,2mm; ovário ovóide, glabro. Drupas obovóide-complanadas ou ovóides, amarelas ou amarelo-alaranjadas, 22-38×13-25mm, lenticeladas, glabras.

Spondias mombin ocorre no sul do México, da América Central e Antilhas até América do Sul tropical. É característica da floresta Ombrófila Densa na Amazônia (matas de terra firme), florestas Estacionais Semideciduais, matas ciliares e formações secundárias. B2, C1: nas florestas Estacionais Semideciduais e matas ciliares próximas ao rio Paraná. Coletada com flores em outubro e novembro.

Material selecionado: Castilho, $21^{\circ} 04^{\prime 2} 29,5^{\prime \prime} S, 51^{\circ} 35^{\prime} 15,8^{\prime \prime W}, 13 . X .1998$, L.R.H. Bicudo 275 (UFMS). Pres. Epitácio, XI.1992, I.Cordeiro et al. 1169 (SPF).

Material adicional examinado: GOIÁS, Campinaçu, X.1991, T.B. Cavalcanti s.n. (SPF 79842). MATO GROSSO, Minaçu, I.1998, B.M.T. Walter s.n. (SPF 134837). MATO GROSSO, Poconé, X.1985, W. Thomas et al. 46233 (INPA, NY, SPF). MATO GROSSO, Rondonópolis, II 1974, G. Hatschbach 34111 (MBM, SPF). TOCANTINS, Arraias, XI.1994, G. Hatschbach 60365 (MBM, SPF). 

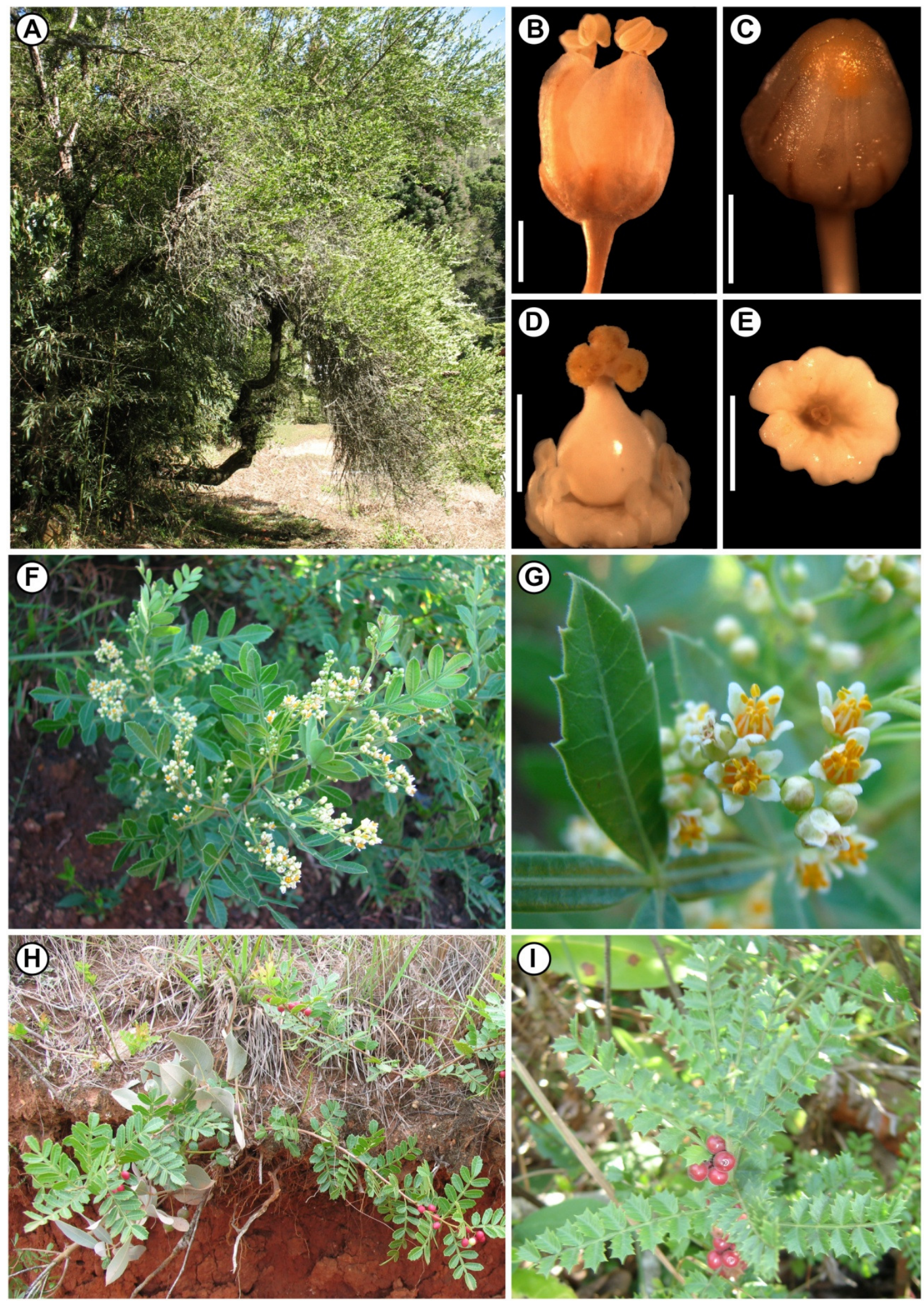

Prancha 4: A-E. Schinus engleri, A. hábito, B. flor masculina na antese, C. botão floral feminino, D. gineceu, estaminódios e disco intraestaminal sem perianto, E. disco intraestaminal e pistilódio; F-I. Schinus weinmannifolius, F. ramos floríferos, G. detalhe das flores masculinas, H-I. ramos frutíferos. Fotos: A-E, C.L. Silva-Luz; F-I, G. Heiden. Escala: B-E= 1mm. 


\section{Tapirira Aubl.}

Árvores ou arbustos, perenifólios; ramos inermes. Folhas compostas, imparipinadas, cartáceas, pecioladas; raque não alada; folíolos subopostos ou opostos, margem inteira, ondulada, base assimétrica, venação broquidródoma, nervura primária proeminente atenuando-se no ápice nas faces adaxial e abaxial, nervuras secundárias impressas na face adaxial e impressas ou proeminentes na face abaxial. Inflorescência axilar ou terminal, panícula, pedunculada; brácteas e bractéolas persistentes ou decíduas. Flores pediceladas, pedicelo não articulado, 5meras, unissexuais em plantas dióicas ou poligamodióicas; sépalas conatas na base, subcarnosa; pétalas imbricadas; estames 10, obdiplostêmones, os antepétalos menores, inseridos entre os lobos do disco, anteras elipsóides; estaminódios nas flores femininas 10, dotados de anteras com pólen inviável; ovário 4-5-carpelar, 1locular; óvulo apical ou subapical; estiletes 4-5, curtos; estigmas (4)5, capitados; pistilódio nas flores masculinas, com óvulo abortivo; disco intraestaminal 10-lobado. Fruto drupa carnosa, ovóide ou ovóide-complanada, epicarpo negro ou roxo; mesocarpo resinífero; endocarpo coriáceo; semente 1, embrião curvo; cálice persistente; resquícios de estigmas.

Gênero neotropical, com cerca de oito espécies, distribuído desde o sul do México até o sul do Brasil, Bolívia e Paraguai.

Barford, A.S. 1999. A new species of Tapirira (Anacardiaceae) from Ecuador. Novon 9 (4): 472-475.

Mitchell, J.D. 1997. Anacardiaceae. In A.R.A. Görts-Van Rijn (eds.) Flora of the Guianas - Series A: Phanerogams 19(129): 1-79.

Wendt, T. \& Mitchell, J.D. 1995. A new species of Tapirira (Anacardiaceae) from the Isthmus of Tehuantepec, Mexico. Brittonia 47(2): 101-108.

\section{Chave para as espécies de Tapirira}

1. Ramos jovens e inflorescências com tricomas curtos, adpressos, retos, esparsos; nervura primária da face abaxial dos folíolos glabra ou com tricomas retos, esparsos, indumento translúcido; ovário ovóide-complanado; drupa glabra ou com tricomas curtos, geralmente adpressos, retos

1. T. guianensis

1'.Ramos jovens e inflorescências com tricomas longos, adpressos ou eretos, retos ou levemente sinuosos, geralmente densos, às vezes esparsos, persistentes ou decíduos; nervura primária da face abaxial dos folíolos com tricomas geralmente sinuosos, densos, indumento ferrugíneo; ovário ovóide; drupa com tricomas longos, eretos ou adpressos, sinuosos

2. T. obtusa 
7.1. Tapirira guianensis Aubl., Hist. PI. Guiane 1: 470, t. 188. 1775.

Prancha 2, fig. J-K e Prancha 3, fig. O-R.

Nome popular: pau-pombo, fruto-de-pomba, tabucuva, cupiúba, copiúva.

Árvores ou arbustos, 2-20m, ramos jovens com tricomas curtos, adpressos, retos, esparsos, glabrescentes. Folhas 15-26,5cm; pecíolo não alado, (1-)2,5-6,5cm, tricomas como nos ramos jovens; folíolos (3-)5-11, opostos ou subopostos, peciolulados; peciólulos 1-3(-5)mm, o do folíolo terminal 6-17mm; lâmina 6,4-15,5x1,2$9,3 \mathrm{~cm}$, elíptica, oblonga, ou obovada, ápice acuminado, às vezes retuso, base cuneada ou decurrente, face adaxial glabra, brilhante, face abaxial glabra ou com tricomas curtos ou longos, adpressos, retos, esparsos, indumento translúcido na nervura primária. Panículas axilares, amarelo-esverdeadas, tricomas geralmente curtos, adpressos ou oblíquos, retos ou levemente sinuosos, masculinas $9-19 \mathrm{~cm}$, femininas 6,3-8cm; pedúnculo 1,5-4cm, tricomas como nos ramos jovens; brácteas $1,7 \times 0,5 \mathrm{~mm}$, lanceoladas ou ovais; bractéolas $0,5-0,8 \times 0,2-0,5 \mathrm{~mm}$, lanceoladas ou ovais, tricomas densos, indumento translúcido. Flores: pedicelo 0,5-1,4mm, tricomas curtos, adpressos, oblíquos ou eretos, retos ou sinuosos, densos; sépalas verdes, 0,3$1(-1,5) \times 0,4-1(-2,2) \mathrm{mm}$, largamente ovais ou orbiculares, ápice arredondado ou obtuso, face adaxial glabra, face abaxial tricomas curtos, adpressos, retos ou levemente sinuosos, esparsos; pétalas alvo-amareladas ou alvo-esverdeadas, (0,9-)1,2-1,8(2,5) x0,7-1,2(-1,4)mm, lanceoladas ou ovais, ápice obtuso, face adaxial glabra, face abaxial glabra ou com tricomas esparsos como nas sépalas; estames nas flores masculinas antepétalos 0,7-1,8mm e antessépalos 1,1-1,8(-2,4)mm; estaminódios nas flores femininas 0,7-1mm; ovário ovóide-complanado, tricomas longos, adpressos, sinuosos, densos. Drupas verdes ou castanhas, ovóide-complanadas, 8-10×3,9-6mm, glabras ou com tricomas curtos, geralmente adpressos, retos, esparsos.

Tapirira guianensis é a espécie de Anacardiaceae neotropical mais amplamente distribuída, ocorrendo tanto nas florestas de terras baixas e baixomontanas da América do Sul como na América Central. No Brasil, é encontrada em várias formações vegetacionais da Amazônia, em matas ciliares, em florestas pluviais do nordeste, sudeste e sul, e em formações secundárias sobre solo úmido. B2, B3, B4, B6, C1, C2, C3, C5, C6, C7, D1, D3, D4, D5, D6, D7, D8, E4, E5, E6, E7, E8, E9, F4, F5, F6, G6: nas florestas Ombrófilas Densa Aluvial, Densa de Terras Baixas, Densa Submontana e Densa Montana e Estacional, matas ciliares, restingas e cerrados. Espécie regularmente com duas florações anuais (Warming 1908, Pirani 1987); coletada com flores de janeiro a abril e de junho a dezembro, e com frutos de janeiro a março e de maio a dezembro. Produz frutos atrativos da fauna e possui 
tolerância higromórfica, por isso é indicada para reflorestamentos heterogêneos de áreas degradadas, principalmente de locais úmidos.

Material selecionado: Adamantina, IX.1995, L.C. Bernacci et al. 1994 (IAC, SP, UEC). Aguaí, X.1994, L.S. Kinoshita 12/94 (HRCB, SP, SPF, UEC). Álvares Florence, 2119'S 4954'W, XI.1994, M.R. Silva 1377 (SPF). Bauru, III.1998, L.C. Miranda 414 (SP). Botucatu, V.1984, L.M. Braga et al. 28 (SPSF). Cajuru, XII.1999, S.A. Nicolau et al. 1800 (SP, SPSF). Cananéia, II.1995, A. Sartori 32634 (ESA, SP, SPF, UEC). Capão Bonito, X.1996, K.D. Barreto et al. s.n. (ESA 87086). Iguape, 2447'S 4742'W, I.1999, D. Sampaio et al. 59 (ESA, SPSF). Ilhabela, VI.2000, J.B. Baitello 1768 (SPSF). Cunha, II.1994, P.E.G. Coutinho (SPSF 17455). Itaberá, I.1996, V.C. Souza et al. 10565 (ESA, SPF, UEC). Itararé, 2404'50"S, 4912'19”W, XII.1997, F. Chung 82 (ESA, IAC, SPSF, UEC). Itirapina, II.1994, J.Y. Tamashiro \& J.C. Galvão 413 (HRCB, SP, SPF, SPSF). Jaboticabal, XI.1990, E.H.A. Rodrigues 112 (SP). Jales, X.1951, W. Hoehne s.n. (SPF 13939). Paraguaçu Paulista, X.1994, G.A.D.C. Franco 1279 (HRCB, SP, SPF, SPSF, UEC). Paranapanema, 23ํ31'22”'S 4846'21'W, XII.2007, R. Cielo-Filho et al. 573 (SPSF). Paulo de Faria, X.1994, A.L. Maestro 69 (HRCB, SP, SPF). Penápolis, X.1981, J.R. Pirani 131 (SPF). Pereira Barreto, XI.1985, L.P.M. Fonzar 172 (HRCB, SP). Presidente Epitácio, II.1996, J.P. Souza et al. 370 (ESA, SP, UEC). São José do Rio Pardo, XII.1994, L.S. Kinoshita \& A. Sartori 10/94 (ESA, HRCB, SP, SPF, UEC). São Paulo, 2339'47'S 4646’21'W, X.1992, R.J.F. Garcia 193 (PMSP, SPF). Teodoro Sampaio, X.1985, O.T. Aguiar 140 (SPF, SPSF).

Engler (1876) reconheceu em Tapirira guianensis três variedades, baseadas, sobretudo na forma e dimensões dos folíolos; contudo, a análise dos espécimes de diversas localidades apenas no âmbito do Estado de São Paulo já mostra grande variabilidade nos folíolos e parece inviável a aplicação de nomes às formas variantes discretas.

Bibliografia adicional

Warming, E. 1908. Lagoa Santa. Imprensa Official do Estado de Minas Gerais. Belo Horizonte. 
7.2. Tapirira obtusa (Benth.) J.D. Mitch., Novon 3: 66. 1993.

Prancha 2, fig. K-N ${ }^{1}$.

Mauria obtusa Benth., J. bot. Kew gard. misc. 4:16. 1852.

Tapirira marchandii Engl. in Mart. \& Eichler, FI. bras. 12(2): 379. 1876.

Tapirira peckoltiana Engl. in Mart. \& Eichler, FI. bras. 12(2): 379. 1876.

Nome popular: pau-pombo, peito-de-pomba.

Árvores $8-15 \mathrm{~m}$, ramos jovens com tricomas longos, adpressos ou eretos, retos ou levemente sinuosos, normalmente densos, às vezes esparsos, persistentes ou decíduos, indumento ferrugíneo. Folhas 17-26,5cm; pecíolo não alado, 2-6cm, tricomas como nos ramos jovens; folíolos 5-9, opostos ou subopostos, peciolulados; peciólulos 1-3mm, no folíolo terminal 4-10mm; lâmina 5,5-12,5×2,1-4,8cm, elíptica, oblonga, obovada ou oval, ápice acuminado ou obtuso, às vezes agudo, base cuneada ou decurrente, face adaxial com tricomas longos, adpressos ou eretos, sinuosos, esparsos, face abaxial com tricomas longos, adpressos ou eretos, geralmente sinuosos, densos, principalmente na nervura primária, indumento ferrugíneo nas nervuras. Panículas axilares, amareladas ou alvo-esverdeadas com tricomas como nos ramos jovens, masculinas 14,5-17cm, femininas $7 \mathrm{~cm}$; pedúnculo 1,8-3,7cm, tricomas longos, eretos, sinuosos, densos, indumento ferrugíneo; brácteas 1,7×0,5mm, lanceoladas ou ovais; bractéolas $1 \times 0,7 \mathrm{~mm}$, ovais, tricomas como no pedúnculo. Flores: pedicelo $1,2-1,8 \mathrm{~mm}$, tricomas como no pedúnculo; sépalas verdes, 0,70,9x0,9-1,2mm, suborbiculares ou largamente ovais, ápice obtuso, face adaxial glabra, face abaxial com tricomas esparsos; pétalas alvo-amareladas, 1,5-2,0x0,7-1mm, ovais ou lanceoladas, ápice agudo ou obtuso, face adaxial glabra, face abaxial glabra ou com tricomas curtos esparsos; estames nas flores masculinas antepétalos $0,7 \mathrm{~mm}$ e antessépalos 1,5-2mm; estaminódios nas flores femininas 1,2-1,5mm; ovário ovóide, com tricomas curtos, oblíquos ou eretos, retos ou levemente sinuosos, densos, indumento ferrugíneo. Drupas marrons ou castanho-escuras, globosas ou ovóidecomplanadas, 7-13×6-12mm, tricomas longos, eretos ou adpressos, sinuosos, esparsos ou densos, indumento ferrugíneo, persistentes ou decíduos.

Tapirira obtusa distribui-se na região tropical da América do Sul; no Brasil, ocorre nas formações vegetacionais da Amazônia, florestas pluviais do sudeste, cerrado e mata ciliar da região centro-oeste, sendo pouco expressiva no nordeste. C6, D6, D7, D9, E7, E8, F5: nas florestas Ombrófilas Densa de Terras Baixas a Densa Montana e Estacional, matas ciliares e cerrados. Coletada com flores de agosto a novembro, e com frutos de janeiro a março e de setembro a novembro. É indicada nos reflorestamentos heterogêneos de áreas degradadas por apresentar frutos muito aprecidos pela avifauna 
Material selecionado: Cajuru, X.1999, S.A. Nicolau et al. 1797 (SP, SPF). Capão Bonito, XI.1909, A. Lofgren 1494 (SP). Joanópolis, IX.1979, H.F. Leitão-Filho et al. 10399 (UEC). Jundiaí, III.1986, R.R. Rodrigues \& L.P.C. Morelatto s.n. (ESA, SPF 79335). Loreto, A. Leme s.n. (SPSF 4690). São José do Barreiro, 2010, E. Martins et al. 167 (SPF). São José dos Campos, X.1985, A.F. Silva 1261 (RB, UEC).

Tapirira obtusa é muito semelhante à T. guianensis, sendo diferenciadas essencialmente por meio da forma e pilosidade do ovário e densidade de tricomas no fruto maduro. Normalmente os ramos e as nervuras da face abaxial dos folíolos de T. obtusa possuem tricomas densos e indumento ferrugíneo, porém, alguns espécimes apresentam essas estruturas com tricomas esparsos como ocorre em T. guianensis.

Bibliografia adicional

Mitchell, J.D. 1993. Tapirira obtusa comb. nov. (Anacardiaceae). Novon 3(1): 66.

\section{Lista de exsicatas}

Aguiar, O.T.: 140 (7.1); Amarante, E.: SPF 72981 (5.1); Andrade, P.R.: MBM 29912 (3.1); Assis, P.F.: 362 (4.1), 259 (4.1); Augusto, J.: R 185555 (5.2); Baitello, J.B.: 203 (2.1), 566 (5.2), 695 (3.1), 1768 (7.1); Barreto, K.D.: 1765 (3.1), 3462 (3.1), 3211 (5.3), ESA 87086 (7.1); Barros, F.: 3009 (5.2); Batalha, M.A.: 677 (1.1); Bazarian, S.V.: 35 (5.2); Bernnaci, L.C.: 42 (4.1), 270 (2.1), 1216 (5.2), 1428 (5.2), 722 (7.1), 1994 (7.1); Bortoleto, S.: 73 (5.2); Braga, L.M.: 28 (7.1); Carvalho, J.P.M.: SPSF 7894 (5.1), SPSF 7954 (5.1); Cavalcanti, T.B.: SPF 79842 (6.1); Ceccantini, G.C.T.: 2164 (5.2); Cesar, O.: 214 (1.1); Chaddad-Junior, J.: 250 (2.1); Cielo-Filho, R.: 573 (7.1); Cipolla, L.: SP 14542 (4.1); Chung, F.: 82 (2.1); Cordeiro, I.: 1169 (6.1); Coutinho, P.E.G.: SPSF 17455 (7.1); De Grande, D.A.: 64 (5.2); Dombrowski, L.T.: 5492 (3.1); Dreveck, S.: 22 (3.1); Durigan, G.: 31682-A (5.2), UEC 77913 (3.1); Farney, C.: 4657 (3.1); Fonseca, M.L.: 5882 (1.2); Fonzar, L.P.M.: 172 (7.1); Franco, G.A.D.C.: 1279 (7.1); Gandolfi, S.: 365 (2.1); Garcia, R.J.F.: 193 (7.1), 260 (5.2); Gaudichaud, C.: 925 (3.1); Gibbs, P.E.: 4598 (5.2); Godoy, S.A.P.: 583 (5.2); Goes, M.: SPF 145095 (5.2); Gomes, J.C.: 2622 (5.2); Grotta, A.S.: 259 (1.1); Guedes, C.R.F.: 6 (5.2); Guerin, N.: 160 (1.1); Hanazaki, N.: 119 (5.2); Hatschbach, G.: 34812 (1.1), 80 (3.1), 72492 (3.1), 34111 (6.1), 60365 (6.1); Hoehne, F.C.: SP 1443 (5.3), SP 8714 (5.1); Hoehne, W.: 12536 (1.1), SPF 12453 (1.1), SPF 13939 (7.1); SPF 13548 (7.2); Ikemoto, E.: 49 (5.2); Itoman, M.K.: 55 (4.1); Ivanauskas, N.M.: SPF 201247 (2.1), 6111 (3.1); Jaccond.: 69 (4.1); Jordão, A.: SPSF 6430 (4.1); Jorge, S.O.: SPF 165799 (1.2); Jung, S.L.: 427 (5.2); Kampf, E.: 95 (4.1); Kiehl, J.: 
5199 (3.1); Kinoshita, L.S.: 10/94 (7.1), 12/94 (7.1); Kirizawa, M.: 922 (5.2), 2190 (5.2); Kuhlmann, M.: 2130 (5.1), SP 32398 (5.1), SPF 83487 (2.1); Labouriau, M.S.: 111 (1.1); Leitão-Filho, H.F.: 478 (2.1), 8140 (4.1), 10399 (7.2); Leme, A.: SPSF 4690 (7.2); Lima, H.C.: 1144 (5.1); Lima, J.: RB 58080 (5.3), RB 69444 (5.3); Loebmann, G.M.: SPF 201238 (1.2); Lofgren, A.: 1494 (7.2), 1827 (3.1); Macedo, E.E.: 148 (4.1); Maestro, A.L.: 77 (3.1), 69 (7.1); Mantovani, W.: 843 (1.1); Marcondes-Ferreira, W.: 1056 (7.1); Martins, E.: 167 (7.2); Martuscelli, P.: 1038 (5.2); Mattos, J.: 9566 (5.3), 14298 (5.3), 14363 (5.1), 14524 (5.3), 14733 (5.1), 14876 (5.3), 15020 (5.1), SP 111921 (5.3); Mattos, J.R.: 16265 (1.2); Miranda, L.C.: 414 (7.1); Miyagi, P.H.: 383 (5.2); Montanholi, R.: 145 (5.2); Moraes, E.A.: 2 (6.1); Moura, C.: 273 (5.2); Naranjo, E.J.L.: 102 (1.1); Nicolau, S.A.: 1797 (7.2), 1800 (7.1); 1813 (7.2); Paschoal, M.E.S.: 2471 (1.1); Passarin, E.R.: 1056 (5.2); Pereira-Noronha, M.R.: 1328 (3.1), 1382 (4.1), 1610 (4.1); 1633 (1.1); Pickel, B.: SPSF 2580 (1.2); Pinheiro, M.H.O.: 118 (3.1); Pirani, J.R.: 2892 (1.2), 2670 (1.2), 4516 (1.2), 649 (3.1), 131 (7.1); Polisel, R.T.: 318 (5.1); Queiroz, L.P.: 2504 (5.1), 2524 (5.1); Robim, M.J.: 8775 (3.1), SPSF 8694 (5.1); Rocha, Y.T.: ESA 33296 (1.1); Rodrigues, E.H.A.: 51 (4.1), 112 (7.1); Rodrigues, R.R.: 1 (4.1), 102 (4.1), SPF 79335 (7.2); Romão, G.O.: 1828 (3.1); Rossi, L.: 224 (5.2); Ruffino, P.H.P.: 133 (3.1); Sakuragui, C.M.: 488 (3.1); Saite, Y.: 439 (3.1); Sampaio, D.: 59 (7.1); Sanches, C.D.: 23 (5.2); Sartori, A.: 32634 (7.1), 33426 (5.2); Sasaki, D.: 680 (3.1), 776 (1.1); Sazima, I.: 302 (5.2); Scaramuzza, C.A.M.: 531 (1.1), 598 (5.3); Serafim, H.: 118 (7.1), 448 (5.1); Simão-Bianchini, R.: 153 (5.1); Silva, A.F.: 1261 (7.2); Silva, G.P.: 520 (1.2); Silva, M.R.: 1377 (7.1); Silva-Luz, C.L.: 161 (5.1.), 165 (5.1); Souza, J.P.: 370 (7.1); Souza, V.C.: 7101 (3.1), 7103 (5.3), 10565 (7.1); 10582 (5.2); Sugiyama, M.: 640 (5.2); Tamashiro, J.Y.: 343 (4.1), 413 (7.1), 708 (3.1); Thomas, W.: 46233 (6.1); Toledo-Filho, L.C.: 26032 (2.1); Tomasulo, L.B.: 42 (7.1); Tozzi, A.M.G.A.: 58 (3.1); Venturelli, M.: SPF 78304; Walter, B.M.T.: SPF 134837 (6.1); Xavier, S.: 74 (5.1); Zickel, S.: 30270 (2.1).

\subsection{Estado de conservação e distribuição geográfica das espécies}

De acordo com estudo da distribuição geográfica das Anacardiaceae do Estado de São Paulo, Lithrea brasiliensis é a única espécie ameaçada, tendo sido categorizada como presumivelmente extinta (EX) no Estado. Com exceção do material-tipo, coletado em 1833, não há registros ulteriores desse táxon no Estado, inserindo-se no critério "ausência de novos registros nos últimos 50 anos, inclusive em condições ex-situ". As informações imprecisas sobre a procedência do espécime-tipo de $L$. brasiliensis podem levar ao questionamento da sua efetiva ocorrência no Estado. Porém, existem registros antigos da espécie em Minas Gerais também, coletados por 
Gaudichaud e Saint Hilaire, sem coletas recentes. Portanto, a ausência atual dessa espécie em São Paulo e Minas Gerais pode ser o resultado de extinção local das populações, que talvez fossem pequenas e escassas e acabaram sendo eliminadas localmente com a destruição e diminuição de habitats. A modificação da paisagem natural geralmente ocorre pela ação antrópica, sendo a restinga ameaçada principalmente pela especulação imobiliária e pela a expansão da malha viária; o cerrado, equivocadamente, considerado no passado de qualidade inferior, teve sua área muito reduzida, cedendo lugar à agropecuária; a Floresta Estacional, devido ao porte robusto e riqueza, foi fortemente explorada e reduzida a fragmentos que se encontram isolados e empobrecidos (Nalon et al. 2008). A ausência de Lithrea brasiliensis em São Paulo não parece ser resultante de lacunas de coletas, pois extensivos trabalhos de campo já foram realizados na maior parte do Estado, incluindo grandes projetos como a Flora Fanerogâmica do Estado de São Paulo, entre muitos outros levantamentos florísticos e fitossociológicos. Tampouco parece ser o resultado de falta de identificações acuradas, pois L. brasiliensis é uma espécie facilmente reconhecida por apresentar folhas com nervura marginal conspícua e frutos do tipo drupa, esverdeados ou verde-cinéreos. O padrão de distribuição atual de $L$. brasiliensis é disjunto (figura 5), com populações em Cabo Frio no Rio de Janeiro, e as demais populações nos Estados da região sul do Brasil, no Uruguai e na Argentina. É reportado que ao norte e a leste de Cabo Frio forma-se uma vegetação mais seca e decídua com características xerófilas devido aos baixos índices pluviométricos (Hueck 1972, Dantas et al. 2009). Sob condições ambientais extremas, principalmente ventos fortes, ocorre nessa região uma formação decidual com cactáceas colunares, por isso, essa vegetação já foi classificada como uma disjunção fisionômica da caatinga (Ururahy et al. 1987). Essa disjunção também pode ser interpretada como uma extensão das matas secas do interior do país, que se aproximam da costa nessa região de baixa pluviosidade, interrompendo a faixa de mata pluvial da costa oriental do Brasil (Pennington et al. 2004). L. brasiliensis é uma espécie característica e preferencial de capões dos campos do Planalto Meridional, porém ocorre ainda com bastante frequência nas restingas e de forma rara e pouco frequente na Floresta Ombrófila Densa e na Floresta Estacional Decidual do Alto Uruguai (Fleig 1989). Dessa maneira, a ocorrência descontínua (sudeste e sul) de Lithrea brasiliensis nas restingas poderia ser o resultado da ação antrópica, como já foi mencionado, ou outra hipótese seria a rota de migração NE-SW (Oliveira-Filho \& Ratter 1995). Esta rota, relíquia de uma Floresta Decídua mais expressiva, conectava as caatingas do nordeste às Florestas Semidecíduas no sudeste do Brasil e sul do Paraguai (Prado \& Gibbs 1993), e devido a mudanças climáticas essa faixa retraiu-se, restando 
atualmente apenas fragmentos como o encontrado em Cabo Frio, e consequentemente, a população de Lithrea brasiliensis teria ficado isolada nesse município.

Embora Myracrodruon urundeuva tenha sido categorizada como vulnerável (VU) por Mamede et al. (2007), os dados de herbários ora compilados mostram que esta espécie é afetada somente no critério "histórico de exploração predatória". De acordo com os critérios estabelecidos para categorização do estado de conservação das espécies do Estado de São Paulo, para que um táxon seja considerado vulnerável é necessário que exiba suscetibilidade segundo três ou mais critérios, por isso, Myracrodruon urundeuva é classificada no presente trabalho como "quase ameaçada" (NT). As demais espécies de Anacardiaceae que ocorrem no Estado receberam a categorização de "preocupação menor" (LC), conforme mostra a tabela 3.

Figura 5: Distribuição de Lithrea brasiliensis $(\boldsymbol{\Delta})$ e de Lithrea molleoides (•) no Estado de São Paulo. As populações de $L$. brasiliensis do Rio de Janeiro apresentam folhas obovadas com ápice truncado ou emarginado; enquanto os espécimes do sul do Brasil, Argentina e Uruguai possuem folhas geralmente oblongas com ápice mucronado.

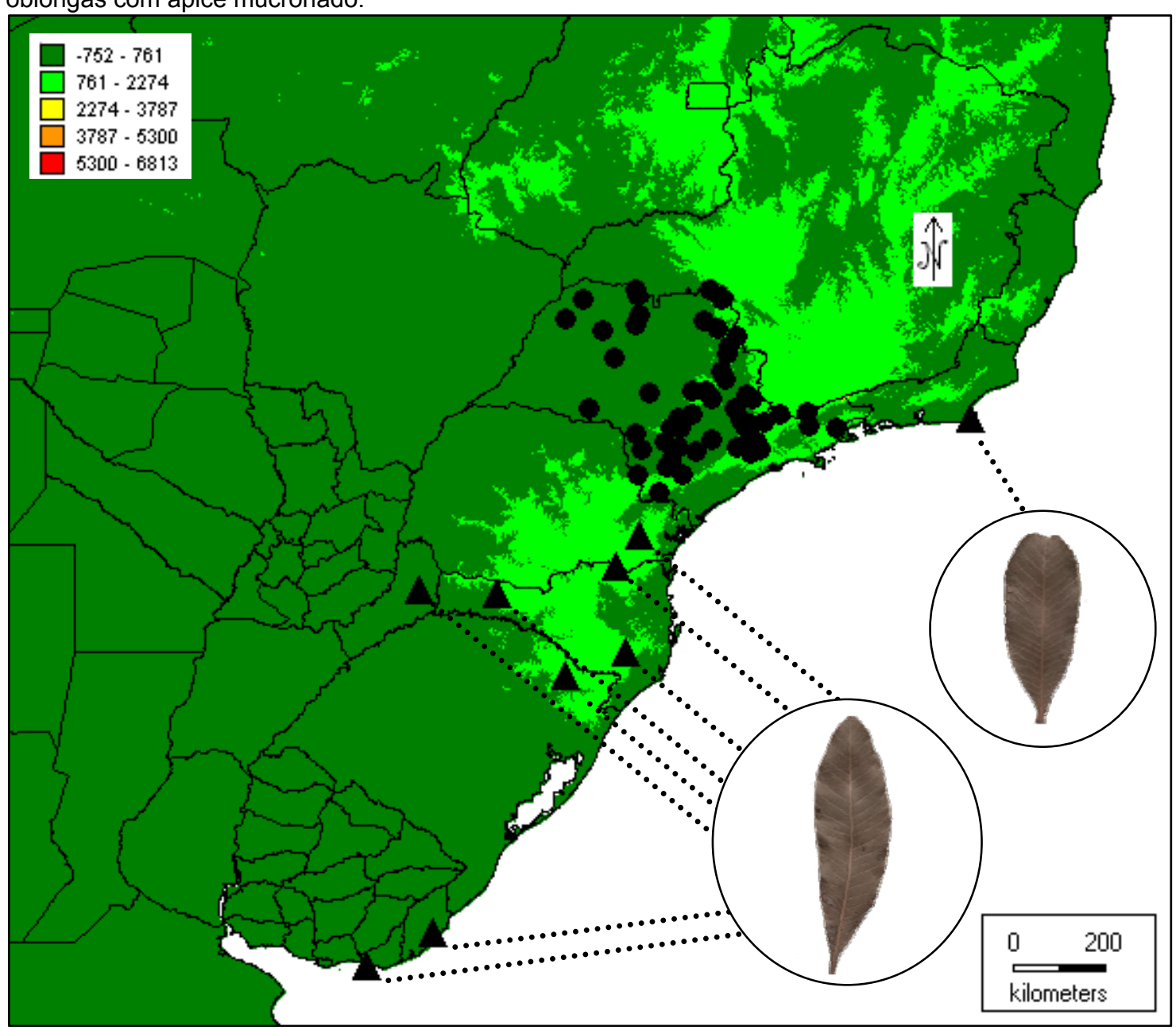




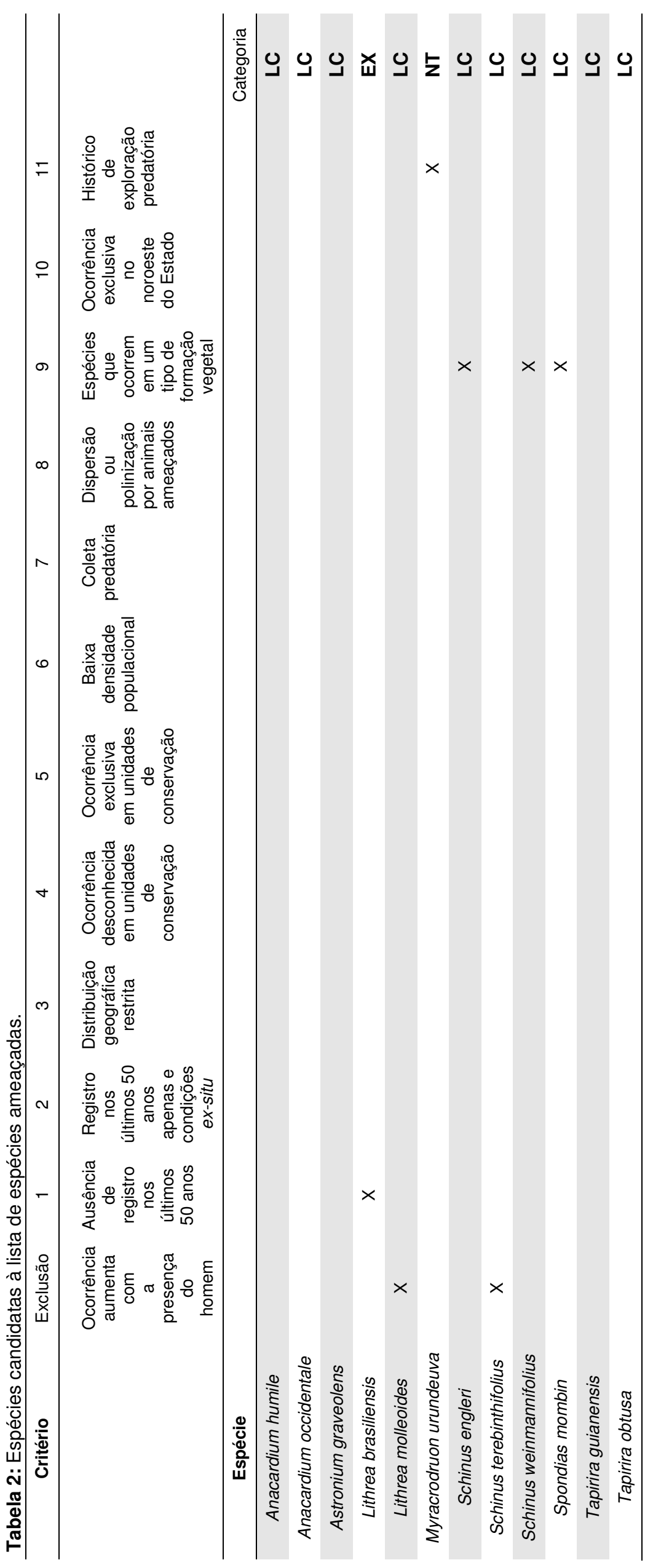


Schinus engleri é encontrada, no Estado de São Paulo, nas florestas Ombrófila Mista Alto-Montana de Campos do Jordão e da Serra da Bocaina (tabela 4, figura 6). A floresta Ombrófila Mista, formação caracterizada pela presença de Araucaria e que representa um relicto no domínio da Mata Atlântica, distribui-se de forma contínua desde a porção central do Rio Grande do Sul ao sul do Estado de São Paulo, reaparecendo em manchas disjuntas nas elevações mais altas das serras da Mantiqueira e da Bocaina, no nordeste do Estado de São Paulo, e avançam sobre o sul de Minas Gerais (Hueck 1972, Mantovani 2003), sendo tais regiões coincidentes com a distribuição total de Schinus engleri (figura 6). De acordo com levantamento bibliográfico e o estudo das coleções herborizadas, com exceção de Campos do Jordão, esta espécie ainda não havia sido registrada para outros municípios do Estado, sendo registrada recentemente em Areias, na Serra da Bocaina. A ocorrência desse táxon parece estar relacionada com a altitude elevada, pois embora o Núcleo Curucutu do Parque Estadual da Serra do Mar, região com altitude entre 750-850 m, apresente similaridade florística com a formação campestre de Campos de Jordão e/ou Itatiaia (Garcia \& Pirani 2005), não há registros de Schinus engleri para essa área. É possível que essa espécie ocorra também na orla de matas das regiões de altitudes elevadas de outros municípios da Serra da Bocaina e da Mantiqueira.

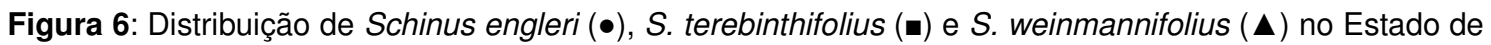
São Paulo.

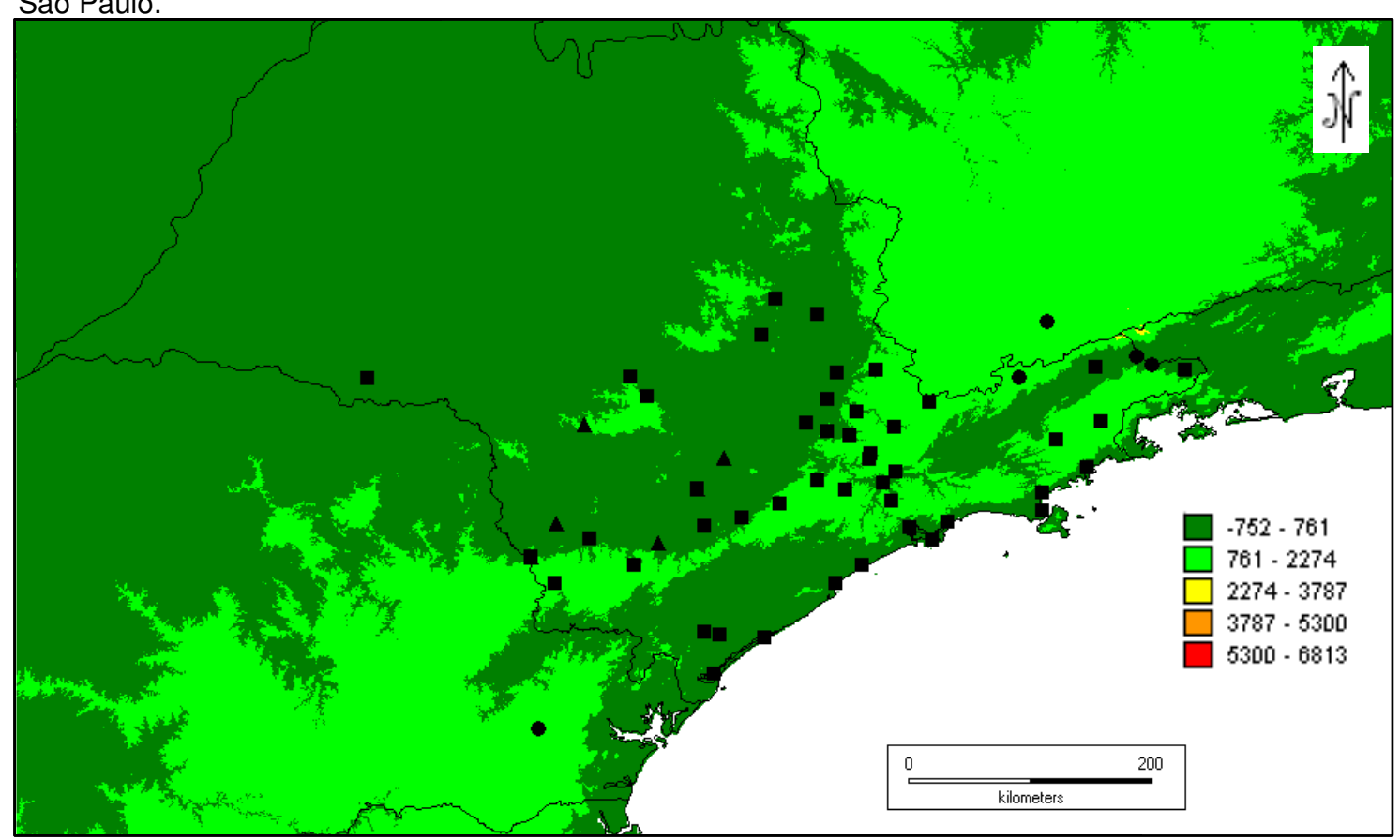


Schinus weinmannifolius ocorre nos cerrados e campos de Itararé e Itapeva, entre outros municípios localizados próximos à região sul-sudoeste do Estado de São Paulo (tabela 4, figura 6). Essas formações savânicas estendem-se até a região adjacente de Jaguariaíva, no Paraná, e constituem as áreas mais meridionais de cerrado do país. A espécie distribui-se para o sul bem além dessas áreas, ocupando até as formações campestres do Rio Grande do Sul, denominadas genericamente de pampas ou campanha gaúcha. A maioria das coleções disponíveis dessa espécie oriundas do Estado de São Paulo são antigas (entre 1918-1967) e a mais recente data de 1994. Com o objetivo de buscar informações sobre suas populações e seu estado de conservação no Estado de São Paulo, expedições a campo foram realizadas nos municípios com registro dessa espécie, porém sem sucesso. A vegetação desses municípios encontra-se consideravelmente impactada, sendo que a paisagem que predomina nessas regiões são as plantações de pinheiro e de eucalipto. Isso se deve principalmente ao fato de que a política científica e de conservação não tem conferido a atenção adequada aos campos subtropicais úmidos (Pillar 2006). Além disso, esses campos são remanescentes da porção norte dos campos do Planalto Meridional que, no passado, recobriam o Arco de Ponta Grossa até o sul do Estado do Paraná. Este tipo de formação apresenta condições climáticas e edáficas favoráveis para a expansão da Floresta Ombrófila Mista (Pillar 2003). Entretanto, este processo de regressão das áreas de campos tem sido estabilizado devido à ação do fogo (Pillar \& Quadros 1997). A implementação de florestamentos em diversas áreas ao longo do Arco de Ponta Grossa e a eliminação da prática do fogo tem causado impacto nos campos, como a invasão de pinheiros (Pinus) e a mudança em sua fisionomia (Scaramuzza 2007). Schinus weinmannifolius não atendeu ao número de critérios necessários para ser categorizada como espécie ameaçada, porém de acordo com os resultados desse estudo é possível perceber que as populações da espécie estão em declínio no Estado. São poucos os estudos sobre a caracterização florística dos campos do Estado de São Paulo (Usteri 1911, Joly 1950b, Garcia \& Pirani 2005, Scaramuzza 2007), porém esses dados são suficientes para mostrar que, apesar desses campos abrangerem um território reduzido, eles possuem uma flora rica, principalmente os de Itararé, que possuem uma riqueza de espécies elevada, contendo muitos táxons inéditos e ameaçados de extinção para o Estado de São Paulo (Scaramuzza 2007). Além disso, esses estudos evidenciam que essas áreas têm sofrido mudanças na paisagem devido à ação antrópica e por isso, mais esforços são necessários a fim de assegurar a conservação desses remanescentes de campos. 
Figura 7: Distribuição de Astronium graveolens ( $\mathbf{\Delta})$, Myracrodruon urundeua (घ) e Spondias mombin $(\bullet)$ no Estado de São Paulo.

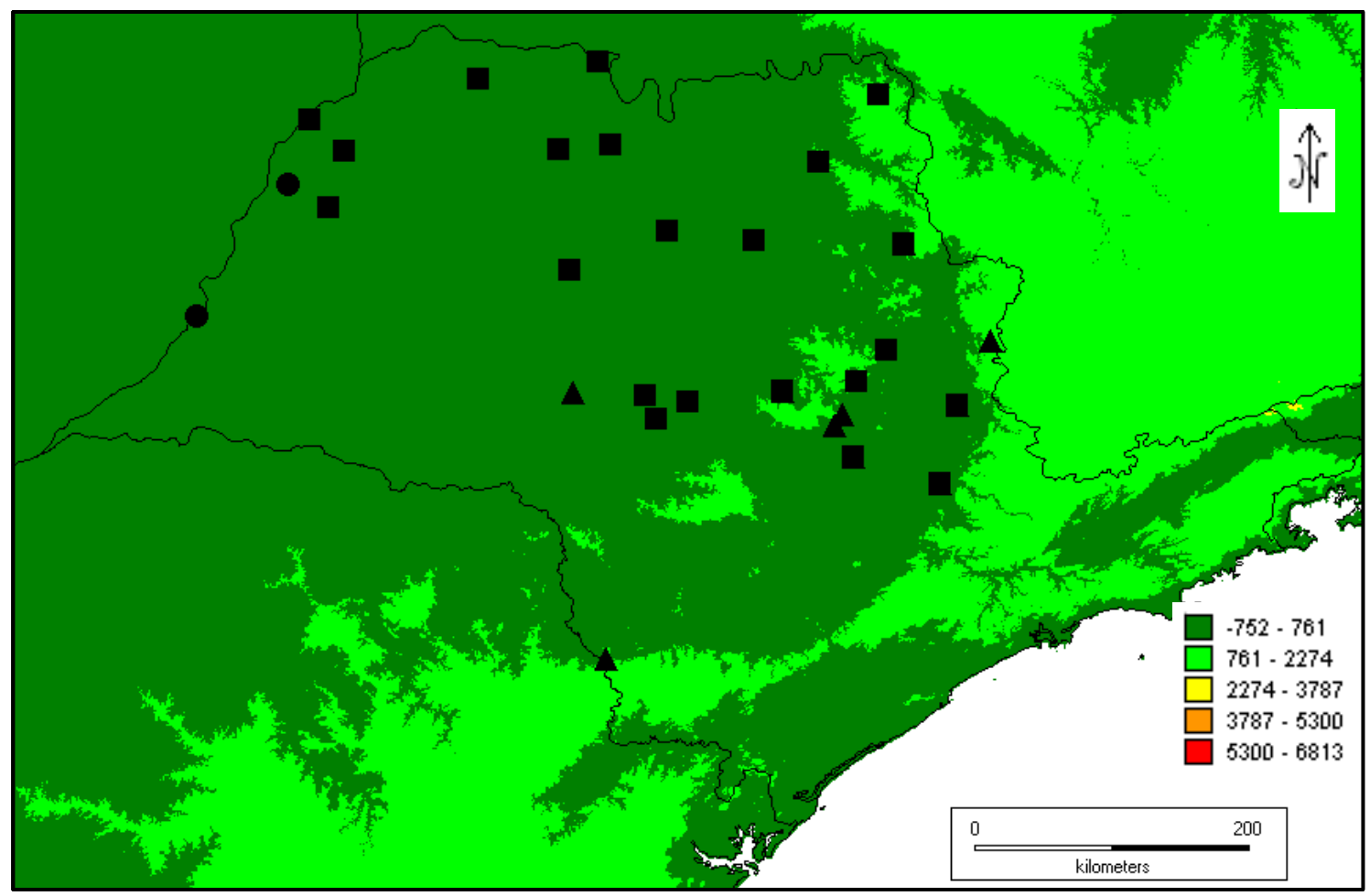

Astronium graveolens e Myracrodruon urundeuva, assim como a maioria das espécies de Anacardiaceae, ocorrem nas Florestas Estacionais Semideciduais e nos cerrados do Estado de São Paulo (tabela 3, figura 7). Essas formações compreendem áreas do Estado que têm sofrido muitos impactos ambientais, e isto explica, consequentemente, o número relativamente alto de espécies que ocorrem em áreas antropizadas (figura 10).

Spondias mombin não foi registrada no Estado de São Paulo no Catálogo de Plantas e Fungos do Brasil (Silva-Luz \& Pirani 2010), sendo escassos os estudos taxonômicos sobre esse gênero, assim como dados acerca da sua distribuição geográfica. A análise das coleções de Anacardiaceae depositadas nos herbários do Estado contribuiu para ampliar os dados de distribuição dessa espécie, sendo que no Estado de São Paulo, Spondias mombin apresenta distribuição restrita, ocorrendo somente na Floresta Estacional do oeste e noroeste do Estado (figura 7). É possível que o número de registros dessa espécie esteja subestimado (coletas somente em dois municípios), pois essas regiões do Estado de São Paulo ainda possuem lacunas de coleta, sendo indicadas como áreas prioritárias para levantamentos da fauna e flora (Metzger \& Rodrigues 2008). Spondias mombin apresenta frutos comestíveis, por isso é comumente cultivada em outras regiões. 
Anacardium humile ocorre nos cerrados paulistas, enquanto Anacardium occidentale possui distribuição restrita às restingas (figura 8). As demais espécies, Lithrea molleoides (figura 5), Schinus terebinthifolius (figura 6) e Tapirira guianensis (figura 9) são as espécies mais amplamente distribuídas da família no Estado de São Paulo, sendo encontradas em quase todas as formações vegetacionais, inclusive em áreas antropizadas (tabela 4). Tapirira obtusa é uma espécie comum, porém ocorre com menos freqüência do que $T$. guianensis, não sendo encontrada na restinga e Floresta Ombrófila Densa Aluvial, assim como também não existe registro para áreas antropizadas. No Brasil, Tapirira guianensis é amplamente distribuída em todo território brasileiro, principalmente em terrenos úmidos (Oliveira Filho \& Ratter 1995), sendo um elemento importante do estrato lenhoso de matas do Brasil Central (Silva Júnior et al. 1998). Entre os táxons da familia que ocorrem nas fitofisionomias da Mata Atlântica é possível citar Schinus terebinthifolius, Tapirira guianensis e Tapirira obtusa (figura 10). Do ponto de vista ecológico, essas espécies são indicadas em reflorestamentos heterogêneos de áreas degradadas por apresentar frutos atrativos da fauna, além disso Tapirira guianensis possui capacidade de tolerar áreas úmidas (Lorenzi 2008).

Devido à sua posição geográfica, o Estado de São Paulo apresenta padrões biogeográficos interessantes (Wanderley et al. 2006). Algumas espécies de Anacardiaceae podem ocorrer nas regiões norte, nordeste e/ou centro-oeste do Brasil e têm o seu limite sul nos Estados do Rio de Janeiro e de Minas Gerais. É o caso de Thyrsodium spruceanum Benth., Anacardium nanum A. St.-Hil., Astronium concinnum Schott., Astronium nelson-rosae Santin, Cyrtocarpa caatingae J.D. Mitch. \& Daly, Schinopsis brasiliensis Engl., Spondias macrocarpa Engl. e Spondias venulosa (Engl.) Engl. Astronium glaziovii Mattick ocorre na região sudeste, nos Estados de Minas Gerais e Rio de Janeiro, porém não é registrada para o Estado de São Paulo. Em relação à sua distribuição, é importante mencionar que foi encontrado um exemplar dessa espécie (Francisca, R 73545) no herbário do Museu Nacional, coletado no Estado de São Paulo. Na ficha desse exemplar é citado "Porangaba" como local de coleta. De acordo com o protólogo dessa espécie, entre os materiais analisados está o exemplar do herbário citado acima, coletado por Freire Allemão (Mattick 1934), por isso, o nome "Francisca" que consta na etiqueta dessa exsicata deve ser retificado para "Francisco", cujo nome completo é Francisco Freire Allemão e Cysneiros. Ao buscar mais informações sobre o local da coleta desse exemplar, foi possível constatar por meio das biografias de Freire Allemão (Mello Moraes 1874, Morais 2005), que ele não teria realizado coletas botânicas no Estado de São Paulo, e que a localidade citada na ficha de coleta dessa exsicata também é errônea, pois 
"Porangaba" trata-se certamente do sítio Porangaba, localizado no bairro conhecido atualmente como Mendanha, Rio de Janeiro.

Outras espécies têm o seu limite sul no Estado de São Paulo, tais como Anacardium occidentale, Myracrodruon urundeuva, Spondias mombin e Tapirira obtusa. Esse padrão de distribuição com limite sul no Estado de São Paulo também é compartilhado por espécies de outras famílias, tais como Apocynaceae (Forsteronia australis Müll. Arg. e F. pubescens A. D.C.), Asclepiadacceae (Matelea orthosioides (E. Fourn.) Fontella), Oxalidaceae (Oxalis physocalyx Zucc. ex Prog. e O. umbraticola A. St.-Hil.), Rhamnaceae (Gouania corylifolia Raddi) e Velloziaceae (Vellozia tubiflora (A. Rich.) Kunth). Ainda é observado que a maioria das espécies dos gêneros Schinus e Lithrea apresenta um padrão de distribuição subtropical a temperado, ocorrendo no Uruguai, na Argentina e sul do Brasil até o Estado de São Paulo, onde tem seu limite norte de distribuição. Este padrão também é observado em outras famílias como, por exemplo, Apiaceae (Conium maculatum L., Eryngium eriophorum Cham. \& Schltdl e E. stenophyllum Urb.), Burseraceae (Protium kleinii Cuatrec), Myrsinaceae (Rapanea balansae Mez), Oxalidaceae (Oxalis conorrhiza (Feuillée) Jacq. e O. niederlienii Knuth) e Turneraceae (Piriqueta taubatensis (Urb.) Arbo) (Wanderley et al. 2006).

Em relação à distribuição das espécies de Anacardiaceae no Brasil, as regiões apresentam um número semelhante de táxons, sendo a região norte, com 26 spp., a que possui maior número de espécies, sendo Anacardium microsepalum Loes a espécie endêmica dessa região. Na região Nordeste, ocorrem 23 spp., sendo Apterokarpos gardneri Rizzini a espécie endêmica dessa região. No Sudeste, ocorrem 22 spp., e a espécie endêmica dessa região é Astronium glaziovii. No Centro-oeste, ocorrem 21 spp., sendo Anacardium corymbosum Barb. Rodr. a espécie endêmica dessa região. Na região Sul, ocorrem 17 spp., sendo Schinus spinosus Engl. endêmica dessa região (figura 11). Mais oito espécies endêmicas são registradas para o Brasil, porém com ocorrência em mais de uma região brasileira, é o caso de Anacardium parvifolium Ducke que ocorre no norte e nordeste; Astronium concinnum Schott, Spondias macrocarpa Engl., Spondias venulosa (Engl.) Engl. e Spondias tuberosa Arruda que ocorrem no nordeste e sudeste; Anacardium nanum A. St.Hil. e Astronium nelson-rosae Santin que ocorrem no centro-oeste e sudeste, e por fim, Cyrtocarpa caatingae J.D. Mitch. \& Daly que ocorre no nordeste, centro-oeste e sudeste (figura 11).

Nas regiões Norte e Sul do Brasil, o padrão de distribuição difere das demais regiões em relação ao número de espécies regionais, sendo que Anacardium e Thyrsodium, gêneros predominantemente amazônicos, são os responsáveis pelo número relativamente elevado de espécies regionais no norte, enquanto Schinus, 
gênero de distribuição austral, é o principal representante pelo número de espécies regionais no sul. Recentes discussões têm destacado o papel potencial da conservação do nicho (ou bioma) filogenético na formação de pools de espécies regionais (Donoghue 2008, Crisp et al. 2009). De acordo com Crisp et al. (2009), a conservação do bioma filogenético tem prevalecido nas regiões temperadas dos continentes e biomas do hemisfério sul durante a radiação das linhagens de plantas, tanto dentro dos continentes como em colonizações transoceânicas. Além disso, o sucesso evolutivo desses táxons seria resultado da expansão desses biomas devido a mudanças climáticas e não por adaptação a novos biomas (evolução de nicho). Já para a região tropical, Wiens \& Donoghue (2004) sugerem a hipótese de conservação de nicho tropical, onde as linhagens teriam originado e diversificado nesta região devido à estabilidade climática a longo prazo e também pela tendência das espécies reterem o nicho climático ao longo da escala evolutiva.

No centro-oeste, nordeste e sudeste, com exceção das espécies endêmicas de cada região, não existem espécies regionais. Isto se deve ao fato de que as divisões políticas em regiões não necessariamente correspondem à classificação em setores biogeográficos como, por exemplo as regiões fitogeográficas de Takhtajan (1986) ou reinos biogeográficos de Morrone (2002), bem como as categorias inferiores propostas por cada sistema (regiões, sub-regiões, províncias e setores), que são o fundamento empírico primário da biogeografia. As espécies que compõem essas regiões são amplamente distribuídas nos domínios do cerrado e da Mata Atlântica e menos frequente na caatinga, por isso não se observa espécies regionais uma vez que esses domínios ocorrem nas três regiões. 
Figura 8: Distribuição de Anacardium humile (•) e Anacardium occidentale ( $\mathbf{\Delta}$ ) no Estado de São Paulo.

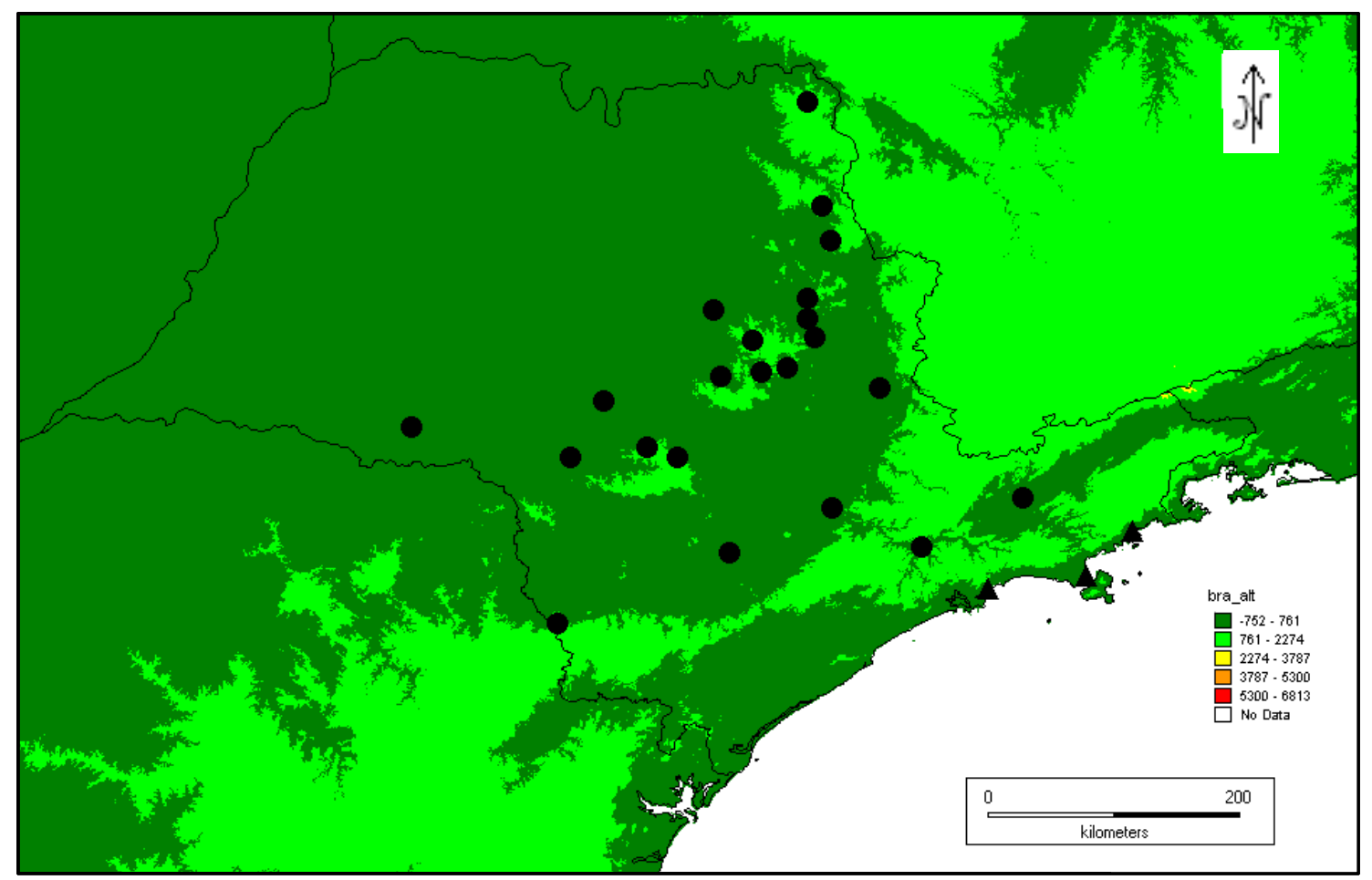

Figura 9: Distribuição de Tapirira guianensis $(\bullet)$ e Tapirira obtusa $(\boldsymbol{\Lambda})$ no Estado de São Paulo.

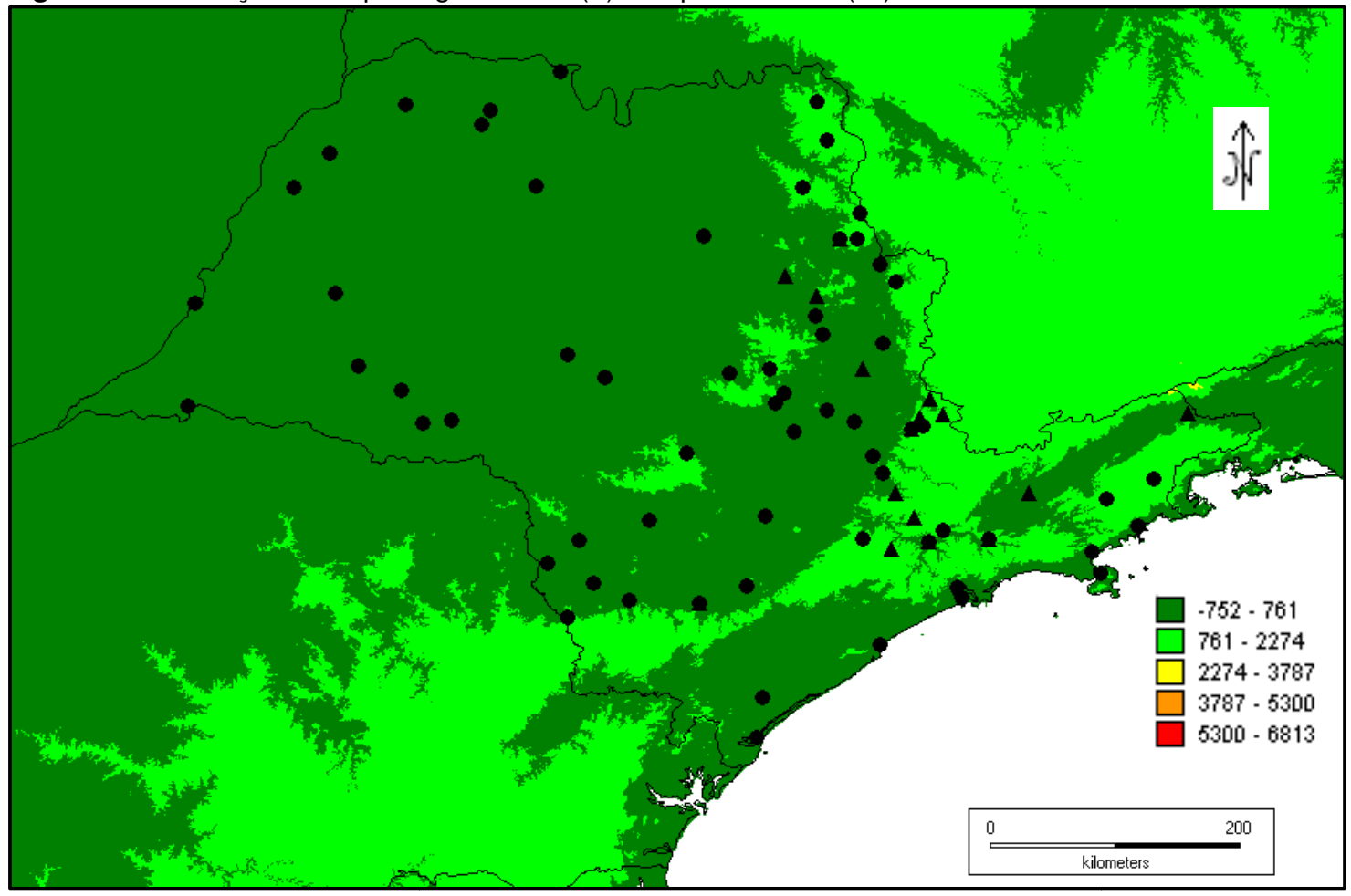



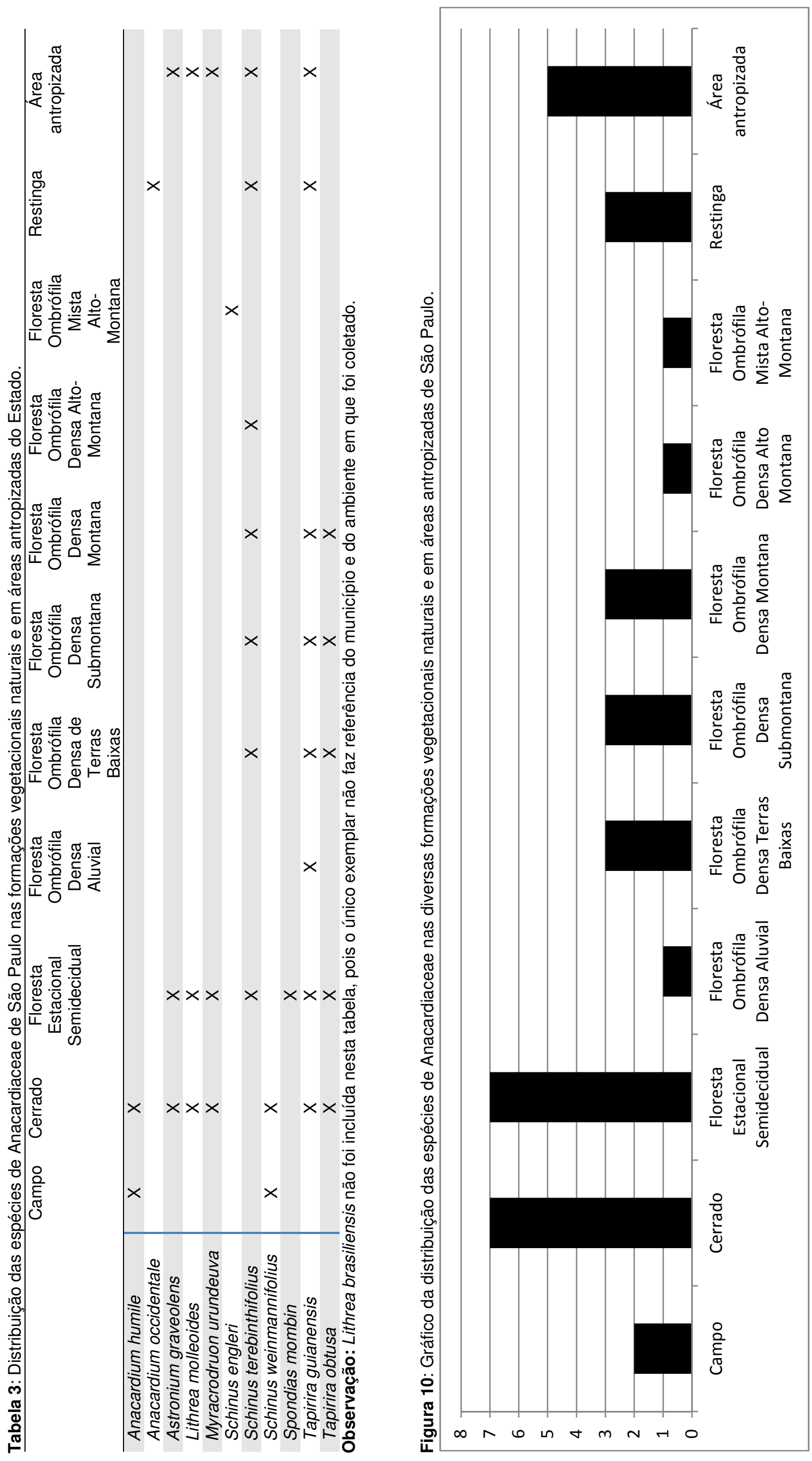
Figura 11: Número de espécies de Anacardiaceae por região brasileira. As áreas brancas em cada diagrama circular refere-se ao número de espécies regionais (não endêmicas do Brasil); as áreas cinza-claras expressam o número de espécies endêmicas da região e as áreas cinza-escuras expressam o número de espécies que também ocorrem em outras regiões brasileiras. Os círculos pretos indicam o número de espécies endêmicas compartilhadas pelas duas regiões conectadas por pontilhados brancos. As setas pretas ilustram os gêneros que possuem riqueza de espécies na região. Dados baseados em Silva-Luz \& Pirani 2010. Não foram considerados níveis infraespecíficos.

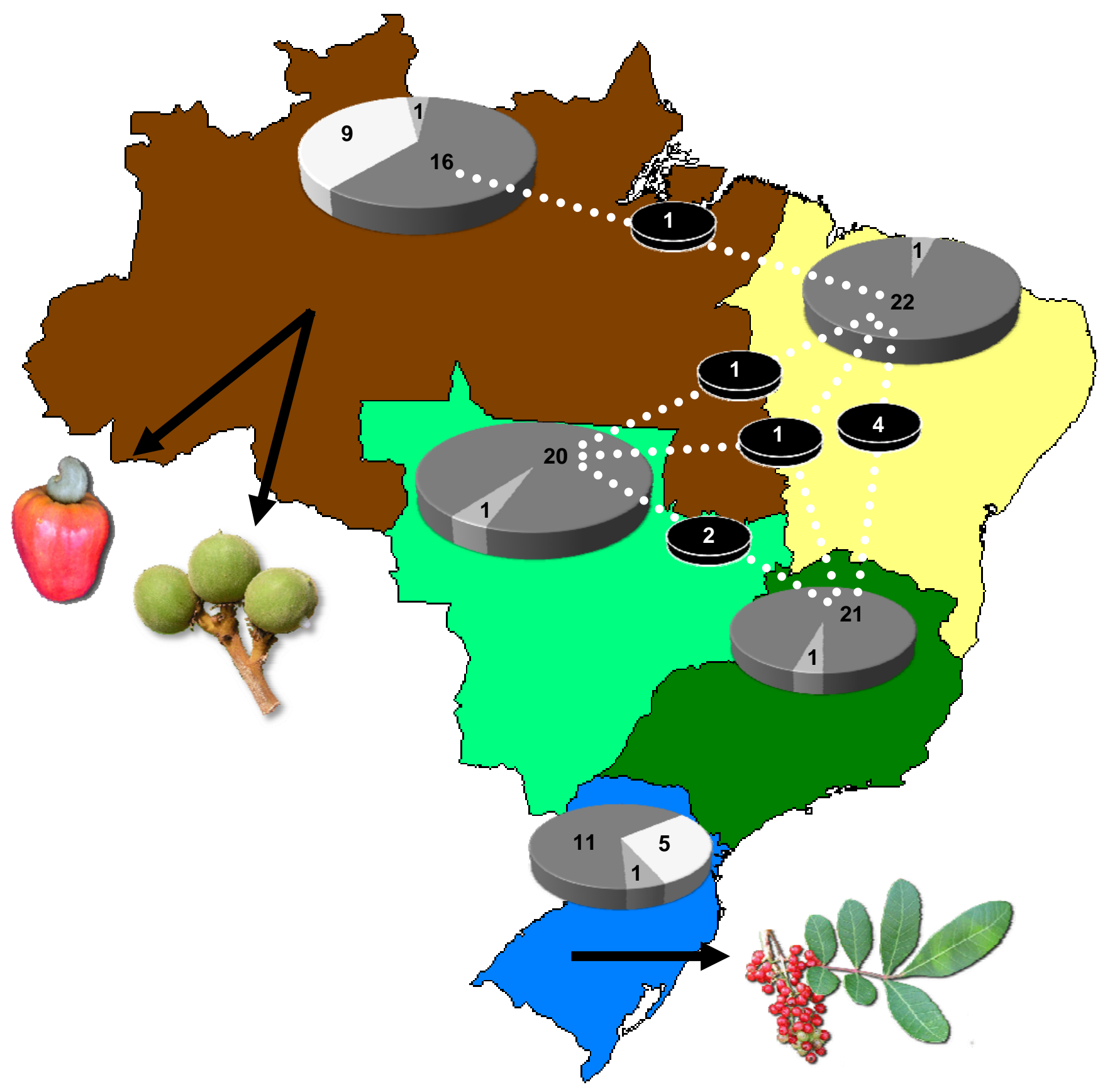




\subsection{Diversidade sexual e padrões fenológicos gerais das Anacardiaceae de São Paulo}

Desde os estudos de Charles Darwin é reconhecido que as angiospermas possuem uma diversidade de sistemas sexuais incomparável. Determinar os fatores genéticos e ecológicos que guiam a diversificação sexual atual é um tema central na biologia evolutiva das plantas. A integração dos estudos filogenéticos, ecológicos e de genética de populações tem proporcionado uma nova compreensão dos mecanismos seletivos que são responsáveis pelas principais transições entre os modos reprodutivos. É importante ressaltar que as angiospermas apresentam uma notável labilidade ecológica e evolutiva no sistema sexual (Barrett 2002).

Bawa \& Beach (1981) sugerem que os sistemas sexuais, tais como os observados em plantas hermafroditas, monóicas, andromonóicas, ginomonóicas, dióicas, androdióicas e ginodióicas são padrões relativos à alocação de recursos às funções paternais e maternais para melhorar o sucesso reprodutivo maternal e paternal de diferentes formas. Ressaltam ainda que esses padrões diferentes surgem principalmente em resposta à competição reprodutiva, resultado da seleção sexual e, por fim, que a evolução de um padrão particular é formada devido à dinâmica do sistema de polinização.

Flores de espécies dióicas são geralmente pequenas e pouco especializadas possuindo cores claras e inconspícuas (Bawa 1980). Tal padrão é observado na maioria dos gêneros da família Anacardiaceae, a qual apresenta táxons com flores unissexuais que frequentemente portam pistilo ou estames rudimentares (pistilódio e estaminódios) em plantas dióicas (Ibarra-Marínquez \& Oyama 1992, Renner \& Ricklefs 1995), sendo que poucas espécies são plantas hermafroditas ou poligamodióicas. Frequentemente o sexo das flores de muitos grupos tem sido confundido devido à ausência de estudos morfológicos acurados e pela carência no entendimento da necessidade de se adotar um critério mais funcional do que morfológico ao se interpretar a sexualidade nas plantas (Barrett 2002). Isto é observado principalmente nas flores classificadas como polígamas, quando na realidade trata-se de flores funcionalmente unissexuais. Em muitos casos as flores masculinas são claramente unissexuais (com o ovário pequeno abortivo), enquanto as flores femininas aparentam ser bissexuais, mas os estames possuem anteras abortivas, estado que é evidenciado somente quando estas são seccionadas (Wannan 2006).

Apesar de apenas cerca de $6 \%$ das angiospermas possuírem flores unissexuais (Renner \& Ricklefs 1995), a dioicia é o sistema sexual predominante nas Anacardiaceae, inclusive nos táxons que ocorrem no Estado de São Paulo. Acreditase que esse sistema sexual provavelmente surgiu várias vezes ao longo da história 
evolutiva das angiospermas, sendo a redução de endogamia e a seleção sexual os principais fatores responsáveis pela evolução desse sistema reprodutivo (Bawa 1980).

Em relação às espécies de Anacardiaceae do Estado de São Paulo, Astronium graveolens, Lithrea brasiliensis, L. molleoides, Myracrodruon urundeuva, Schinus engleri, S. terebinthifolius, S. weinmannifolius, Tapirira guianensis e T. obtusa apresentam flores unissexuais em plantas dióicas. Anacardium humile e $A$. occidentale são espécies andromonóicas e Spondias mombin possui flores bissexuais em plantas hermafroditas.

Estudos com espécies dióicas em ecossistemas tropicais mostram forte associação entre a dioicia e a polinização por grande variedade de insetos generalistas (Bawa 1980). Estudos de biologia floral realizados em diversas regiões do Brasil (Lenzi \& Orth 2004, Lenza \& Oliveira 2005, Cesário \& Gaglianone 2008, Villa et al. 2010) têm mostrado que as flores de Schinus terebinthifolius e Tapirira guianensis são visitadas por abelhas, moscas e vespas, sendo classificadas como generalistas quanto à diversidade da entomofauna visitante floral.

Lenzi \& Orth (2004) chamam a atenção para a presença de dimorfismo sexual, manifestado na maioria das espécies de Anacardiaceae do Estado de São Paulo pelo maior comprimento e largura das inflorescências masculinas, fato já mencionado por Fleig (1989) para Schinus terebinthifolius e para Lithrea e Tapirira por Pirani (1982). Acredita-se que a divisão de funções poderia ocasionar diferenças nas dimensões das inflorescências masculinas e femininas (características sexuais secundárias). Em plantas dióicas, esse caráter geralmente está associado também com o maior tamanho dos indivíduos masculinos e, consequentemente, com maior número de inflorescências e flores masculinas produzidas (e.g. Lloyd \& Webb 1977, Bawa 1980), as quais produzem maior suprimento de pólen, elevando a probabilidade de deixar um número maior de descendentes (Obeso \& Retuerto 2001). Essas diferenças são consideradas estratégias adaptativas que levam ao aumento das chances dos grãos de pólen chegarem aos estigmas, mesmo se houver grandes perdas (Carmo \& Franceschinelli 2002). No entanto, a semelhança entre as flores de S. terebinthifolius somada à sincronia da fenofase reprodutiva, da antese e da oferta dos recursos tróficos parece diminuir as diferenças, favorecendo o sucesso reprodutivo por meio da atração dos visitantes florais às flores masculinas e femininas (Lenzi \& Orth 2004). Quanto ao período de floração e frutificação, estudos realizados em restingas (Lenzi \& Orth 2004, Cesário \& Gaglianone 2008) indicam que $S$. terebinthifolius apresenta dois períodos de floração, de outubro a novembro e de fevereiro a abril. A análise dos exemplares herborizados do Estado de São Paulo mostrou coletas dessa espécie com flores de junho a abril e coletas com frutos de 
janeiro a julho e de setembro a novembro (tabela 5), sendo tais dados semelhantes aos encontrados no estudo das Anacardiáceas de Santa Catarina (Fleig 1989). Estudos taxonômicos (Mitchell 1997, Pennington et al. 2004a), anatômicos (Wannan \& Quinn 1991, Bachelier \& Endress 2009) e de fenologia (Lenzi \& Orth 2004, Cesário \& Gaglianone 2008, Villa et al. 2010), caracterizaram os táxons do gênero Schinus como plantas dióicas, porém também é citado na literatura, inclusive na revisão do gênero (Barkley 1957), que as espécies são poligamodióicas. Indivíduos poligamodióicos foram observados no estudo de biologia floral de Schinus terebinthifolius realizado por Cesário \& Gaglianone (2008), o qual evidenciou que alguns indivíduos na população (aproximadamente $2 \%$ ), embora apresentassem flores masculinas, portavam alguns frutos bem formados, concluindo que a ocorrência de indivíduos poligamodióicos em populações desta espécie, parece ser um fenômeno pouco frequente.

Estratégias reprodutivas similares às encontradas em Schinus terebinthifolius foram observadas em um estudo de biologia floral de Tapirira guianensis (Lenza \& Oliveira 2005). Entre as estratégias, é possível citar a sincronia da floração entre os indivíduos, contribuindo para os altos valores de intensidade de floração na população e o comprimento médio das inflorescências masculinas é significantemente maior que o das inflorescências femininas. Em espécies dióicas, como é o caso de $T$. guianensis, a sincronia da floração entre indivíduos dos dois sexos pode também ter papel importante no que diz respeito à polinização, pois como os picos de floração são breves, o fluxo de pólen entre os indivíduos poderia ser comprometido caso houvesse uma grande separação temporal na apresentação das flores pelos dois sexos (Lenza \& Oliveira 2005). Outra estratégia observada em T. guianensis é que enquanto as plantas masculinas investem em maior "display" floral, possivelmente incrementando a atração de visitantes florais e a exportação de pólen, as plantas femininas possuem maior longevidade floral, que também pode ter papel similar, aumentando as chances de polinização e produção de frutos (Primack 1985). Tapirira guianensis é geralmente caracterizada como funcionalmente dióica, porém também é citado na literatura que a espécie é poligamodióica (Engler 1876, Blackwell \& Dodson 1968). De acordo com Lenza \& Oliveira (2005), ocasionalmente, foram observadas algumas flores bissexuais em dois indivíduos femininos da população, que forneciam pólen e néctar. O gineceu destas flores possuía um óvulo, como nas flores femininas, no entanto, o ovário era menos desenvolvido; enquanto o androceu era similar ao das flores masculinas, mas com as anteras um pouco menores. Foi observada a liberação de grãos de pólen bem desenvolvidos, entretanto a viabilidade desses não foi testada. É importante mencionar que a análise de grande quantidade de flores produzidas por vários indivíduos de T. guianensis da Serra do Cipó ao longo de dois anos (Pirani 1987) 
indicou sempre a presença de flores funcionalmente masculinas com pistilódio reduzido e alta porcentagem de grãos de pólen viáveis, e flores funcionalmente femininas que, sem exame acurado, parecem bissexuais, pois o androceu é bem desenvolvido, mas as anteras são estéreis, desprovidas de pólen. A manutenção de órgãos rudimentares do sexo oposto nas flores masculinas e femininas de plantas dióicas mostra que a separação dos sexos deva ser um fenômeno relativamente recente (Rottenberg 1998). Adicionalmente, a presença ocasional de flores bissexuais em indivíduos femininos indica que a separação dos sexos em $T$. guianensis é ainda incompleta, mostrando sinais de um suposto ancestral hermafrodita (Lenza \& Oliveira 2005). Especula-se ainda que a manutenção de estaminódios numa flor funcionalmente feminina seja seletivamente vantajosa por ter um efeito mimético: flores desprovidas de pólen, mas "simulando" flores masculinas continuariam sendo visitadas pelos polinizadores, ao passo que flores que perdessem totalmente os estames logo seriam reconhecidas e evitadas pelos visitantes. Esse fenômeno foi denominado dioicia críptica por Schmid (1978) ou tratado como caso de mimetismo batesiano reprodutivo (Schaefer \& Ruxton 2010), onde a flor-modelo oferece recurso enquanto a flor-mimética que a "imita" se beneficia da visita de polinizadores que a confudem com a flor-modelo. Também autores como Kawagoe \& Suzuki (2004) afirmam que estaminódios em flores pistiladas devem ter papel importante na atração de polinizadores. Uma revisão crítica desse tema foi recentemente realizada por Schaefer \& Ruxton (2010).

Em relação ao período de floração e frutificação de Tapirira guianensis, dois picos de floração anuais bem marcados são citados na literatura (Warming 1908, Pirani 1987) para populações da porção centro-sul de Minas Gerais: um de março a maio e outro de setembro a dezembro, este muito mais expressivo, seguidos de duas frutificações, uma em maio e junho e outra de novembro a março. No presente trabalho, contudo, no material examinado do Estado de São Paulo existem coletas de material florífero em praticamente todos os meses do ano (de junho a abril), como observado também em Schinus terebinthifolius. Quanto ao período de frutificação, foram coletados em São Paulo indivíduos dessas duas espécies com frutos em todos os meses do ano exceto abril (tabela 5). Isso pode ser devido a não-ocorrência de duas floradas nos indivíduos paulistas de Tapirira e de Schinus, ou a ocorrência dos dois períodos no nível individual, porém mascarados por ampla variação de extensão das floradas ao longo das populações da espécie no Estado. Essa segunda hipótese é favorecida pelo fato de que os estudos de Warming (1908) e de Pirani (1987) com Tapirira guianensis terem sido baseados em observações mensais feitas em populações locais de Lagoa Santa e Serra do Cipó. Uma vez que as indicações aqui 
sugeridas com base no material de São Paulo constituem uma somatória de coletas de todo o Estado, deve-se esperar variação nos períodos das floradas em diferentes áreas do Estado.

Em contraste com as espécies de Anacardiaceae anteriormente tratadas, de acordo com Santin (1989), Astronium graveolens não apresenta sincronismo entre indivíduos na fase de reprodução. Essa espécie apresenta uma fase que precede a floração, na qual as folhas ficam amareladas, em seguida avermelhadas e depois caem (Santin 1989). No Brasil, assim como no Estado de São Paulo, a floração ocorre geralmente entre os meses de agosto e dezembro.

O padrão decíduo se observa também em Myracrodruon urundeuva, árvores que iniciam a derrubada foliar nos meses de junho e julho, com subsequente floração que ocorre entre os meses de julho e setembro. O período de frutificação ocorre entre agosto e outubro, quando as folhas jovens estão se desenvolvendo (Santin 1989). No Estado de São Paulo observa-se que os períodos de floração e frutificação ocorrem geralmente entre os meses de junho e outubro (tabela 5). Estudos realizados em outras áreas do Brasil (Barbosa et al. 1989, Machado et al. 1997) indicam que, de modo geral, a produção de flores dessa espécie está relacionada com a estação seca.

Em síntese, as espécies dióicas da família Anacardiaceae que ocorrem no Estado de São Paulo apresentam morfologia floral semelhante, por isso é provável que possuam estratégias reprodutivas similares às acima descritas. Uma exceção notável ao padrão de dimorfismo sexual de inflorescências é Schinus engleri, com seus pseudorracemos axilares curtos.

Barrett (2002) sugere que a taxa de especiação seja mais reduzida nos clados dos táxons dióicos e responsável pela baixa riqueza de espécies dessas linhagens, pois a dioicia é comumente associada aos sistemas de polinização não especializados, os quais envolvem fatores abióticos, água e ar, e fatores bióticos como polinizadores generalistas, mais do que polinizadores especialistas, que geralmente conduzem a diversificação floral e isolamento reprodutivo em muitos grupos de angiospermas com flores bissexuais.

Quanto às Anacardiaceae não-dióicas, no Estado de São Paulo ocorrem espécies andromonóicas (Anacardium) e hermafroditas (Spondias) (tabela 4). Comumente, plantas produzem muito mais flores do que frutos que chegam à maturidade, sendo que se supõe que as flores que não resultam em frutos possam servir para atrair polinizadores e/ou dispersar pólen (Bawa \& Beach 1981). A andromonoicia pode simplesmente estar representando a situação em que pistilos não funcionais são abortados antes da floração nas flores que estão destinadas a servir com função masculina ou de atração (Zapata \& Arroyo 1978). No entanto, é notável 
que a andromonoicia, embora amplamente distribuída em várias famílias, seja relativamente rara quando comparada ao hermafroditismo (Bawa \& Beach 1981).

É citado na literatura que Anacardium humile apresenta baixa capacidade de produção de frutos e sementes. Segundo Almeida et al. (1998 apud Carvalho et al. 2005), tal fato ocorre devido à alta proporção entre flores masculinas e bissexuais (4:1), sendo que apenas um, em cada oito ou dez estames, é fértil. Em relação ao pólen, Mitchell \& Mori (1987) afirmam que em A. humile e A. occidentale as anteras menores produzem pólen aparentemente idêntico ao que é produzido nas anteras maiores. No entanto, o estudo de ontogenia do cajueiro anão precoce (Oliveira \& Mariath 2001) mostrou que um número menor de grãos de pólen é produzido por antera menor em relação a antera maior. A baixa proporção entre flores masculinas e bissexuais também é observada em Anacardium occidentale, sendo que o estudo de biologia floral realizado por Barros et al. (2002) demonstrou que no cajueiro anão precoce existem cerca de 201,9 flores por inflorescência, das quais apenas 3,9\% são bissexuais, enquanto no cajueiro comum, das 173,8 flores por inflorescência, 7,9\% são bissexuais. No que se refere aos visitantes florais das espécies de Anacardium, são observadas borboletas e abelhas. O período de floração das espécies de Anacardium ocorre no início da estação seca (Mitchell \& Mori 1987). Tal padrão também foi observado nos exemplares de A. humile e A. occidentale do Estado de São Paulo.

No caso de Spondias mombin, os dados indicam floração no estado de São Paulo nos meses de outubro e novembro. Porém, o estudo de biologia floral da espécie feito por Ramos (2009) no Pará, aponta amplo período de floração entre os meses de julho e janeiro, correspondente à estação seca naquela região, com pico de floração entre os meses de agosto e setembro. Nesse estudo, S. mombin foi caracterizada como andromonóica, no entanto Mitchell \& Daly (1998) acreditam que, com exceção de $S$. purpurea L., as flores das espécies neotropicais são estruturalmente e funcionalmente bissexuais. A análise dos espécimes do Estado de São Paulo também mostrou somente flores bissexuais, e por isso $S$. mombin é aqui caracterizada como planta hermafrodita (tabela 4). No que se refere às estratégias para evitar a autopolinização, Mitchell \& Daly (1998) afirmam que as flores dessa espécie são fortemente protândricas, pois no momento em que o pólen é disperso, 0 ovário não está desenvolvido e o pistilo é aparentemente representado somente por quatro ou cinco estiletes conatos na base. Quando o ovário está aparentemente desenvolvido, as anteras estão quase vazias e senescentes. Porém Ramos (2009) demonstrou por meio do teste de receptividade do estigma que este se encontra receptivo cerca de uma hora após a antese, e que a deiscência das anteras ocorre juntamente com a abertura das flores, o que aparentemente constituiria um caso muito 
sutil de protandria. Comumente é sugerido que o amadurecimento em tempos distintos das partes masculina e feminina de uma flor (dicogamia) reduziria a probabilidade de autopolinização (e.g. Barrett 2002).

Dentre os visitantes florais de Spondias, o estudo de Ramos (2009) demostrou que se pode considerar as abelhas os polinizadores potenciais, pois embora uma variedade de insetos generalistas tenha visitado as flores de $S$. mombin nas populações analisadas, apenas as abelhas apresentaram comportamento típico de polinizadores, por contatarem os órgãos reprodutivos das flores. Adicionalmente, a análise do pólen carregado pelas abelhas mais frequentes corrobora com o fato destas serem os principais polinizadores já que foi encontrado apenas pólen de $S$. mombin.

Finalmente, os dados compilados na Tabela 5 permitem apreciar que a floração das espécies de Anacardiaceae do Estado de São Paulo, de modo geral, ocorre na transição da estação seca e chuvosa, entre os meses de julho e dezembro , porém os dados de herbários estudados indicam que podem ser encontrados indivíduos de Lithrea molleoides, Schinus terebinthifolius e Tapirira guianensis com flores ou frutos praticamente em todos os meses do ano. 
Tabela 4: Sistemas sexuais em Anacardiaceae. Dados provenientes do estudo das Anacardiaceae do Estado de São Paulo (ם) e dados provenientes da literatura $(\bullet)$.

\begin{tabular}{|c|c|c|c|c|c|}
\hline & Dióico & Poligamodióico & Hermafrodita & Andromonóico & Monóico \\
\hline Anacardium humile & & & & $\square$ & \\
\hline $\begin{array}{l}\text { Anacardium } \\
\text { occidentale }\end{array}$ & & & & $\mathbf{\square}$ & \\
\hline Astronium graveolens & $\mathbf{\square}$ & $\bullet$ & & & \\
\hline Lithrea brasiliensis & $\square$ & $\bullet$ & & & \\
\hline Lithrea molleoides & $\square$ & $\bullet$ & & & \\
\hline $\begin{array}{c}\text { Myracrodruon } \\
\text { urundeuva }\end{array}$ & $\mathbf{\square}$ & & & & \\
\hline Schinus engleri & $\mathbf{\square}$ & $\bullet$ & & & \\
\hline Schinus terebinthifolius & $\mathbf{\square}$ & $\bullet$ & & & \\
\hline $\begin{array}{c}\text { Schinus } \\
\text { weinmannifolius }\end{array}$ & $\mathbf{\square}$ & $\bullet$ & & & \\
\hline Spondias mombin & $\bullet$ & $\bullet$ & $\mathbf{\square}$ & $\bullet$ & $\bullet$ \\
\hline Tapirira guianensis & $\mathbf{\square}$ & $\bullet$ & & & $\bullet$ \\
\hline Tapirira obtusa & $\mathbf{\square}$ & $\bullet$ & & & $\bullet$ \\
\hline
\end{tabular}

Tabela 5: Registros de floração (๘) e de frutificação $(\bullet)$ das espécies de Anacardiaceae do Estado de São Paulo baseados nas coleções de herbário analisadas.

\begin{tabular}{|c|c|c|c|c|c|c|c|c|c|c|c|c|}
\hline & Jan & Fev & Mar & Abr & Mai & Jun & Jul & Ago & Set & Out & Nov & Dez \\
\hline $\begin{array}{c}\text { Anacardium } \\
\text { humile }\end{array}$ & & & & & & & & - & ! & ! & $\bullet$ & - \\
\hline $\begin{array}{l}\text { Anacardium } \\
\text { occidentale }^{*}\end{array}$ & & - & & & & & & & - & घ & - & - \\
\hline $\begin{array}{l}\text { Astronium } \\
\text { graveolens }\end{array}$ & & & & & & & & घ & $\bullet$ & & & - \\
\hline $\begin{array}{l}\text { Lithrea } \\
\text { molleoides }\end{array}$ & $\bullet$ & $\bullet$ & $\bullet$ & $\bullet$ & $\bullet$ & $\bullet$ & - & - & $\bullet$ & - & ! & $\bullet$ \\
\hline $\begin{array}{c}\text { Myracrodruon } \\
\text { urundeuva }\end{array}$ & $\bullet$ & & & - & & - & - & - & $\bullet$ & - & & \\
\hline $\begin{array}{l}\text { Schinus } \\
\text { engleri }\end{array}$ & & & & & & & - & - & - & $\bullet$ & $\bullet$ & $\bullet$ \\
\hline $\begin{array}{l}\text { Schinus } \\
\text { terebinthifolius }\end{array}$ & - & - & - & - & $\bullet$ & - & - & - & - & - & - & - \\
\hline $\begin{array}{c}\text { Schinus } \\
\text { weinmannifolius }\end{array}$ & • & & & & & & & & & & $\bullet$ & $\bullet$ \\
\hline $\begin{array}{l}\text { Spondias } \\
\text { mombin* }\end{array}$ & & & & & & & & & & - & घ & \\
\hline $\begin{array}{c}\text { Tapirira } \\
\text { guianensis }\end{array}$ & - & - & - & - & • & - & - & - & - & - & - & $\bullet$ \\
\hline $\begin{array}{l}\text { Tapirira } \\
\text { obtusa }\end{array}$ & - & - & • & & & & & - & $\bullet$ & $\bullet$ & $\bullet$ & \\
\hline
\end{tabular}




\section{Considerações finais}

Como o resultado de um esforço em conjunto de mais de 200 pesquisadores de universidades e institutos de pesquisas nacionais e internacionais, o projeto "Flora Fanerogâmica do Estado de São Paulo", iniciado em 1993, está no sexto volume publicado. Das 7.500 espécies de fanerógamas estimadas para o Estado de São Paulo, até o momento foram descritas 2.767 espécies em 655 gêneros, perfazendo $37 \%$ do total (Wanderley et al. 2009). Nesse contexto, a presente dissertação de mestrado teve como principal objetivo ampliar os estudos da flora fanerogâmica do Estado de São Paulo e o conhecimento da diversidade das espécies da família Anacardiaceae na área de estudo, assim como no Brasil, uma vez que a maioria dos táxons estudados apresenta ampla distribuição no país. Adicionalmente, visou-se a avaliar o grau de conservação das espécies de Anacardiaceae do Estado de São Paulo.

Desde agosto de 2011, encontra-se disponível a versão online da "Lista de espécies da flora do Brasil", que é dinâmica e toda informação validada pelos especialistas torna-se imediata e amplamente acessível. Dessa maneira, os dados do presente estudo auxiliarão na atualização das espécies de Anacardiaceae no Catálogo de Plantas e Fungos do Brasil, pois foram observadas algumas lacunas principalmente no que se refere à distribuição geográfica dos táxons de Anacardiaceae ora estudada. Entre as lacunas observadas é possível citar a ausência de Spondias mombin no Estado de São Paulo, agora registrada, e a necessidade de retificação do limite de distribuição de algumas espécies, tais como Schinus weinmannifolius, que tem o limite norte no Estado de São Paulo, e Schinus molle, com limite norte no Paraná.

No que se refere à biologia floral e à diversidade sexual exibida pelas Anacardiaceae, os principais sistemas e padrões presentes nas espécies ocorrentes em São Paulo foram brevemente abordados no presente trabalho. Porém estudos acurados de ontogenia, anatomia e de biologia reprodutiva são essenciais para auxiliar no entendimento da morfologia e funcionalidade dos sexos das flores dessa família, uma vez que um olhar com foco apenas na morfologia pode levar a interpretações superficiais ou errôneas. Ademais, de posse de dados morfológicos acurados juntamente com dados moleculares, hipóteses sobre a evolução dos sistemas sexuais em Anacardiaceae podem ser levantadas e ainda confrontadas com as hipóteses correntes, tais como as ideias sobre as estratégias de polinização e dispersão observadas em plantas lenhosas de florestas tropicais.

Em relação às dificuldades encontradas durante a realização deste estudo surgiram algumas questões relacionadas a problemas nomenclaturais, tais como qual 
determinação do gênero gramatical do nome Schinus L. e conseqüente problemática de emprego dos epítetos terebinthifolius ou terebinthifolia, ambos correntemente encontrados na literatura. A etimologia do gênero Lithrea Miers ex Hook. \& Arn. (ou Lithraea) e a autoria da família Anacardiaceae (Robert Brown ou Lindley) foram outras questões enfrentadas, com apoio da bibliografia específica da família e no Código Internacional de Botânica, bem como de discussões levantadas junto a especialistas em nomenclatura.

No que concerne à taxonomia, as revisões disponíveis de táxons neotropicais de Anacardiaceae trouxeram grandes contribuições para o entendimento da biologia e taxonomia das espécies de Anacardiaceae e facilitaram etapas fundamentais do presente trabalho. É o caso da monografia de Anacardium (Mitchell \& Mori 1987), gênero com plantas de folhas simples, com flores unissexuais e bissexuais no mesmo indivíduo (sistema andromonóico) e pedicelo do fruto dilatado e carnoso formando um hipocarpo. Nessa revisão, é apresentado um grande conjunto de dados sobre a biologia, ecologia e taxonomia do grupo. As hipóteses filogenéticas geradas pela análise de caracteres morfológicos nesse gênero não se mostraram totalmente resolvidas no clado que compreende as espécies Anacardium humile, A. nanum A. St.Hil., A. corymbosum Barb. Rodr., Anacardium occidentale e A. spruceanum Benth. ex Engl. Além disso, as relações entre os táxons $A$. giganteum Hancock ex Engl., $A$. fruticosum Mitch. \& Mori, A. microsepalum Loesener e A. parvifolium Ducke aparecem em uma grande politomia. Dessa forma, é fortemente preconizado um estudo de cunho filogenético agregando dados moleculares e morfológicos, com vistas a evidenciar um quadro mais consistente das relações entre as espécies e, consequentemente, elucidar padrões evolutivos e biogeográficos entre esses táxons com hábitos e habitats tão variáveis como árvores amazônicas de grande porte e arbustos geoxílicos do cerrados e campos.

Ainda é bastante polêmica a taxonomia dos gêneros Astronium e Myracrodruon, apesar destes apresentarem uma delimitação relativamente consistente entre quase todas as espécies. Os dois gêneros possuem folhas compostas imparipinadas, flores unissexuais em plantas dióicas e frutos característicos devido ao cálice ampliado. O trabalho de taxonomia mais recente desse grupo é a revisão do gênero Astronium (Santin 1989), que provê a contextualização da problemática taxonômica e faz o restabelecimento de Myracrodruon com base em caracteres reprodutivos. No entanto, a manutenção de Myracrodruon como subgênero de Astronium como proposto por Barkley (1968) também parece ser justificada, pois ambos estudos filogenéticos recentes mostram que eles emergem como cladosirmãos (Pell comum. pess.). Além disso, Myracrodruon é um gênero composto por 
apenas dois táxons com morfologia similar às espécies de Astronium, e levando em consideração que existe uma tendência atual de se buscar produzir classificação maximizando informações a partir de filogenias, talvez fosse mais interessante e informativo que essas espécies compreendessem um mesmo gênero com dois grupos infragenéticos (subgêneros ou seções). A realização futura de estudos filogenéticos com um número maior de espécies amostradas deverá prover uma filogenia robusta e com base nesses dados será possível buscar uma melhor compreensão da evolução dos caracteres morfológicos e dos padrões biogeográficos nesse grupo.

As espécies de Schinus e Lithrea são características da vegetação da região sul da América do Sul. São táxons que apresentam folhas compostas imparipinadas, ou, no caso de algumas espécies de Schinus, folhas simples com ramo terminado em espinho. Em ambos gêneros as flores são geralmente unissexuais em plantas dióicas e o fruto tem epicarpo vermelho, verde-claro ou verde-cinéreo que se desprende do mesocarpo quando maduro. Os táxons de Lithrea possuem uma delimitação relativamente bem estabelecida desde a revisão feita por Barkley (1962), e são prontamente distintos das espécies de Schinus por apresentar frutos esverdeados e ainda pela nervura marginal cartilaginosa conspícua.

A delimitação entre as espécies de Schinus de folhas simples ainda é complicada devido à ampla variação morfológica das estruturas vegetativas que esses táxons possuem, sendo que essa variação pode ser influenciada pelo estádio de desenvolvimento da planta. Só no Estado de São Paulo, para uma mesma espécie de Schinus de folhas simples, pelo menos quatro nomes eram empregados: $S$. ramboi, $S$. engleri, S. longifolius (Lindl.) Speg. e S. polygamus (Cav.) Cabrera. Com base no estudo dos protólogos e na análise dos materiais-tipo, verificou-se que $S$. longifolius e S. polygamus apresentam caracteres reprodutivos que claramente as distinguem das demais espécies, enquanto a distinção entre $S$. ramboi e $S$. engleri é mais complicada, porque exibem grande sobreposição de caracteres vegetativos e reprodutivos. Fica evidente que apesar de existir uma revisão taxonômica disponível sobre o gênero (Barkley 1957), ainda existem sérios problemas de delimitação entre as espécies que justificam novos estudos morfológicos e taxonômicos, de preferência com intensas análises a campo e uso de métodos modernos. Essa necessidade fica mais clara quando são consultadas as coleções de Schinus de folhas simples de diversos herbários do país, onde é notável a grande proliferação de nomes nessas coleções, muitas vezes errôneos. Dessa maneira, faz-se necessário uma nova revisão taxonômica agregando também o estudo de plântulas e de indivíduos juvenis, tendo em vista que a morfologia também é influenciada pelo estádio de desenvolvimento da planta. Além disso, realizar um estudo filogenético tendo como objetivo a 
compreensão das relações entre as espécies do gênero Schinus e com base nesses dados buscar os padrões biogeográficos das espécies. Ainda em relação aos estudos biogeográficos, mas com foco na biogeografia histórica, congregar os dados de Schinus com as informações de outros táxons que exibam padrões de distribuição semelhantes, e dessa forma levantar possíveis hipóteses acerca dos fatores responsáveis pela dinâmica dos campos da América do Sul, vegetação em que as espécies de Schinus apresentam grande diversidade de espécies.

Com base no exposto é possível perceber que a amplitude de lacunas de estudos sobre a família Anacardiaceae ainda é considerável, tendo em vista que no Brasil ocorrem 14 gêneros e aqui foram ressaltadas apenas algumas considerações sobre cinco deles. O momento atual é bastante propício para a implementação de estudos modernos como os preconizados acima, haja vista a gama de novas ferramentas, principalmente as moleculares, que podem ser utilizadas com o objetivo de contribuir para os estudos sistemáticos nos mais diversos níveis taxonômicos e ainda auxiliar a elucidar questões sobre a história evolutiva e padrões de distribuição geográfica das plantas. 


\section{Resumo}

O estudo da família Anacardiaceae tem o objetivo de contribuir com o plano mais amplo do levantamento da "Flora Fanerogâmica do Estado de São Paulo", que vem sendo subsidiado pela FAPESP desde 1994 e conta com a colaboração de pesquisadores de muitas universidades e institutos de pesquisa do Estado. As Anacardiaceae compreendem cerca de 81 gêneros e 800 espécies, presentes em ambientes secos a úmidos, principalmente em terras baixas nas regiões tropicais e subtropicais em todo o mundo, estendendo-se até as regiões temperadas. No Brasil a família encontra-se representada por 14 gêneros e 57 espécies. O levantamento das espécies foi realizado baseando-se nas coleções de Anacardiaceae do Estado de São Paulo depositadas nos herbários BHCB, BOTU, ESA, HRCB, MBM, IAC, PMSP, R, RB, SP, SPF, SPFR, SPSF e UEC, expedições de campo e consultas bibliográficas. Os resultados seguem o padrão da série "Flora Fanerogâmica do Estado de São Paulo". São apresentadas chaves de identificação para gênero e espécies, descrições morfológicas, ilustrações e dados sobre distribuição geográfica, habitat, variabilidade intraespecífica, período de floração e frutificação, grau de conservação das espécies e riscos de extinção. No Estado de São Paulo, há 12 espécies nativas distribuídas nos gêneros Anacardium, Astronium, Lithrea, Myracrodruon, Schinus, Spondias e Tapirira. Lithrea molleoides, Schinus terebinthifolius e Tapirira guianensis são as espécies mais amplamente distribuídas da família no Estado, sendo encontradas em quase todas as formações vegetacionais, inclusive em áreas antropizadas. Spondias mombin é encontrada na floresta Estacional Semidecidual e matas ciliares próximas ao rio Paraná, nas regiões noroeste e oeste do Estado. Schinus engleri é encontrada, no Estado de São Paulo, nas florestas Ombrófila Mista Alto-Montana de Campos do Jordão e da Serra da Bocaina e Schinus weinmannifolius ocorre nos cerrados e campos de Itararé e Itapeva, entre outros municípios localizados próximos à região sul-sudoeste do Estado de São Paulo. O gênero Anacardium é representado no Estado pelas espécies $A$. humile, planta com hábito geoxílico comum nos cerrados $\mathrm{e}$ A. occidentale, uma árvore pequena das restingas. Astronium graveolens e Myracrodruon urundeuva, assim como a maioria das espécies de Anacardiaceae, ocorrem nas Florestas Estacionais Semideciduais e nos cerrados do Estado de São Paulo. Um padrão de distribuição incomum é observado em Lithrea brasiliensis que, com exceção do material-tipo, não possui exemplares ulteriores do Estado de São Paulo depositados nos herbários consultados. Em relação ao grau de conservação das espécies, Lithrea brasiliensis deve ser categorizada como presumivelmente extinta (EX) e Myracrodruon urundeuva como quase ameaçada (NT), as demais espécies 
enquadram-se como espécies não ameaçadas, na categoria de preocupação menor (LC).

\begin{abstract}
The present study on Anacardiaceae aims to contribute with the broader survey project of the Phanerogamic flora of the São Paulo state which. This great efford has been supported by FAPESP since 1993 and counts on the collaboration of researchers from many universities and institutes of the state. The family comprises ca. 81 genera and 800 species distributed mostly in lowlands, from dry to moist habitats, throughout the tropics and subtropics worldwide and also extending into the temperate zone. lin Brazil Anacardiaceae is represented by 14 genera and 57 species. The present survey was carried out based on field work, bibliographical references on Anacardiaceae and examination of the collections from the following herbaria: $\mathrm{BHCB}$, BOTU, ESA, HRCB, MBM, IAC, PMSP, R, RB, SP, SPF, SPFR, SPSF, UEC. The results are presented following the Phanerogamic flora of Sao Paulo State. We provide identification keys to genera and species, morphological descriptions, illustrations and additional data on distribution, habitat, intraespecific variability, periods of flowering and fruiting, species conservation status. In the area this family is represented by 12 native species belonging Anacardium, Astronium, Lithrea, Myracrodruon, Schinus, Spondias e Tapirira. Lithrea molleoides, Schinus terebinthifolius and Tapirira guianensis are the most common and widespread Anacardiaceae species of São Paulo state and they are collected in almost all types of vegetation, including disturbed areas. Spondias mombin occurs in Sazonal Semidecidous and Riparian Forests next to the Paraná River in the northwest and the west regions of the state. S. engleri is reported for São Paulo state in the High-Montane Mixed Ombrophylous Forest of Campos do Jordão and Serra da Bocaina and S. weinmannifolius is found in the "cerrado" and "campos" of Itararé, Itapeva and other cities located next to the south and the south-west regions of the state. Anacardium is represented in the state by two species, A. humile, a "cerrado" common plant with geoxylic habit, and $A$. occidentale, a "restinga" small tree. Astronium graveolens and Myracrodruon urundeuva, as well as the majority of Anacardiaceae species are collected in Sazonal Semidecidous Forests and "cerrados" of São Paulo state. An uncommon distribution pattern is found in Lithrea brasiliensis, which is reported for São Paulo state only from type-material. In relation to the species conservation status, Lithrea brasiliensis should be categorized as Presumably Extinct (EX) and Myracrodruon urundeuva as Near Threatened (NT). The other species are classified as Least Concern (LC) category.
\end{abstract}




\section{Referências bibliográficas}

Almeida, S.P., Proença, C.E.B., Sano, S.M. \& Ribeiro, J.F. 1998. Cerrado: espécies vegetais úteis. Embrapa-Cpac, Planaltina.

Alves, A.S.A., Santos, L.L. \& Sales, M.F. 2009. Anacardiaceae. In Alves, M., Araújo, M.F., Maciel, J.R. \& Martins, S. (eds.) Flora de Mirandiba. Recife: Associação Plantas do Nordeste, p. 56-58.

Angiosperm Phylogeny Group APG II. 2003. An update of the Angiosperm Phylogeny Group classification for the orders and families of flowering plants: APG II. Botanical Journal of Linnean Society 141: 399-436.

Angiosperm Phylogeny Group APG III. 2009. An update of the Angiosperm Phylogeny Group classification for the orders and families of flowering plants: APG III. Botanical Journal of Linnean Society 161: 105-121.

Bachelier, J.B. \& Endress, P.K. 2009. Comparative floral morphology and anatomy of Anacardiaceae and Burseraceae (Sapindales), with a special focus on gynoecium structure and evolution. Botanical Journal of the Linnean Society 159: 499-571.

Baillon, H. 1878. The natural history of plants. Vol 5. L. Reeve \& Co., London.

Barbosa, D.C.A., Silva, Alves, J.L.H., Prazeres, S.M. \& Paiva, A.M.A. 1989. Dados fenológicos de 10 espécies arbóreas de uma área de Caatinga (Alagoinha- PE). Acta Botanica Brasilica 3: 109-117.

Barford, A.S. 1999. A new species of Tapirira (Anacardiaceae) from Ecuador. Novon 9 (4): 472-475.

Barkley, F.A. 1937. A monograph of the genus Rhus and its allies in North and Central America. Annals of the Missouri Botanical Garden 24:265-498.

Barkley, F.A. 1957a. Generic key to the Anacardiaceae. Lilloa 20(4): 255-265.

Barkley, F.A. 1957b. A study of Schinus L. Lloydia 28: 5-110.

Barkley, F.A. 1962a. Anacardiaceae: Rhoidea: Lithraea. Phytologia 8(7): 329-365.

Barkley, F.A. 1962b. Anacardiaceae: Rhoidea: Loxopterygium. Lilloa 25(2): 109-122.

Barkley, F.A. 1968. Anacardiaceae: Rhoidea: Astronium. Phytologia 16(2): 107-152.

Barrett, S.C.H. 2002. The evolution of plant sexual diversity. Nature reviews - Genetics 3: 214-284.

Barros, L.M. et al. 2002. Cajueiro. In: C.H. Bruckner (ed). Melhoramento de fruteiras tropicais. Viçosa: UFV, p.159-176.

Bawa, K.S. 1980. Evolution of dioecy in flowering plants. Annual Review of Ecology and Systematics 11: 15-39. 
Bawa, K.S. \& Beach, J.H. 1981. Evolution of sexual systems in flowering plants. Annals of the Missouri Botanical Garden 68(2): 254-274.

Bentham, G. \& Hooker, J.D. 1862. Genera Plantarum. Vol. 1. L. Reeve \& Co., London.

Biblioteca digital da Unicamp. Disponível em http://cutter.unicamp.br/. Acessado em 25/7/2011.

Biblioteca digital de teses e dissertações da Unesp. Disponível em http://unesp.br/cgb/conteudo.php?conteudo=562. Acessado em 25/7/2011.

Biblioteca digital de teses e dissertações da USP. Disponível em http://www.teses.usp.br/. Acessado em 24/7/2011.

Blackwell Jr., W.H. \& Dodson, C.H. 1968. Flora of Panama. Anacardiaceae. Annals of the Missouri Botanical Garden 54(3): 351-379.

Bremer, K., Bremer, B. \& Thulin, M. 1999. Introduction to phylogeny and systematic of flowering plants. 5 ed. Uppsala: Uppsala University.

Bridson, G.D.R. \& Smith, E.R. 1991. B-P-H Botanicum-PeriodicumHuntianum/supplementum. Carnegie Mellon University, Pittsburgh.

Brito, MC.W. \& Joly, C.A. (eds.). 1999. Biodiversidade do Estado de São Paulo, Brasil: síntese do conhecimento ao final do século XX: 7. Infra-estrutura para a Conservação da Biodiversidade. FAPESP. São Paulo.

Brown, R. 1818. Observations, systematical and geographical, on Professor Christian Smith's collection of plants from the vicinity of the River Congo. In J.H. Tuckey, Narrative of an expedition to explore the River Zaire. London, p. 420-485.

Brummitt, R.K. \& Powell, C.E. 1992. Authors of plant names. The Royal Botanical Garden, Kew, England. 732 p.

Cabrera, A.L. 1938. Revision de las Anacardiáceas Austroamericanas. Revista del Museo de La Plata NS 2: Bot. 6: 1-64.

Caetano, S., Prado, D., Pennington, R.T., Beck, S., Oliveira-Filho, A., Spichiger, R. \& Naciri, Y. 2008. The history of Seasonally Dry Tropical Forests in eastern South America: inferences from the genetic structure of the tree Astronium urundeuva (Anacardiaceae). Molecular Ecology 17: 3147-3159.

Caetano, S., Silveira, P., Spichiger, R. \& Naciri-Graven, Y. 2005. Identification of microsatellite markes in a neotropical seasonally dry forest tree, Astronium urundeuva (Anacardiaceae). Molecular Ecology Notes 5(1): 21-23.

Carmello-Guerreiro, S.M. 1999. Aspectos morfológicos e anatômicos da semente de aroeira (Myracrodruon urundeuva Fr. Allem. - Anacardiaceae), com notas sobre a paquicalaza. Revista brasileira de sementes 21(1): 222-228. 
Carmo, R.M. \& Franceschinelli, E.V. 2002. Polinização e biologia floral de Clusia arrudae Planchon \& Triana (Clusiaceae) na Serra da Calçada, município de Brumadinho, MG. Revista Brasileira de Botânica 25(3): 351-360.

Carvalho, M.P., Santana, D.G. \& Ranal, M.A. 2005. Emergência de plántulas de Anacardium humile A. St.-Hil. (Anacardiaceae) avaliada por meio de amostras pequeñas. Revista Brasileira de Botânica 28(3): 627-633.

Cesário, L.F. \& Gaglianone, M.C. 2008. Biologia floral e fenología reprodutiva de Schinus terebinthifolius Raddi (Anacardiaceae) em restinga do norte fluminense. Acta Botânica Brasilica 22(3): 828-833.

Chase, M.W., Soltis, D.E., Olmstead, R.G., Morgan, D., Les, D.H., Mishler, B.D., Duvall, M.R., Price, R.A., Hills, H.G., Quu, Y.L., Kron, K.A., Rettig, J.H., Conti, E., Palmer, J.D., Manhart, J.R., Sytsma, K.J., Michaels, H.J., Kress, W.J., Karol, K. G., Clark, W.D., Hedren, M., Gaut, B.S., Jansen, R.K., Kim, K.J., Wimpee, C.F., Smith, J.F., Furnier, G.R., Strauss, S.H., Xiang, Q.Y., Plunkett, G.M., Soltis, P. S., Swensen, S.M., Williams, S.E., Gadek, P.A., Quinn, C.J., Eguiarte, L.E., Golenberg, E., Learn, G.H., Graham, S.W., Barrett, S.C.H., Dayanandan, S. \& Albert, V.A. 1993. Phylogenetics of seed plants: na analysis of nucleotide sequences from the plastid gene rbcL. Annals of the Missouri Botanical Garden 80: 528-580.

Correia, S.J., David, J.P. \& David, J.M. 2006. Metabólitos secundários de espécies secundários Anacardiaceae. Química Nova 29(6): 1287-1300.

Crisp, M.D., Arroyo, M.T.K., Cook, L.G., Gandolfo, M.A., Jordan, G.J., McGlone, M.S., Weston, P.H., Westoby, M., Wilf, P. \& Linder, P. 2009. Philogenetic biome conservatism on a global scale. Nature 458: 754-756.

Cronquist, A. 1981. An integrated system of classification of flowering plants. New York: Columbia University Press.

Dahlgren, R.M.T. 1980. A revised system of classification of the angiosperms. botanical Journal of the Linnean Society 80: 91-124.

Dantas, H.G.R., Lima, H.C. Bohrer, C.B.A. 2009. Mapeamento da vegetação e da paisagem do município de Búzios, Rio de Janeiro, Brasil. Rodriguésia 60(1): 2538.

De Candolle, A.P. 1825. Prodomus Systematis Naturalis Regni Vegetabilis. Paris, vols. 1 e 2.

DIVA-GIS. A computer program for mapping, modeling, and analysis of biodiversity data. Disponível http://www.diva-gis.org. Acessado em 27/10/2011. 
Donoghue, M.J. 2008. A phylogenetic perspective on the distribution of plant diversity. Proceedings of the National Academy of Science of the United States of America 105: 11549-11555.

Engler, A. 1876. Anacardiaceae. In Martius, C.F.P. \& Eichler, A.G. (eds.) Flora brasiliensis. Fleischer, Leipzig, vol.12, pars 2, p. 367-418.

Engler, A. 1883. Anacardiaceae. In De Candolle, A. \& De Candolle, C. (eds.) Monographiae Phanerogamarum. Masson, Paris, vol. 4, p. 171-500.

Engler, A. 1896. Rutaceae, Simaroubaceae, Burseraceae, Anacardiaceae. In Engler, A. \& Plantl, K. (eds.) Die natürlichen Pflanzenfamilien. Wilhelm Englemann, Leipzig, Teil 3(5), p. 95-257.

Ellis, B., Daly, D.C., Hickey, L.J., Johnson, K.R., Mitchell, J.D., Wilf, P. \& Wing, S.L. 2009. Manual of leaf architecture. Cornell University Press, $190 \mathrm{p}$.

Ewell, J.J., Ojima, D.S., Karl, D.A., Debusk, W.F. 1982. Schinus in successional ecosystems of Everglades National Park. South Florida Research Report, T-676, Everglades National Park, Homestead, Florida.

Fenner, R., Betti, A.H., Mentz, L.A. \& Rates, S.M.K. 2006. Plantas utilizadas na medicina popular brasileira com potencial atividade antifúngica. Revista Brasileira de Ciências Farmacêuticas 42(3): 369-394.

Ferreti, A.R., Kageyama, P.Y., Arboez, G.F., Santos, J.D., Barros, M., Lorza, R.F. \& Oliveira, C. 1995. Classificação das espécies arbóreas em grupos ecológicos para revegetação no estado de São Paulo. Florestar Estatístico 3(7): 2-6.

Filer, D. 2000. BRAHMS - Botanical Research Arrangement for Herbarium Management System. Disponível on line.

Fleig. M. 1981. A família Anacardiaceae no Rio Grande do Sul, Brasil. Iheringia 28: 141-155.

Fleig, M. 1989. Anacardiáceas. In R. Reitz (ed.) Flora llustrada catarinense. Herbário Barbosa Rodrigues, Itajaí, 64 p.

Forzza, R.C., Baumgratz, J.F.A., Bicudo, C.E.M., Canhos, D.A.L., Carvalho Junior, A.A., Costa, A., Costa, D.P., Hopkins, M., Leitman, P., Lohmann, L.G., Lughadha, E.N., Maia, L.C., Martinelli, G., Menezes, M., Morim, M.P., Coelho, M.A.N., Peixoto, A.L., Pirani, J.R., Prado, J., Queiroz, L.P., Souza, S., Souza, V.C., Stehmann, J.R., Sylvestre, L.S., Walter, B.M.T. \& Zappi, D. 2010. Síntese da diversidade brasileira. In R.C. Forzza et al. (orgs.) Catálogo de plantas e fungos do Brasil. Rio de Janeiro: Jardim Botânico do Rio de Janeiro, v. 1, p. 2142.

Freeman, C.D. 1997. Sexual specialization and inbreeding avoidance in the evolution of dioecy. The Botanic Review 63(1): 65-92. 
Funk, V.A. 2006. Floras: a model for biodiversity studies or a thing of the past? Taxon 55(3): 581-588.

Gadek, P.A., Fernando, E.S., Quinn, C.J., Hoot, S.B., Terrazas, T., Sheahan, M.C. \& Chase, M.W. 1996. Sapindales: molecular delimitation and infraordinal groups. American Journal of Botany 83: 802-811.

Garcia, R.J.F \& Pirani, J.R. 2005. Análise florística, ecológica e fitogeográfica do Núcleo Curucutu, Parque Estadual da Serra do Mar (São Paulo, SP), com ênfase nos campos junto à cripta da Serra do Mar. Hoehnea 31(1): 1-48.

Geiger, J.H., Pratt, P.D., Wheeler, G.S., Williams, D.A. 2011. Hybrid vigor for the invasive exotic brazilian peppertree (Schinus terebinthifolis Raddi) in Florida. International Journal of Plant Sciences 172(5): 655-663.

Giulietti, A.M., Harley, R.M., Queiroz, L.P., Wanderley, M.G.L. \& Van De Berg, C. 2005. Biodiversidade e conservação das plantas no Brasil. Megadiversidade 1(1):5261.

Grant, V. 1995. Sexual selection in plants: pros and cons. Proceedings of the National of Sciences of the United States of America 92: 1247-1250.

Guimarães, M.C. 2003. Frugivoria por aves em Tapirira guianensis (Anacardiaceae) na zona urbana do município de Araruama, Estado do Rio de Janeiro, sudeste brasileiro. Atualidades Ornitológicas 116:12.

Hijmans, R.J., Guarino, L., Jarvis, A., O’Brien, R. \& Mathur, P. 2005. DIVA-GIS, version 5.2. A geographic information system for the analysis of biodiversity data. Manual. International Potato Center, Lima, Peru.

Hoogland, R.D. \& Reveal, J.L. 2005. Index nominum familiarum plantarum vascularium. The Botanical Review 71 (1/2): 1-291.

Hueck, K. 1972. As florestas da América do Sul: ecologia, composição e importância econômica. São Paulo: Polígono, 446 p.

Ibarra-Manríquez, G. \& Oyama, K. 1992. Ecological correlates of reproductive traits of mexican rain Forest trees. American Journal of Botany 79: 383-394.

Iponga, D.M., Milton, S.J. \& Richardson, D.M. 2009. Performance of seedlings of the invasive alien tree Schinus molle L. under indigenous and alien host trees in semi-arid savanna. Africa Journal of Ecology 48: 155-158.

IUCN. 2001. IUCN Red List categories and criteria. Version 3.1. IUCN, Gland, Switzerland \& Cambridge, U.K., 30 p.

Jadin, F. 1894. Reserches sur la structure et les affinités des Térébinthacées. Annales des Sciences Naturelles sér. 7, 19: 1-51.

Joly, A.B. 1950a. Conheça a Vegetação Brasileira. EDUSP, Polígono. São Paulo. 
Joly, A.B. 1950b. Estudo fitogeográfico dos campos de Butantã (São Paulo). Boletim da Faculdade de Ciências Filosofia, Ciências eLetras da Universidade de São Paulo, Botânica 8: 5-67.

Judd, W.S., Campbell, C.S., Kellog, E.A., Stevens, P.F. \& Donoghue, M.J. 2002. Plant Systematics. A phylogenetic approach. Ed. 2. Sinauer Associates, Sunderland. Jussieu, A.L. 1789. Genera plantarum secundum ordines naturalles disposita. Paris. Kageyama, P. \& Gandara, F.B. 2000. Revegetação de áreas ciliares. In Rodrigues, R.R., Leitão-Filho, H.F. (eds.) Matas ciliares: conservação e recuperação. Editora Universidade de São Paulo-USP, São Paulo, Brasil, p. 1-40.

Kawagoe, T. \& Suzuki, N. 2004.Cryptic dioecy in Actinidia polygama: A test of the pollinator attraction hypothesis. Canadian Journal of Botany 82: 214-218.

Krügel, M.M. \& Berh, E.R. 1998. Utilização dos frutos de Schinus terebinthifolius Raddi (Anacardiaceae) por aves no parque do Ingá, Maringá, Paraná. Revista Biociências (2): 47-56.

Lemos, R.P.L., Mota, M.C.S., Chagas, E.C.O. \& Silva, F.C. 2010. Checklist da Flora de Alagoas: Angiospermas. Instituto do Meio Ambiente de Alagoas, Herbário MAC, Maceió, 141p.

Lenza, E. \& Oliveira, P.E. 2005. Biologia reprodutiva de Tapirira guianensis Aubl. (Anacardiaceae), uma espécie dióica em mata de galeria do Triângulo Mineiro, Brasil. Revista Brasileira de Botânica 28(1): 179-190.

Lenzi, M. \& Orth, A.I. 2004. Fenologia reprodutiva, morfologia e biologia floral de Schinus terebinthifolius Raddi (Anacardiaceae) em restinga da llha de Santa Catarina, Brasil. Biotemas 17(2): 67-89.

Lindley, J. 1830. An introduction to the natural system of Botany: or, a systematic view of the organization, natural affinities, and geographical distribution of the whole vegetable kingdom; together with the uses of the most important species in medicine, the arts and rural or domestic economy. London: Logman, Rees, Orme, Brown, and Green.

Lloyd, D.G. \& Webb, C.J. 1977. Secondary sex characters in plants. Botanical Review 43(2): 177-216.

López-Naranjo, H.J. 1975. Estrutura morfológica de Anacardium humile St. Hil. (Anacardiaceae). Dissertação de mestrado, Universidade de São Paulo, São Paulo. 80 p.

López-Naranjo, H. 1977. Hábito de crescimento y estructura de las gemas de de Anacardium humile St.-Hil. Anacardiaceae. Revista Forestal. Venezolana 27: 159-172. 
Lorenzi, H. 2008. Árvores brasileiras. Manual de identificação e cultivo de plantas arbóreas nativas do Brasil. 5 ed. Instituto Plantarum, vol. 1. Nova Odessa, São Paulo, $384 \mathrm{p}$.

Lorenzi, H. \& Matos, F.J.A. 2002. Plantas medicinais no Brasil. Nativas e exóticas. Instituto Plantarum. Nova Odessa, São Paulo, 544 p.

Machado, I.C.S., Barros, L.M. \& Sampaio, V.S.B. 1997. Phenology of caatinga species at Serra Talhada, PE, Northeastern Brazil. Biotropica 29: 57-68.

Mamede, M.C.H.,Souza, V.C., Prado, J., Barros, F., Wanderley, M.G.L. \& Rando, J.G. 2007. Livro vermelho das espécies vegetais ameaçadas do Estado de São Paulo. Instituto de Botânica; Imprensa Oficial, São Paulo, 165 p.

Mantovani, W. 2003. A degradação dos biomas brasileiros. In W.C. Ribeiro (org.) Patrimônio ambiental brasileiro. Uspiana: Brasil 500 anos. Editora da Universidade de São Paulo. Imprensa Oficial do Estado de São Paulo. p. 367439.

Marchand, L. 1869. Histoire de L'ancien groupe des Térébinthacées. E. Martinet, Paris.

Mattick, Fr. 1934. Die gattung Astronium. Notizblatt des Botanischen Gartens und Museums zu Berlin-Dahlem 11(110): 991-1012.

Metzger, J.P. \& Rodrigues, R.R. 2008. Mapas-síntese. In Rodrigues, R.R.; Bononi, V.L.R. (org.) Diretrizes para a conservação e restauração da biodiversidade no Estado de São Paulo. p. 133-139.

Miller, A., young, D.A. \& Wen, J. 2001. Phylogeny and Biogeography of Rhus (Anacardiaceae) based on ITS sequence data. International Journal of Plant Sciences 162(6): 1401-1407.

Mitchell, J.D. 1990. The poisonous Anacardiaceae genera of the world. Advances in Economy Botany 8: 103-129.

Mitchell, J.D. 1993. Tapirira obtusa comb. nov. (Anacardiaceae). Novon 3(1): 66.

Mitchell, J.D. 1997. Anacardiaceae. In A.R.A. Görts-Van Rijn (eds.) Flora of the Guianas - Series A: Phanerogams 19(129): 1-79.

Mitchell, J.D. 2008. Anacardiaceae. In D.C. Daly \& M. Silveira (org.) Primeiro catálogo da flora do Acre, Brasil/ First catalogue of flora of Acre, Brazil. Rio Branco, AC: Edufac, p. 112-113.

Mitchell, J.D. \& Daly, D.C. 1991. Cyrtocarpa Kunth (Anacardiaceae) in South America. Annals of the Missouri Botanical Garden 78: 184-189.

Mitchell, J.D. \& Daly, D.C. 1993. A revision of Thyrsodium (Anacardiaceae). Brittonia 45(2): 115-129.

Mitchell, J.D. \& Daly, D.C. 1998. The "Tortoise's cajá" - a new species of Spondias (Anacardiaceae) from Southwestern Amazonia. Brittonia 50(4): 447-451. 
Mitchell, J.D., Daly, D.C., Pell, S.K. \& Randrianasolo, A. 2006. Poupartiopsis gen. nov. and its context in Anacardiaceae classification. Systematic Botany 31(2): 337348.

Mitchell, J.D. \& Mori, S.A. 1987. The Cashew and Its Relatives (Anacardium: Anacardiaceae). Memoirs of the New York Botanical Garden 42: 1-76.

Mittermeier, R.A., Fonseca, G.A.B., Rylands, A.B. \& Brandon, K. 2005. Uma breve história da conservação da biodiversidade no Brasil. Megadiversidade 1(1): 1421.

Moraes, A.J.M. 1874. A vida e a morte do Exm. Sr. Conselheiro Francisco Freire Allemão Cysneiro escripta, em vista das notas por elle proprio fornecidas. Typographia de Quirino F. do Espirito Santo, Rio de Janeiro.

Morais, R.C.J. 2005. Nos verdes campos da ciência: a trajetória acadêmica do médico e botânico brasileiro Francisco Freire-Allemão (1797-1874). Dissertação de mestrado. Fiocruz, Rio de Janeiro.

Morrone, J.J. 2002. Biogeographic regions under track and cladistic scrutiny. Journal of Biogeography. 29: 149-152.

Muñoz, J.D. 1990. Flora Del Paraguay. St. Louis, MO: Missouri Botanical Garden, p. 784.

Muñoz, J.D. 2000. 153. Anacardiaceae. In A.T. Hunkizer (ed.) Flora Fanerogamica Argentina. Proflora (Conicet), Cordoba, fasc. 65, p.1-28.

Myers, N., Mittermeier, R.A., Mittermeier, C.G., Fonseca, G.A.B. \& Kent, J. 2000. Biodiversity hotspots for conservation priorities. Nature 403(24): 853-858.

Nalon, M.A., Mattos, I.F.A. \& Franco, G.A.D.C. 2008. Meio físico e aspectos da fragmentação da vegetação. In Rodrigues, R.R.; Bononi, V.L.R. (org.) Diretrizes para a conservação e restauração da biodiversidade no Estado de São Paulo. p. 16-21.

Nel, J.L., Richardson, D.M., Rouget, M., Mgidi, T.N., Mdzeke, N., Le Maitre, D.C., Wilgen, B.W., Schonegevel, L., Henderson, L. \& Neser, S. 2004. A proposed classification of invasive alien plant species in South Africa: towards prioritizing species and areas for management action. South Africa Journal of Science 100: 53-64.

Nie, Z., Sun, H., Meng, Y. \& Wen, J. 2009. Phylogenetic analysis of Toxicodendron (Anacardiaceae) and its biogeographic implications on the evolution of north temperate and tropical intercontinental disjunctions. Journal of Systematics and Evolution 47(5): 416-430. 
Obeso, J.R. \& Retuerto, R. 2002. Dimorfismo sexual em el acebo, Ilex aquifolium: coste de la reproducción, selección sexual o diferenciación fisiológica? Revista chilena de história natural 75(1): 67-77.

Oliveira, J.M.S. \& Mariath, J.E.A. 2001. Anther and pollen development in Anacardium occidentale (Anacardiaceae) clone CP76. Phytomorphology 51: 91-100.

Oliveira-Filho, A.T. \& Ratter, J.A. 1995. A study of the origino $f$ Central Brazilian Forests by the analysis of plant species distribution patterns. Edinburg Journal of Botany 52(2): 141-194.

Pell, S.K. 2004. Molecular systematics of the cashew family (Anacardiaceae). Ph.D. dissertation. Baton Rouge: Lousiana State University.

Pell, S.K., Mitchell, J.D., Miller, A.J. \& Lobova, T.A. 2011. Anacardiaceae. In K. Kubitzki (ed.) The families and genera of vascular plants. X. Flowering plants. Eudicots. Sapindales, Curcubitales, Myrtales. Springer, Berlin, p. 7-50.

Pell, S.K., Mitchell, J.D., Lowry, P.P., Randrianasolo, A. \& Urbatsch, L.E. 2008. Phylogenetic split of Malagasy and African taxa of Protorhus and Rhus (Anacardiaceae) based on cpDNA trnL-trnF and nrDNA ETS and ITS sequence data. Systematic Botany 33: 375-383.

Pennington, T.D., Reynel, G. \& Daza, A. 2004a. Ilustrated Guide to the Trees of Peru. $\mathrm{DH}$ (David Hunt), Sherborne.

Pennington, R. T., Lavin, M., Prado, D. E., Pendry C. A., Pell, S. K. \& Butterworth, C. A. 2004b. Historical climate change and speciation: neotropical seasonally dry forest plants show patterns of both Tertiary and Quaternary diversification. Philosophical Transactions of The Royal Society - Biological Sciences 359: 515538.

Pillar, V.D. 2003. Dinâmica da expansão florestal em mosaicos de floresta e campos no sul do Brasil. In V. Claudino-Sales (ed.) Ecossistemas brasileiros: manejo e conservação. Fortaleza: Expressão, p. 209-216.

Pillar, V.D. 2006. Estado atual e desafios para a conservação dos campos. Porto Alegre: UFRGS. Relatório de seminário, 27/3/2006.

Pillar, V.D. \& Quadros, F.L.F. 1997. Grassland-forest boundaries in southern Brazil. Coenoses, Gorizia 12 (2-3): 119-126.

Pirani, J.R. 1981. Flora Fanerogâmica da Reserva do Parque Estadual das Fontes do Ipiranga (São Paulo, Brasil). Hoehnea 9: 108-110.

Pirani, J.R. 1987. Flora da Serra do Cipó, Minas Gerais: Anacardiaceae. Boletim de Botânica da Universidade de São Paulo 9: 199-209.

Pirani, J.R. 2002. Anacardiaceae. In Barros et al. (eds.) Flora Fanerogâmica da llha do Cardoso. Instituto de Botânica, São Paulo, vol. 9, p. 45-50. 
Pirani, J.R. 2003. Flora de Grão-Mogol, Minas Gerais: Anacardiaceae. Boletim de Botânica da Universidade de São Paulo 21(1): 61-65.

Pirani, J.R. 2006. Sistemática: Tendências e Desenvolvimento, incluindo impedimentos para o avanço do conhecimento da área. Disponível em: www.cria.org.br/ cgee/ documentos/ PiraniTextoSistematica.doc. Acesso em 23/09/2008.

Prado, D.E. \& Gibbs, P.E. 1993. Patterns of species distribution in the dry seasonal forests of South America. Annals of the Missouri Botanical Garden 80: 902-927.

Primack, R.B. 1985. Longevity of individual flowers. Annual Review of Ecology and Systematics 16: 15-37.

Radford, A.E. 1986. Fundamentals of plant systematics. Harper \& Row. New York.

Ramos, M.C. 2009. Ecologia da polinização de taperebá (Spondias mombin L., Anacardiaceae) em área de floresta secundária no município de Santo Antônio do Tauá, Pará, Brasil. Dissertação de mestrado. Universidade Federal do Pará.

Reis, A.M.M. \& Grattapaglia, D. 2004. RAPD variation in a germoplasm collection of Myracrodruon urundeuva (Anacardiaceae), an endangered tropical tree: Recommendation for conservation. Genetic Resources and Crop Evolution 51(5): 529-538.

Renner, S.S. \& Ricklefs, R.E. 1995. Dioecy and its correlates. American Journal of Botany 82: 596-606.

Ribeiro, J.E.L.S. \& Mitchell, J.D. 1999. Anacardiaceae. In J.E.L.S. Ribeiro (eds.) Flora da Reserva Ducke - Guia de identificação das plantas vasculares de uma floresta de terra-firme na Amazônia Central. INPA-DFID. Manaus, p. 544-546.

Rottenberg, A. 1998. Sex ratio and gender stability in the dioecious plant of Israel. Botanical Journal of the Linnean Society 128: 137-148.

Sabbi, L.B.C., Ângelo, A.C. \& Boeger, M.R. 2010. Influência da luminosidade nos aspectos morfoanatômicos e fisiológicos de folhas de Schinus terebinthifolius Raddi (Anacardiaceae) implantadas em duas áreas com diferentes graus de sucessão, nas margens do Reservatório Iraí, Paraná, Brasil. Iheringia, Série Botânica 65(2): 171-181.

Santin, D.A. 1989. Revisão taxonômica do gênero Astronium Jacq. e revalidação do gênero Myracrodruon Fr. Allemão. Dissertação de mestrado, Universidade Estadual de Campinas, Campinas. 178 p.

Santin, D.A. \& Leitão-Filho, H.F. 1991. Restabelecimento e revisão taxonômica do gênero Myracrodruon Freire Allemão (Anacardiaceae). Revista Brasileira de Botânica 14: 133-145.

Santos, C.C. 2004. A família Anacardiaceae Lindl. no semiárido do Estado da Bahia, Brasil. Dissertação de mestrado. Universidade Estadual de Feira de Santana. 
Savolainen, V., Chase, M.W., Hoot, S.B., Morton, C.M., Soltis, D.E., Bayer, C., Fay, M.F., Bruijn, A.Y., Sullivan, S. \& Qui, Y.L. 2000a. Phylogenetics of flowering plants based on combined analysis of plastid atpB and rbcL gene sequences. Systematic Biology 49: 306-362.

Savolainen, V., Fay, M.F., Albach, D.C., Backlung, A., van der Bank, M., Cameron, K.M., Johnson, S.A., Lledó, M.D., Soltis, D.E., Soltis, P.S., Weston, P., Whitten, W.M., Wurdack, K.J., Chase, M.W. 2000b. Phylogeny of the eudicots: a nearly complete familial analysis based on $r b c L$ gene sequences. Kew Bulletin. 55: 257309.

Scaramuzza, C.A.M. 2007. Flora e ecologia dos campos de Itararé, São Paulo, Brasil. Tese de doutorado. Universidade de São Paulo.

Schaefer, H.M. \& Ruxton, G. 2009. Deception in plants: mimicry or percentual exploitation? Trends in Ecology and Evolution 24(2): 676-685.

Schmid, R. 1978. Reproductive anatomy of Actinidia chinensis (Actinidiaceae). Botanische Jahrbuch Systematic 100: 149-195.

Schmitz, D.C., Simberloff, D., Hofstetter, R.H., Haller, W., Sutton, D. 1997. The ecological impact of nonindigenous species. In D. Simberloff, D.C., Schmitz, T.C., Brown (eds) Strangers in Paradise: Impact and Management of Nonindigenous species in Florida. Island Press, Washington, D.C., p. 9-61.

Scholz, H. 1964. Reihe Rutales, Reihe Sapindales. In: A. Engler's Syllabus der Pflanzenfamilien. 12. Gebrüder Borntraeger, Berlin.

Scudeller, V.V., Martins, F.R. \& Shepherd, G.J. 2001. Distribution and abundance of arboreal species in the atlantic ombrophilous dense forest in Southeastern Brazil. Plant Ecology 152: 185-199.

Secretaria do Meio Ambiente, 2008. Resolução SMA 08. Lista oficial das espécies da flora do Estado de São Paulo ameaçadas de extinção. Disponível em http://www.ibot.sp.gov.br/legislacao/resolucao_SMA08-31.1.2008.pdf. Acesso em 28/10/2008.

Silva-Junior, M.C., Felfili, J.M., Nogueira, P.E. \& Rezende, A. V. 1998. Análise florística das matas de galeria no Distrito Federal. In: J.F. RIBEIRO (org.). Cerrado: matas de galeria. Planaltina, DF: Embrapa, p. 143-185.

Silva-Luz, C.L. \& Pirani, J.R. 2010. Anacardiaceae. In R.C. Forzza et al. (org.) Catálogo de plantas e fungos do Brasil. Rio de Janeiro: Jardim Botânico do Rio de Janeiro, v. 1, p. 599-602.

Souza, V.C. \& Lorenzi, H. 2005. Botanica Sistemática. ilustrado para identificação das famílias de Angiospermas da flora brasileira, baseado em APG II. Instituto Plantarum de Estudos da Flora LTDA, Nova Odessa. 
Souza, V.C., Mamede, M.C.H., Cordeiro, I., Prado, J., Barros, F., Wanderley, M.G.L., Kageyama, P.Y., Ceccantini, G. \& Rando, J.G. 2007. Critérios uilizados na elaboração da Lista oficial de espécies da flora ameaçadas de extinção no Estado de São Paulo. In M.C.H. Mamede, V.C. Souza, J. Prado, F. Barros, M.G.L. Wanderley \& J.G. Rando (Org.) Livro vermelho das espécies vegetais ameaçadas do Estado de São Paulo. 1 ed. São Paulo: Instituto de Botânica, p. 15-20.

Stafleu, F.A. \& Cowan, R.S. 1976. Taxonomic Literature. 2 ed. Vols. 1-7. Utrecht: Bohn, Scheltema \& Holkema.

Steibel, P.E. \& Troiani, H.O. 2008. La identidade de Schinus fasciculatus var. arenicola y rehabilitación de $S$. sinuatus (Anacardiaceae). Boletín de la Sociedad Argentina de Botánica 43(1-2): 157-166.

Stevens, P.F. Versão 9, junho de 2008. Angiosperm Phylogeny Website. Disponível em http://www.mobot.org/MOBOT/research/APWeb/. Acessado em 17.10.2011.

Takhtajan, A. 1986. The Floristic Regions of the World. Academy of Sciences of the U.S.S.R.. Leningrad. [em Russo]

Takhtajan, A. 1987. Systema magnoliophytorum. Leningrad: Nauka. [em Russo]

Takhtajan, A. 1997. Diversity and classification of flowering plants. New York: Columbia University Press.

Terrazas, T. 1994. Wood anatomy of the Anacardiaceae: ecological and phylogenetic interpretation. Ph.D. dissertation. Chapel Hill, NC: University of North Carolina.

Terrazas, T. 1995. Anatomía sistemática de la familia Anacardiaceae en México. I. La corteza de Tapirira Aublet. Boletin de la Sociedad Botanica de México 57: 103112.

Terrazas, T. 1999. Anatomía de la madera de Anacardiaceae con énfasis en los géneros americanos. Boletin de la Sociedad Botanica de México 64:103-109.

Terrazas, T. \& Wendt, T. 1995. Systematic wood anatomy of the genus Tapirira Aublet (Anacardiaceae) - a numerical approach. Brittonia 47(2): 109-129.

The International Plant Names Index. 2008. Disponível em http://www.ipni.org. Acessado em 10.9.2011.

Tropicos.org. Missouri Botanical Garden. Disponível em http://www.tropicos.org. Acessado em 23.8.2011.

Ururahy, J. C.; Collares, J. E. R. \& Santos, M. M. 1987. Nota sobre uma formação fisionômica-ecológica disjunta da estepe nordestina na área do pontal de Cabo Frio, RJ. Revista Brasileira de Geografia 49: 25-29.

Usteri, A. 1911. Flora der Umgeburg von Stadt São Paulo in Brasilien. Jena: Gustav Fischer. 
Varela, F. J. \& Novara, L.J. 2007. Anacardiaceae Lindl. Flora del Valle de Lerma. Aportes Botanicos Salta, Ser. Flora 8(6): 1-28.

Veloso, H.P., Rangel Filho, A.L.R. \& Lima, J.C.A. 1991. Classificação da vegetação brasileira, adaptada a um sistema universal. IBGE, Rio de Janeiro.

Villa, A.S., Sühs, R.B. \& Köhler, A. 2010. Entomofauna associated to the floration of Schinus terebinthifolius Raddi (Anacardiaceae) in the Rio Grande do Sul state, Brazil. Bioscience Journal 26: 956-965.

Wanderley, M.G.L., Shepherd, G.J. \& Giulietti, A.M. (coord.). 2001. Flora Fanerogâmica do Estado de São Paulo. vol. 1. FAPESP, HUCITEC, São Paulo.

Wanderley, M.G.L., Shepherd, G.J. \& Giulietti, A.M. (coord.). 2006. Flora Fanerogâmica do Estado de São Paulo. vol. 4. FAPESP, HUCITEC, São Paulo.

Wanderley, M.G.L., Shepherd, G.J. \& Giulietti, A.M. (coord.). 2009. Flora Fanerogâmica do Estado de São Paulo. vol. 6. FAPESP, HUCITEC, São Paulo.

Wannan, B.S. 2006. Analysis of generic relantionships in Anacardiaceae. Blumea 51: 165-195.

Wannan, B.S. \& Quinn, C.J. 1990. Pericarp structure and generic affinities in the Anacardiaceae. Botanical Journal of the Linnean Society 103: 225-252.

Wannan, B.S. \& Quinn, C.J. 1991. Floral structure and evolution in the Anacardiaceae. Botanical Journal of the Linnean Society 107: 349-385.

Warming, E. 1908. Lagoa Santa. Imprensa Official do Estado de Minas Gerais. Belo Horizonte.

Weberling F. 1989. Morphology of flowers and inflorescences. Cambridge: Cambridge University Press.

Wendt, T. \& Mitchell, J.D. 1995. A new species of Tapirira (Anacardiaceae) from the Isthmus of Tehuantepec, Mexico. Brittonia 47(2): 101-108.

Wiens, J.J. \& Donoghue, M.J. 2004. Historical biogeography, ecology, and species richness. Trends in Ecology \& Evolution 19:639-644.

Williams, D.A., Overholt, W.A., Cuda, J.P., Hughers, C.R. 2005. Chloroplast and microsatellite DNA diversities reveal the introduction history of Brazilian peppertree (Schinus terebinthifolius) in Florida. Molecular Ecology 14: 36433656.

Xavier, A.F., Bolzani, B.M. \& Jordão, S. 2008. Unidades de conservação da natureza no Estado de São Paulo. In Rodrigues, R.R.; Bononi, V.L.R. (org.) Diretrizes para a conservação e restauração da biodiversidade no Estado de São Paulo. p. 2442. 
Yi, T., Miller, A.J. \& Wen J. 2007. Phylogeny of Rhus (Anacardiaceae) based on sequences of nuclear Nia-i3 intron and Chloroplast TrnC-TrnD. Systematic Botany 32(2): 379-391.

Yi, T., Wen, J., Golan-Goldhirsh, A. \& Parfitt, D. 2008. Phylogenetics and reticulate evolution in Pistacia (Anacardiaceae). American Journal of Botany 95(2): 241251.

Zapata, T.R. \& Arroyo, M.T.K. 1978. Plant reproductive ecology of a secondary deciduous tropical forest in Venezuela. Biotropica 10: 221-230.

Zenni, R.D. \& Ziller, S.R. 2001. An overview of invasive plants in Brazil. Revista Brasileira de Botânica 34(3): 431-446. 